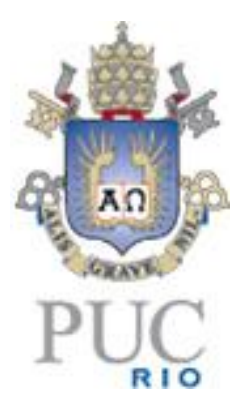

Tamires Magalhães de Mello

Gestão de Portfólio de Itens de Alavancagem para

Sustentabilidade em Contratações - Estudo de Caso em uma Empresa de Mineração

Dissertação de Mestrado

Dissertação apresentada como requisito parcial para obtenção do grau de Mestre (opção profissional) pelo Programa de PósGraduação do Departamento de Engenharia Industrial da PUC-Rio.

Orientador: Prof. Dra. Adriana Leiras

Rio de Janeiro Setembro de 2014 
Tamires Magalhães de Mello

\section{Gestão de Portfólio de Itens de Alavancagem para Sustentabilidade em Contratações - Estudo de Caso em uma Empresa de Mineração}

Dissertação apresentada como requisito parcial para obtenção do grau de Mestre (opção profissional) pelo Programa de Pós-Graduação em Engenharia de Produção do Departamento de Engenharia Industrial da PUC-Rio. Aprovada pela Comissão Examinadora abaixo assinada.

Prof. Adriana Leiras

Orientadora

Departamento de Engenharia Industrial - PUC-Rio

Prof. Osvaldo Quelhas

Departamento de Engenharia Industrial - UFF

Prof. Andre Lacombe

Departamento de Administração - IAG PUC-Rio

Prof. José Eugênio Leal

Coordenador Setorial do Centro Técnico Científico - PUC-Rio

Rio de Janeiro, 04 de Setembro de 2014. 
Todos os direitos reservados. É proibida a reprodução total ou parcial do trabalho sem autorização da universidade, do autor e do orientador.

\section{Tamires Magalhães de Mello}

Graduou-se em Engenharia de Produção na Pontifícia Universidade Católica do Rio de Janeiro (PUC-Rio) em 2011. Após passagem profissional pela área de Private Equity na Nova Gestão de Investimentos, trabalha hoje na Vale, onde atua como Gestora de Categoria de Movimentação Interna sendo responsável pelo Planejamento e Execução de processos da área de compras.

Ficha Catalográfica

Mello, Tamires Magalhães de

Gestão de Portfólio de Itens de Alavancagem para Sustentabilidade em Contratações - Estudo de Caso em uma Empresa de Mineração/Tamires Magalhães de Mello; orientador: Adriana Leiras. - 2014.

111 f. : il. (color.) ; $30 \mathrm{~cm}$

Dissertação (mestrado)-Pontifícia Universidade Católica do Rio de Janeiro, Departamento de Engenharia Industrial, 2014.

Inclui bibliografia

1. Engenharia Industrial - Teses. 2. Suprimentos. 3. Compras; 4. Sustentabilidade. 5. Terceirização. 6. Modelo de portfólio. I. Leiras, Adriana. II. Pontifícia Universidade Católica do Rio de Janeiro. Departamento de Engenharia Industrial. III. Gestão de Portfólio de Itens de Alavancagem para Sustentabilidade em Contratações - Estudo de Caso em uma Empresa de Mineração.

CDD: 658.5 


\section{Agradecimentos}

Aos meus pais e ao meu irmão, por sempre me apoiarem em todos os momentos da minha vida.

Aos meus amigos, por mostrarem o verdadeiro sentido da palavra amizade.

A Pontifícia Universidade Católica do Rio de Janeiro, pela oportunidade concedida para a realização do Mestrado Profissional em Logística.

A todos os amigos e familiares que de uma forma ou de outra me estimularam ou me ajudaram. 


\section{Resumo}

Mello, Tamires Magalhães de; Leiras, Adriana. Gestão de Portfólio de Itens de Alavancagem para Sustentabilidade em Contratações - Estudo de Caso em uma Empresa de Mineração. Rio de Janeiro, 2014. 111 p. Dissertação de Mestrado - Departamento de Engenharia Industrial, Pontifícia Universidade Católica do Rio de Janeiro.

A crescente competitividade tem induzido muitas organizações a reestruturar seus processos, tornando-os mais dinâmicos e enxutos, exigindo maior flexibilidade, melhor qualidade e menor custo. Com isso, os temas sustentabilidade e compras têm apresentado crescente interesse acadêmico nos últimos anos. Em relação à sustentabilidade, sua importância se deve principalmente à atenção despertada face às mudanças climáticas causadas pela ação do Homem no meio ambiente. Devido a isso, as empresas passam a se preocupar não apenas com os ganhos, mas também com os fatores ambientais, econômicos e sociais. Em relação a Compras, esta atividade assumiu importante posição estratégica nos últimos anos dentro das empresas principalmente quando se percebeu quanto que o gasto com compras representa no valor do produto final. Aliado a estas questões, percebe-se na literatura poucos estudos referentes ao conceito de sustentabilidade dentro de compras. Este conceito é importante, já que, quanto mais sustentável a empresa for em seus processos, maior sua vantagem competitiva e chance de sobrevivência no mercado. Esta dissertação consiste na identificação dos fatores de sustentabilidade que são tangíveis e necessários ao processo de compras para que ele seja considerado sustentável. A principal contribuição deste estudo é a aplicação e a avaliação de um modelo de portfólio de compras voltado para sustentabilidade. A pergunta central que se objetiva responder é "como os elementos da sustentabilidade devem ser aplicados para a obtenção de uma Compra Sustentável?" e é complementada através de estudo de caso para diagnóstico de uma categoria de compras, alocada no quadrante alavancagem da matriz de Kraljic, de uma empresa do setor de mineração. $\mathrm{O}$ ponto de partida é a identificação dos fatores que caracterizam um processo de contratação como sustentável. Para isso, uma extensa revisão bibliográfica foi realizada. Após a aplicação do modelo, conclui-se que a categoria analisada é classificada como Commodity Estratégica no modelo de Pagell et al.(2010) e, como principal característica pode-se citar o risco de fornecimento que o comprador leva de baixo para alto, devido a necessidade de se investir no relacionamento com os fornecedores para mitigar riscos ao Tripple Bottom Line.

\section{Palavras Chave}

Suprimentos; Compras; Sustentabilidade; Terceirização; Modelo de Portfólio. 


\section{Abstract}

Mello, Tamires Magalhães de; Leiras, Adriana. Portfolio management of leverage items for Sustainability in Signings - Case study on a Mining Company. Rio de Janeiro, 2013. 111p. MSc. Dissertation - Departamento de Engenharia Industrial, Pontifícia Universidade Católica do Rio de Janeiro

The growing global competitiveness has led many organizations to restructure their processes, making them more lean and dynamic, requiring greater flexibility, better quality and lower cost. With that, the sustainability themes and purchases have shown increasing academic interest in recent years. With regard to sustainability, its importance is mainly due to attention aroused face climate change caused by predation of Man on the environment. Because of this, companies are worrying not only with gains, but also with the environmental, economic and social factors. In respect of Purchases, this activity has assumed important strategic position within companies in recent years, especially when the companies noted how much that is spending with purchases and what is the percentage that represents this value in the final product. Allied to these issues, there are very few studies in the literature related to the concept of sustainability within the purchasing process. This concept is important, since the more sustainable the company is in its processes, the greater your competitive advantage.This dissertation presents the identification of sustainability factors which are tangible and required for the purchasing process for it to be considered sustainable. The main contribution of this study is the implementation and evaluation of a model portfolio of purchases aimed at sustainability. The central question that aims to answer is " How do the sustainability factors must be applied to obtaining a sustainable Purchase ?" and is supplemented using a case study for diagnosis of a shopping category of a company in the mining sector, allocated on the Kraljic matrix leverage quadrant. The starting point is the identification of the factors that characterize a contracting process as sustainable. For this, an extensive literature review was conducted. After applying the template, it appears that the category analyzed is classified as a Strategic Commodity in Pagell model et al. (2010) and as main feature can cite the delivery risk the buyer takes from low to high due to the need to invest in the relationship with suppliers to mitigate risks to the Triple Bottom Line.

\section{Keywords}

Supplies; Purchases; Sustainability; Outsourcing; Portfolio Model. 


\section{Sumário}

1. INTRODUÇÃO 12

1.1 OBJETIVOS 15

1.2 DELIMITAÇÃO 16

1.3 ESTRUTURA DA DISSERTAÇÃO 17

2FUNDAMENTAÇÃO TEÓRICA 18

2.1 COMPRAS 18

2.1.1EVOLUÇÃO DO CONCEITO DE COMPRAS 19

2.1.2COMPRA ESTRATÉGICA 21

2.1.3PROCESSO DE COMPRA ESTRATÉGICA 23

2.1.4MODELO DE KRALJIC PARA GESTÃO ESTRATÉGICA 26

2.2 SUSTENTABILIDADE 36

2.2.1EVOLUÇÃO DO CONCEITO 38

2.2.2DIMENSÕES DA SUSTENTABILIDADE 40

2.2.3DESENVOLVIMENTO SUSTENTÁVEL E ESTRATÉGIA EMPRESARIAL 43

2.3 SUSTENTABILIDADE EM COMPRAS

2.3.1DEFINIÇÃO $\quad 45$

2.3.2BENEFÍCIOS DAS COMPRAS SUSTENTÁVEIS 48

2.3.3MODELO DE PORTFÓLIO COM A DIMENSÃO DE SUSTENTABILIDADE 49

3. METODOLOGIA DE PESQUISA 56

4. CONTEXTUALIZAÇÃO DO ESTUDO DE CASO 61

4.1 Panorama do Setor de MineraçÃo no Brasil 61

4.2 APRESENTAÇÃO DA EMPRESA $\quad 64$

4.3 CATEgoRIA DE MOVIMENTAÇÃo INTERNA 65

5. ESTUDO DE CASO 67

5.1 VALIDAÇÃO dA ApLICAÇÃO dO MODELO dE KRALJIC (1953) 67

5.2 Modelo de PAGELL ET AL. (2010) 72

6. CONCLUSÕES E RECOMENDAÇÕES 84

6.1 RECOMENDAÇÕES PARA ESTUdOS FutuROS 87

REFERÊNCIAS BIBLIOGRÁFICAS $\quad 89$

ANEXO I: MODELO DE OLSEN \& ELLRAM (1997) 100

ANEXO 2: MÉTODO DE NARASIMHAN (1983) 105

ANEXO 3- MODELO DE QUESTIONÁRIO 109 


\section{Lista de Tabelas}

Tabela 1- Diferenças entre Processos de Compras

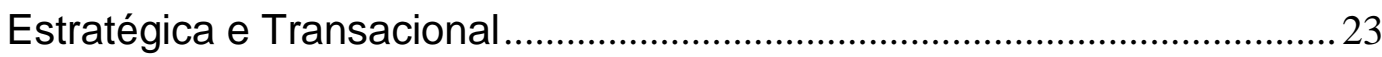

Tabela 2- Atividades e Informações Demandadas

por Cada Tipo de Item

Tabela 3- Fatores para Avaliação da Força do Comprador e do

Fornecedor

Tabela 4- Implicações das Posições Estratégicas Escolhidas

Tabela 5-Três Dimensões do Desenvolvimento Sustentável:

Principais Pontos

Tabela 6- Dimensões das Compras Sustentáveis ............................................ 47

Tabela 7- Benefícios das Compras Sustentáveis............................................... 48

Tabela 8- Prática de Continuidade da Base de Suprimentos.........................50

Tabela 9- Categorias da Matriz de Portfólios Revisada ...................................53

Tabela 10- Premissas para Avaliação da Complexidade do Mercado

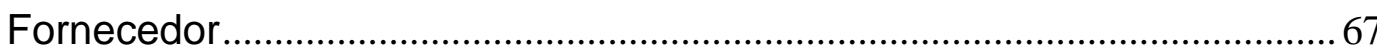

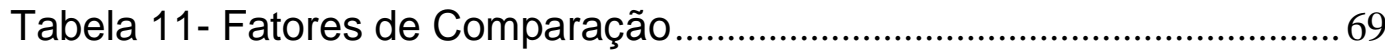

Tabela 12- Resultado da Aplicação do Método de Narasimhan(1983)

para os Itens de Complexidade do Mercado Fornecedor

Tabela 13- Escala Determinada na Pesquisa para os Valores de

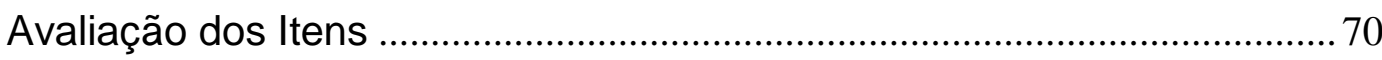

Tabela 14- Resultado da Ponderação para o Eixo Horizontal da

Matriz de Kraljic Utilizando o Método de Narasimhan (1983) .70

Tabela 15- Premissas para Avaliação do Eixo de Importância das

Compras.

Tabela 16- Resultado da Aplicação do Método de Narasimhan(1983)

para os Itens de Importância das Compras................................................... 72

Tabela 17- Resultado da Ponderação para o Eixo Vertical da

Matriz de Kraljic Utilizando o Método de Narasimhan (1983) ........................ 72

Tabela 18- Score para Classificação dos Itens ................................................ 72

Tabela 19- Componentes do Tripple Bottom Line Utilizados no

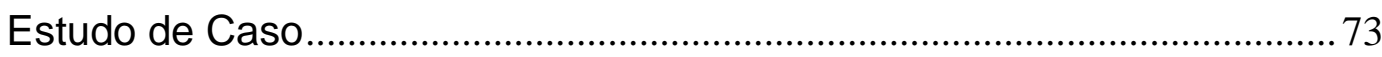

Tabela 20- Análise da Dimensão Ambiental ................................................. 74

Tabela 21- Escala de Avaliação ......................................................................... 75 
Tabela 22- Resultado da Aplicação do Método de Narasimhan (1983) para os Itens que Compõem o Pilar de Impacto Ambiental 75

Tabela 23- Escala Determinada na Pesquisa para os Valores de Avaliação dos Itens 75

Tabela 24- Resultado da Ponderação Total para Avaliação do

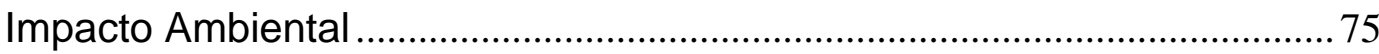

Tabela 25- Análise da Dimensão Social .......................................................... 76

Tabela 26- Resultado da Aplicação do Método de Narasimhan(1983) para os Itens que Compõem o Pilar de Impacto Social. .................................. 77

Tabela 27- Resultado da Ponderação Total para Avaliação do

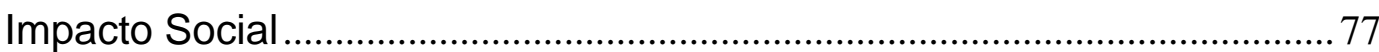

Tabela 28- Análise da Dimensão Econômica .................................................78

Tabela 29- Resultado da Aplicação do Método de Narasimhan(1983)

para os Itens que Compõem o Pilar de Impacto Econômico .......................... 78

Tabela 30- Resultado da Ponderação Total para Avaliação do Impacto

Econômico

Tabela 31- Resultado do Score Apontado pelo Método de

Narasimhan (1983)

Tabela 32- Premissas Acrescentadas para Avaliação do Risco de

Fornecimento 80

Tabela 33- Resultado da Aplicação do Método de Narasimhan(1983)

para os Itens que Compõem o Eixo de Risco de Fornecimento 81

Tabela 34- Resultado da Ponderação Total para Avaliação do Eixo de Risco de Fornecimento

Tabela 35- Escala Determinada na Pesquisa para os Valores de Avaliação dos Itens 


\section{Lista de Figuras}

Figura 1- Interação Entre os Desenvolvimentos Econômico,

Social e Ambiental. 13

Figura 2- Processo de Compras Estratégicas …………………………........24

Figura 3- Modelo de Análise de Portfólio........................................................2 29

Figura 4- Posicionamento Estratégico do Poder de Compra ..........................34

Figura 5- Matriz de Portfólio de Compras Sustentáveis ..................................51

Figura 6- Matriz de Inclusão da Sustentabilidade nas Categorias

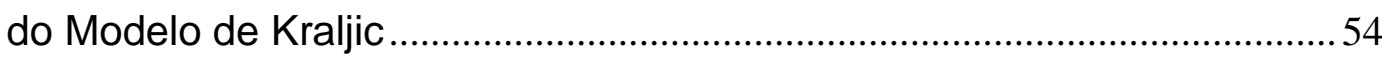

Figura 7- Perfil Profissional dos Integrantes da Categoria de

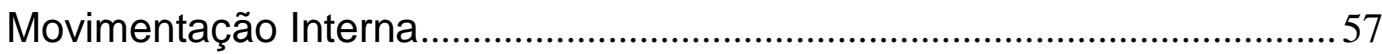

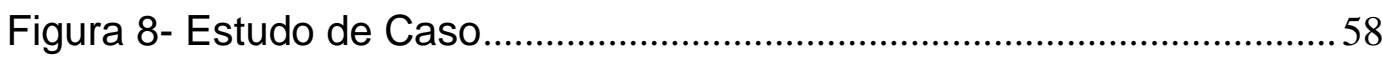

Figura 9- Dados Sobre o Setor de Mineração do Brasil................................... 62

Figura 10- Componentes Adicionados a Análise de Risco de

Fornecimento Utilizados no Estudo de Caso ...................................................... 80

Figura 11- Matriz Adaptada de Kraljic ......................................................... 100

Figura 12- Análise do Relacionamento com o Fornecedor........................... 103

Figura 13- Hierarquia dos Fatores do Eixo Vertical ..................................... 105

Figura 14- Cálculo dos Pesos dos Fatores ................................................... 106

Figura 15- llustração do Cálculo dos Pesos de Cada Fator ......................... 106

Figura 16- Ilustração do Cálculo do Score a Partir dos Pesos e

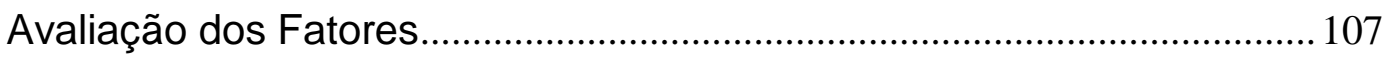




\section{Lista de Siglas e Abreviações}

BCSD Portugal- Conselho Empresarial para o Desenvolvimento

Sustentável

B2B- Business to Business

CEOs - Chief Executive Officer

$\mathrm{CNI}$ - Confederação Nacional da Indústria

GRI- Global Reporting Initiative

ICMM- Conselho Internacional de Mineração e Metais

INSS - Instituto Nacional do Seguro Social

IUCN - International Union for the Conservation of Nature and Natural

Resources

ONGS - Organizações não Governamentais

QGCPO-Queensland Government Chief Procurement Office, Sustainable

procurement

SCM - Supply Chain Management

SSCM- Sustainable Supply Chain Management

WCED- World Commission on Environment and Development 


\section{Introdução}

Atualmente, sustentabilidade é um tópico importante para a maioria das organizações (Dahlmann et al. 2008; Tuttle e Heap, 2008). As atividades empresariais não se restringem apenas ao âmbito econômico, possuem também significativo efeito no meio ambiente e na sociedade. As atividades empresariais, quando feitas sem preocupação ambiental, podem contribuir para aumentar a poluição do ar, das águas e do solo, ocasionar mudanças climáticas, dentre outros impactos ambientais. Da mesma forma, a atuação de uma empresa afeta e é afetada por múltiplos grupos de interesses constituídos pelos seus acionistas, funcionários, fornecedores, consumidores e também a comunidade da região em que se localiza, constituindo uma rede de stakeholders (Azevedo, 2006).

Durante boa parte do século XX, as organizações empresariais, sob a ótica do desenvolvimento capitalista, atuavam apenas com uma perspectiva econômica, buscando a maximização de seus lucros e a consequente minimização de seus custos. As empresas eram vistas como progenitoras de progresso e bem-estar social nas comunidades onde atuavam, mesmo tendo como objetivo máximo o desenvolvimento a curto prazo de seus mercados e ignorando seus impactos diretos e indiretos no meio ambiente e na sociedade, com a justificativa de que este era um preço justo a pagar pelo incremento da qualidade de vida, do consumo e do crescimento econômico (Mota, 2006).

Este raciocínio, essencialmente reducionista e mecanicista, predominou até o início dos anos 1970, quando começaram a surgir movimentos de questionamento desta linha de pensamento, motivados pela constatação de que o planeta sofria impactos ambientais indesejados e preocupantes que poderiam, ao longo do tempo, esgotar os recursos disponíveis e prejudicar a sociedade como um todo. Um dos movimentos mais conhecidos neste sentido foi o chamado Clube de Roma (Mota, 2006). Os movimentos surgidos a partir daí, propuseram uma mudança no conceito de desenvolvimento, pelo entendimento da necessidade que este fosse sustentável, gerando equilíbrio entre a dimensão econômica e as questões ambientais e sociais (Mota, 2006). Barbosa (2007) apresenta em seu trabalho, o atual conceito de desenvolvimento sustentável, onde os componentes fundamentais para este tipo de desenvolvimento consistem em: crescimento econômico, proteção ao meio ambiente e igualdade social. Esses fundamentos, 
aliados à mudança do paradigma das empresas, que tinham como único foco o lucro, passaram por uma concepção de desenvolvimento sustentável, dando origem ao Triple Bottom Line da Sustentabilidade, conforme Figura 1.

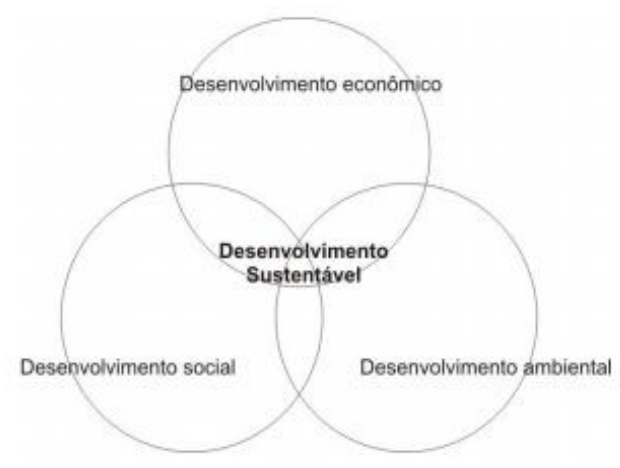

Figura 1- Interação Entre os Desenvolvimentos Econômico, Social e Ambiental. Fonte: Barbosa (2007)

O desenvolvimento sustentável está fundamentado no desejo de satisfazer as necessidades humanas presentes, sem comprometer a possibilidade das próximas gerações também satisfazerem as suas necessidades (CMMAD, 1991). Assim, as organizações antes vistas apenas como catalisadoras do processo econômico, hoje têm assumido outros papéis, inter-relacionando-se com vários agentes, para que possam continuar atuando em seus mercados. Segundo Melo e Froes (2001), as empresas deixam de ser apenas entidades econômicas, somente com preocupações financeiras e legais, e passam a considerar que sua atuação tem desdobramentos que não podem ser ignorados. Dessa forma, as empresas têm sido levadas, cada vez mais, a trabalharem o conceito de sustentabilidade. Neste sentido, por meio de uma boa estrutura de governança, as companhias atuam proativamente e de forma equilibrada nas dimensões social, ambiental e econômica, com o objetivo de aprimorar sua estratégia de negócios e garantir sua continuidade.

De acordo com Savitz e Weber (2006), sustentabilidade pode ser vista como a arte de fazer negócios em um mundo interdependente. Contudo, ao avaliar a sustentabilidade nas organizações empresariais, nota-se que o tipo de atividade na qual ela está inserida interfere em seus impactos socioambientais e influencia seu posicionamento em relação ao tema. Nesta linha, estudos como os de Masullo (2004) e Araya (2005), têm demonstrado que fatores como o grau de internacionalização das empresas e seu potencial poluidor, que podem estar 
ligados a alguns setores de negócios, são diferenciais na atuação da sustentabilidade.

Para a implementação do conceito de desenvolvimento sustentável em uma organização, é necessário o envolvimento e o esforço de diversos departamentos da empresa (Handfield et al., 1997; Wu e Dunn, 1995). Tate et al. (2010) afirmam que a área de Compras pode contribuir para a aplicação do conceito de sustentabilidade no ambiente empresarial. Isto ocorre principalmente devido ao posicionamento do processo de compras dentro da Cadeia de Suprimentos, como sendo o início do fluxo de materiais e serviços para a empresa (Carter et al., 1998; Porter e Van der Linde, 1995). Mais especificamente, cada organização é tão sustentável quanto sua cadeia de suprimentos a montante (Handfield et al.,2005; Krause et al., 2009). Portanto, companhias que possuem o objetivo de serem sustentáveis, devem primeiramente envolver seus fornecedores e estabelecer padrões ambientais e sociais de desempenho destes (Sharma e Henriques, 2005; Simpson et al., 2007). Consequentemente, a aplicação do conceito de sustentabilidade dentro de uma empresa, envolve necessariamente a implementação do conceito de sustentabilidade no processo de compras.

Além disso, o departamento de compras vem ganhando importância estratégica nos últimos anos, devido às empresas focarem em suas competências centrais e terceirizarem as atividades que não fazem parte destas competências (Harland et al., 1999). Seguindo esta linha, Leiria (1992) relata que o fundamental para uma empresa é ser excelente na sua essência, e, com a terceirização, esta pode transferir suas atividades não essenciais. Ainda de acordo com o autor, a expectativa em relação a esta ação, é de se conquistar um parceiro especialista na atividade que está sendo terceirizada. Saber comprar de forma a beneficiar a organização é determinante não somente para a competividade, mas também para a permanência da empresa no mercado. Pequenas reduções no custo das aquisições podem refletir positivamente no lucro da empresa. Para isso é fundamental manter um banco de dados de fornecedores atualizado, ter poder de negociação e estabelecer um relacionamento baseado na confiança mútua entre o cliente e o fornecedor. Compras é responsável pelo principal volume de gastos, considerando que, conforme destaca Arnold (1999), em média 50\% do custo de produção é representado pela aquisição de matérias-primas e serviços, conferindo à função Compras um enorme potencial de aumentar os lucros. Reforçando esta 
ideia, Ballou (2001) afirma que existe grande importância estratégica no setor de compras para as empresas, pois os valores gastos com itens comprados representam de 40 a $60 \%$ do valor final das vendas de qualquer produto, indicando que as reduções de custos conquistadas no processo de suprimentos resultam em um impacto direto sobre os lucros da organização.

\subsection{Objetivos}

Devido à importância que os temas Sustentabilidade e Compras representam para a sobrevivência das empresas no atual cenário mundial, este estudo tem como finalidade principal a aplicação e a avaliação de um modelo de portfólio de compras voltado para sustentabilidade para análise de uma área de compras de uma empresa mineradora, com a finalidade de criar estratégias para se obter um processo de Compras Sustentáveis. Assim, para atingir esta finalidade, este trabalho se propõe a responder a questão central abaixo:

- Como os elementos de sustentabilidade devem ser aplicados para a obtenção de uma Compra Sustentável?

Para ajudar a chegar nesta resposta, as perguntas abaixo foram formuladas:

- Qual a relação que existe entre sustentabilidade e contratações?

- Quais elementos devem ser estudados para a aplicação da sustentabilidade na contratação de serviços?

- Os itens que caracterizam uma contratação sustentável devem ser aplicados da mesma maneira para todos os tipos de compras?

O seguinte objetivo específico é proposto para o trabalho para auxílio do entendimento da questão central: aplicação do modelo de portfólio com sustentabilidade de Pagell et al. (2010), baseado no modelo de Kraljic (1983), em uma área de compras de uma empresa real pertencente ao setor de mineração para avaliação de sua aplicabilidade e visualização de seu resultado sob a ótica empírica.

Conforme exposto acima, a principal contribuição desta dissertação, através da busca por respostas para os questionamentos expostos e da aplicação do modelo proposto por Pagell et al. (2010) em uma empresa real, é a obtenção de um conjunto de diretrizes para a estruturação de estratégias voltadas a aplicação do conceito de compras sustentáveis numa área específica de compras. No 
entanto, o conjunto de decisões na estruturação da aplicação do modelo de Pagell et al. (2010) contém aspectos subjetivos a serem considerados, cujas medições são complexas, exatamente por serem de caráter pessoal e de difícil externalização. Assim como na matriz de Kraljic onde os julgamentos sobre as influências dos fatores de risco de suprimento e impacto nos lucros são dependentes da percepção da organização (ou de seus profissionais - entrevistados, em última análise), o mesmo pode ser dito do estudo realizado utilizando o modelo de Pagell et al.(2010).

\subsection{Delimitação}

O estudo foi realizado somente em uma empresa pertencente ao setor de mineração brasileiro, com sede na cidade do Rio de Janeiro. Embora esta empresa tenha atuação mundial, a área de Compras Estudada possui atuação somente nacional. Este trabalho foi realizado no período entre Janeiro/2014 a Setembro/2014.

Como delimitação deste estudo, pode-se dizer que o mesmo está compreendido na discussão sobre sustentabilidade aplicada no processo de compras de serviços $\mathrm{B} 2 \mathrm{~B}$ (business to business). As compras de materiais não serão objeto deste estudo. Além disso, o estudo de caso será focado apenas no quadrante alavancagem da matriz de portfólio de Kraljic. Neste quadrante estão as contratações que possuem uma importância de compra muito alta, mas baixa complexidade do mercado fornecedor. Maiores detalhes serão expostos na seção 2.1.4.

Este estudo será realizado na área de compras da Categoria de Movimentação Interna. Vale ainda ressaltar que a movimentação interna é a categoria de compras de serviços responsável pelas atividades de movimentação e transporte de produtos, insumos, rejeitos, entre outros, como também atividades de recuperação e manutenção de vias e umectação de pilhas e vias de acesso, dentro das instalações de mina, porto, usina ou ferrovia. 


\subsection{Estrutura da dissertação}

Para um melhor acompanhamento do estudo, o presente trabalho se divide em cinco capítulos, sendo este primeiro capítulo introdutório.

No segundo capítulo, apresenta-se a revisão da literatura relacionada ao tema central, com o objetivo de identificar os fatores de sustentabilidade que podem ser utilizados no processo de compras para que este seja caracterizado como sustentável. Além disso, neste capítulo é apresentado o modelo que será utilizado para a realização do estudo de caso.

O terceiro capítulo descreve o panorama do setor de mineração no Brasil, como este setor se relaciona com os temas sustentabilidade e compras e apresenta a empresa e a categoria estudadas.

O quarto capítulo apresenta a Metodologia Utilizada neste trabalho. Ainda neste capítulo é ilustrada a aplicação do modelo apresentado no capítulo 2, em uma empresa real, através de estudo de caso, visando o seu diagnóstico sob a ótica do modelo proposto na literatura (Estudo de Caso).

O quinto capítulo apresenta a discussão dos resultados obtidos, buscando identificar elementos comuns e particularidades entre a teoria e a prática. Os itens presentes no modelo e utilizados no estudo serão comparados com os resultados do Capítulo quatro. Finalmente, ainda no capítulo cinco serão apresentadas a conclusão desta dissertação e recomendações para trabalhos futuros. Referências bibliográficas e anexos completam este trabalho. 


\section{Fundamentação Teórica}

Neste capítulo, será abordado o referencial teórico utilizado como base de elaboração do trabalho. Primeiramente trata da definição de compras, sua importância e uma visão estratégica deste processo dentro das empresas. Em um segundo momento, este capítulo irá abordar o conceito de sustentabilidade mostrando sua evolução, definindo o conceito e os pilares que o sustentam no mundo corporativo e dentro do processo de compras.

A fundamentação teórica foi baseada em bases de dados como Science Direct, Google Acadêmico, Scielo, etc. por palavras chave como, por exemplo: Compra Estratégica, Sustentabilidade Empresarial, Modelos de Portfolio, Kraljic, Compras Sustentáveis, Terceirização, Cadeia de Suprimentos, Tripple Bottom Line, etc.

\subsection{Compras}

Uma cadeia de suprimentos é composta de empresas responsáveis pela transformação das matérias primas em produtos acabados até o seu destino final, ou seja, até que o consumidor final tome posse destas mercadorias e as consuma. As atividades de compras acontecem várias vezes ao longo deste processo, contribuindo para uma melhor composição de custos e redução de desperdícios ao longo da cadeia. Devido a isso, Compras não é mais vista como uma atividade rotineira e sim como parte do processo de logística das organizações, pois o setor de compras atualmente se interrelaciona com todos os outros setores da empresa, influenciando e sendo influenciado nas tomadas de decisões. Deste modo, a “função Compras" vem conquistando espaço e despertando maiores interesses das organizações, já que não basta apenas comprar, é preciso comprar bem, procurando obter o maior número de vantagens possível focando também no custo benefício (Martins e Alt, 2001).

O Departamento de Compras possui como responsabilidades principais a localização de fontes adequadas de suprimentos e a negociação de preços. O insumo vindo de outros departamentos, dentro de uma mesma empresa, é necessário para a busca e a avaliação das fontes de suprimento, auxiliando também o Departamento de Compras na negociação de preços e condições de 
fornecimento. Comprar, nesse sentido amplo, é responsabilidade de todos. Escolher o material/serviço certo exige insumos dos Departamentos de Marketing, Engenharia, Produção e Compras. Idealmente, as quantidades, especificações e a entrega dos suprimentos comprados são estabelecidas em conjunto pelos diversos departamentos, de acordo com o planejamento estratégico da mesma (Arnold, 1999).

Para Ballou (2004), a primeira esfera que se deve observar quando se estuda a área de Compras é o seu leque de papéis e responsabilidades. Para o autor, a função de Compras não apenas é positiva como essencial para uma organização e envolve a compra de matérias primas, suprimentos, serviços e componentes para a organização. Ainda de acordo com este autor, algumas das atividades associadas à área são a seleção e a qualificação de fornecedores; avaliação do desempenho dos prestadores de serviço e fornecedores de materiais; a negociação entre as partes interessadas em uma contratação; o monitoramento dos níveis de estoque para planejamento de futuras aquisições; entre outras. Para Pozo (2001), Compras deve ter a capacidade de comprar materiais e produtos na qualidade certa, na quantidade exata, no tempo certo, no preço correto e da fonte adequada.

Resumidamente, a área de Compras é responsável por gerenciar múltiplas interfaces internas e externas e conectar diversos elementos da cadeia de suprimentos, relacionando oferta, demanda e consumo de forma estratégica e lidando com alto nível de complexidade em seus processos.

\subsubsection{Evolução do Conceito de Compras}

Segundo Monczka et al. (2009), houve mais mudanças afetando Compras nos últimos 15 anos do que nos anteriores. Os autores identificaram obras relativas ao tema desde 1887, sendo que o primeiro livro com uma abordagem mais generalista data de 1905 .

Na Segunda Guerra Mundial, devido à escassez de materiais, o departamento de Compras ganhou maior importância, ao ser reconhecido como um agente capaz de encontrar fontes de suprimentos para as empresas (Fearon, 1968). Mas após este período, e até os anos 1970, a função Compras era reconhecida como algo necessário, mas com pouco a agregar às empresas (Hill, 
1975). O foco do departamento, neste período, era a negociação pelo menor preço e pela maior quantidade, num relacionamento puramente transacional com seus fornecedores (Frankel et al., 2008). Narasimham e Carter (1998) indicam que, apenas nos anos 1970 iniciou-se o questionamento do papel e contribuição de Compras ao desempenho da empresa.

Nos anos 1980, constatou-se que ineficiências na produção e na gestão do abastecimento não poderiam mais ser repassadas aos clientes na forma de aumento de preços (Cousins e Spekman, 2003). Na média, 60\% das receitas das empresas estavam sendo gastas com Compras junto a fornecedores (Laios e Moschuris, 2001). Neste cenário, as questões sobre quanto e quando comprar começaram a assumir o papel de condição de sobrevivência das empresas, e assim, o Departamento de Compras começou a ganhar mais visibilidade.

De acordo com Baily et al. (2000), no início dos anos 1990, a atividade de Compras ainda era muito burocrática, transacional e não havia muita comunicação com outras áreas da empresa. Contudo, ainda de acordo com o autor, a partir desta década, a globalização, a reengenharia de atividades, o aumento da competição e a pressão para redução de custos, fizeram com que a atenção das empresas fosse desviada para a área de Compras. No final dos anos 1990, a definição do conceito de Compras foi ampliada. Cooper et al. (1997) a definiram como um dos processos que compõem a Gestão da Cadeia de Suprimentos (SCM - Supply Chain Management). Essa nova abordagem defende que, com a aplicação dos princípios de SCM, as empresas podem melhorar a sua competitividade e a gestão do processo de Compras é parte importante nesta busca pela vantagem competitiva (Ireland et al., 2005). De acordo com Driedonks et al. (2010), com esta evolução, as empresas começaram a encarar o potencial de Compras como parte de sua estratégia na busca pela vantagem competitiva. As estruturas organizacionais de Compras passaram a ser flexíveis de forma a possibilitar o trabalho multidisciplinar e matricial com outras áreas da empresa de forma a seguir seu plano estratégico como um todo.

Em um ambiente cada vez mais dinâmico, a importância estratégica das atividades de Compras vem se evidenciando nas organizações, independentemente do tamanho e da natureza do negócio (Carter e Narasimhan, 1996; Weele, 2010). Cada vez mais, as empresas estão à procura de fornecedores externos para prover serviços ao negócio, que anteriormente eram executados internamente (Agndal et 
al., 2007; Nordin, 2008). Axelsson e Wynstra (2002) citam como razões para essa tendência o rápido desenvolvimento tecnológico, a complexidade dos produtos e mercados e um número crescente de empresas especializadas e flexíveis no mercado.

Uma visão simplista muito comum, em relação à atividade de Compras, é considerá-la como o mero ato de comprar. Para Neiva e Gomes (2011), esta percepção está baseada na ideia de que o ato de comprar diz respeito a simples troca. $\mathrm{O}$ interesse básico do comprador nesse cenário fica restrito a adquirir o volume máximo de recursos pela menor quantia de dinheiro que for necessário pagar (Baily et al., 2000).

Porém, pode-se perceber que, com a evolução das organizações, a área de Compras vem ganhando cada vez mais uma importância estratégica. Dentro desta, o conceito de Compras é entendido como um processo de identificação, avaliação, negociação e contratação das fontes de fornecimento para produtos necessários para o funcionamento da organização, visando maximizar os resultados dentro de um cenário competitivo (Neves e Hamacher, 2004).

\subsubsection{Compra Estratégica}

Conforme mostrado nos tópicos anteriores, a área de Compras desempenha um papel fundamental na realização dos objetivos estratégicos da empresa, pois pode afetar a rápida entrega de produtos e serviços, entregas no tempo certo, além dos custos da operação e qualidade do produto/serviço, elementos chaves na estratégia de operações de qualquer empresa (Gaither e Frazier, 2001). Devido a isto, neste tópico será abordada uma visão estratégica do conceito de Compras.

Conforme sintetizado por Martins (2005), baseado nos estudos de Monczka et al. (2002), Compra Estratégica pode ser definida como um conjunto de funções e atividades realizadas pela Área de Compras, de forma a atingir os objetivos traçados pelo planejamento estratégico da organização. Assim, segundo Baily e Farmer (2000), as decisões estratégicas do processo de compras devem ser definidas em sintonia com o conteúdo e a direção das decisões estratégicas empresariais. Este foco estratégico implica que os envolvidos com a área de Compras devem concentrar grande parte de seus esforços em atividades de negociação de relacionamentos a prazos mais longos, desenvolvimento de 
alianças e parcerias estratégicas com fornecedores e redução de custo total de pacotes de compra, ao invés de efetuar cada pedido de forma isolada e sem visão estratégica. Para Carr e Smeltzer (1999), a função de Compras Estratégicas é direcionar suas atividades para objetivos e metas de longo prazo, que visam dar vantagem competitiva à organização.

Neves e Hamacher (2004) definem o conceito de Compra Estratégica como um processo que envolve a identificação sistemática das potenciais fontes de fornecimento de itens necessários ao funcionamento das empresas (produtos ou serviços), da avaliação, negociação e contratação de fornecedores com um contínuo gerenciamento dessa relação, sempre com o objetivo de aumentar a competitividade das empresas. Ainda de acordo com os autores, a utilização do modelo de Compra Estratégica tem feito com que as empresas se aprofundem nos estudos de suas categorias ou famílias de produtos, no seu mercado fornecedor, nos seus volumes de compras e estabeleça formas diferenciadas de relacionamento com o mercado. Na busca de novas formas de relacionamento com o mercado, procura-se agregar volumes aos fornecedores, ajustar as especificações dos itens comprados para padronização, verificar a procedência da demanda dos produtos e, principalmente, reestruturar a forma de negociação e contratação dos processos e da estrutura de suprimentos das empresas. Baseandose na integração das informações, este modelo possibilita a ampliação do relacionamento com fornecedores de um estágio comum para um relacionamento estratégico, e de longo prazo, o que pode gerar vantagem competitiva para a empresa.

Resumidamente, o processo de Compra Estratégica está sempre buscando oportunidades de agregar valor à cadeia de fornecimento, analisando os itens a comprar, gerenciando compras realizadas, o relacionamento com os fornecedores, a avaliação e a aplicação de planos estratégicos alinhados com o planejamento das empresas, de modo a gerar vantagem competitiva. O papel estratégico do processo de compras é muito afetado pelo estágio de amadurecimento gerencial atingido pela organização. Quanto mais desenvolvida a organização, mais provável é que ela seja uma atividade estratégica interfuncional, objetivando a agregação de valor e permitindo maior vantagem competitiva à organização (Santos, 2002). Para Alaniz e Shuffield (2001), o modelo de compra estratégica é baseado em fatores como a capacidade dos fornecedores no desenvolvimento de integração com seus 
clientes e assim desenvolverem atividades que façam a diferença no produto final, ou seja, o processo de compras estratégico é voltado para análise e tomada de decisão baseada no impacto estratégico que o produto (ou o fornecedor) terá no negócio da empresa compradora. Na Tabela 1 são destacadas diferenças entre compras transacionais e compras estratégicas.

Tabela 1- Diferenças entre Processos de Compras Estratégica e Transacional Fonte: Alaniz e Shuffield, 2001

\begin{tabular}{|c|l|l|}
\cline { 2 - 4 } \multicolumn{1}{c|}{ Objetivo } & $\begin{array}{l}\text { Contratos de longo prazo; Gestão do } \\
\text { relacionamento com as empresas fornecedoras. }\end{array}$ & $\begin{array}{l}\text { Transação de processos de acordo } \\
\text { com contratos pré-estabelecidos }\end{array}$ \\
\hline $\begin{array}{l}\text { Atividade } \\
\text { Principal }\end{array}$ & $\begin{array}{l}\text { Seleção de fornecedores e negociação de } \\
\text { contratos de fornecimento }\end{array}$ & $\begin{array}{l}\text { Pouca interação entre comprador e } \\
\text { fornecedor }\end{array}$ \\
\hline Impacto & $\begin{array}{l}\text { Redução no custo dos insumos/serviços } \\
\text { adquiridos e consequentemente nos } \\
\text { produtos/serviços vendidos }\end{array}$ & $\begin{array}{l}\text { Redução no custo do processo e no } \\
\text { registro de dados }\end{array}$ \\
\hline $\begin{array}{l}\text { Habilidade } \\
\text { Necessária }\end{array}$ & $\begin{array}{l}\text { Análise de dados e composiçães de custos, } \\
\text { negociação de contratos, capacidade de } \\
\text { construção e manutenção de relacionamento } \\
\text { com fornecedores }\end{array}$ & Atividades operacionais \\
\hline Natureza & $\begin{array}{l}\text { Tarefas não rotineiras } \\
\text { Tarefas rotineiras e operacionais }\end{array}$ \\
\hline
\end{tabular}

\subsubsection{Processo de Compra Estratégica}

Executar o processo de Compras é como realizar um conjunto de ações e fatores dinâmicos que começam com a identificação de um estímulo para uma ação e terminam com o respectivo atendimento a esta ação (Laios e Moschuris, 2001). Este processo não deve focar somente no resultado final, mas sim nos vários eventos e relacionamentos entre as diversas áreas que fazem parte do processo (Gronhaug e Venkatesh, 1991).

Na visão de Monczka et al. (2002), o foco no processo de compras traz muitos benefícios para as empresas, entre os quais:

- Redução de custos;

- Melhor processo de entrega;

- Ciclos de pedidos menores, incluindo o ciclo de desenvolvimento de produtos;

- Acesso a novas tecnologias de processos e produtos;

- Melhoria da qualidade.

De acordo com Laios e Moschuris (2001), de forma mais básica, o processo de Compras pode ser decomposto em quatro fases: 
a) Início: a partir de uma requisição de um cliente interno, devem ser validadas especificações, preços e prazos estimados;

b) Procura: o departamento irá buscar potenciais fornecedores que possam atender à requisição;

c) Seleção: estabelecimento de métodos de precificação, critérios para a seleção de fornecedores, e colocação do pedido de compra;

d) Finalização: emissão do pedido, administração do contrato e recebimento.

Considerando uma visão estratégica, Dobler e Burt (1996) afirmam que o processo de compra estratégica envolve várias atividades, que vão desde a participação na elaboração, ou desenho, do produto/serviço a ser adquirido, até a participação no planejamento estratégico da organização. Wisner e Stanley (2007) determinam o processo de compras estratégicas em seis fases, conforme apresentado na Figura 2. Embora existam diversos modelos de Processo de Compras Estratégicas na literatura, este foi escolhido por se aproximar da realidade da empresa estudada. As três primeiras envolvem a preparação para a aquisição e são realizadas juntamente à avaliação da situação atual. As três fases seguintes envolvem efetivamente o processo de compra de bens e serviços.

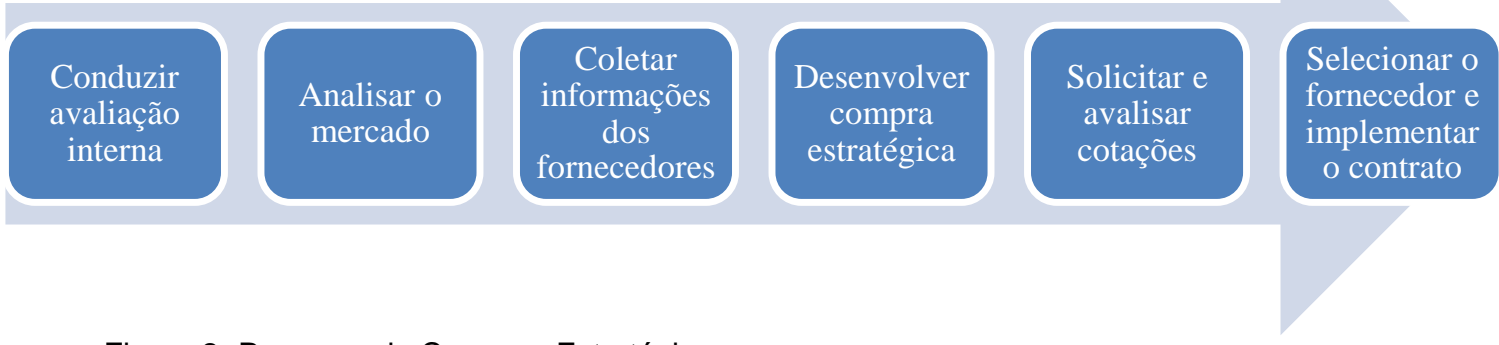

Figura 2- Processo de Compras Estratégicas

Fonte: Wisner e Stanley (2007)

Inicialmente é realizada uma avaliação interna, estruturando um banco de dados com diversas informações importantes para a compra junto a outros departamentos da empresa. Em seguida, a empresa deve proceder a uma avaliação de mercado, fundamentada nas cinco forças competitivas do Modelo de Porter (1986) e na matriz do Modelo de Portfolio de Compras de Kraljic (1983). Na terceira fase, coletam-se informações dos fornecedores, essenciais para desenhar as modalidades de compra, tais como: registro de fornecedores usados no passado; catálogo eletrônico; publicações e websites. A função Compras usará esta informação para restringir a lista de fornecedores disponíveis àqueles que estão 
mais próximos aos critérios pré-escolhidos pela organização. A quarta fase busca desenvolver a compra estratégica com base nos resultados da Matriz de Kraljic. Já na quinta fase, deve solicitar e avaliar as cotações dos fornecedores, para que na última fase, sexta, selecione-se o fornecedor, assine-se o contrato de suprimento e seja realizado constantemente o acompanhamento deste.

Um dos pontos mais importantes do processo de compras é selecionar a fonte de suprimento mais adequada à empresa. Esta é a mais importante dentre todas as responsabilidades identificadas com o Departamento de Compras (Martins, 2005).

Segundo Bertaglia (2006), o processo de seleção de fornecedores não é simples. A complexidade aumenta em função das características do item ou serviço a ser comprado, pois as exigências podem ser maiores ou menores. $\mathrm{O}$ ato de comprar deixou de ser simplesmente o de efetuar uma cotação de preços. Há três características básicas que devem ser consideradas em um processo de decisão para se selecionar um fornecedor: preço, qualidade e serviço. Para a seleção de fornecedores existem critérios que têm deixado de ser somente aqueles básicos, ou seja, o preço ao qual o fornecedor oferecia o produto, a qualidade do produto, que deveria atender à especificação mínima requerida pela empresa, e a velocidade de entrega do produto pelo fornecedor. O custo total de aquisição, que considera todos os custos associados à aquisição do produto; a qualidade total oferecida pelo fornecedor (não somente a qualidade mínima necessária); o serviço prestado pelo fornecedor, que além da velocidade de entrega passou a considerar a confiabilidade, o custo de transporte, a consistência, a frequência de entregas e a flexibilidade do fornecedor; a capacidade tecnológica e de processo do fornecedor; sua saúde financeira; e a estrutura e estratégia organizacional do fornecedor, estão entre os novos critérios que passaram a ser adotados. Neste mesmo raciocínio, de acordo com Dias (1995), atividades como a identificação de potenciais fornecedores, análise de mercado, gestão de contratos, negociação, especificação de bens e serviços, seleção e avaliação de fornecedores, representariam os elementos principais do processo de compras. 


\subsubsection{Modelo de Kraljic para Gestão Estratégica}

Conforme exposto por Martins (2005) sabe-se que a função Compras é, ou deveria ser, uma área estratégica para as empresas que buscam maior competitividade nos mercados onde atuam. Ainda de acordo com o autor, é extremamente importante que as áreas responsáveis pelos suprimentos de materiais e serviços das empresas desenvolvam processos estratégicos de aquisição para a obtenção desses itens que estejam de acordo com as metas e prioridades da organização.

Martins (2005) ainda diz que há diversas metodologias para estabelecer as estratégias de compras a serem adotadas para a aquisição dos produtos e serviços. Em geral se faz uma classificação dos itens, em grupos, de forma que estratégia semelhante seja adotada para todos os produtos que apresentem as mesmas características desta classificação. Em artigo, Kraljic (1983) faz amplo uso do conceito de Categoria, empregado para agrupar sob um mesmo contexto serviços com características similares. A partir deste conceito, analisa-se a importância relativa de cada categoria para a empresa, visando à racionalização de ativos e uso dos recursos na gestão de bens e serviços mais relevantes para a companhia. Entre os fatores que estimulam a constituição de uma categoria, cita-se: (i) a existência de características similares; (ii) a presença de fornecedores similares / mercados coincidentes; (iii) a identificação de sinergia natural. Dentre as formas de classificação utilizadas há a classificação pelo custo do produto para a empresa (classificação $\mathrm{ABC}$ ), a análise de portfólio etc. Este estudo irá focar na abordagem do modelo de Kraljic (1983), por ter sido o primeiro modelo de portfolio de compras e por ainda ser uma referência neste tema nos dias atuais, para estabelecimento da estratégia de compras a ser adotada e irá apenas descrever como é feita a classificação ABC para fins de comparação entre os modelos.

\section{- Classificação ABC}

O sociólogo e economista italiano Vilfredo Pareto é considerado o criador da classificação ABC e durante seu estudo sobre a distribuição de renda, concluiu que o grande percentual de riqueza do seu país estava concentrado em pequena parte da população, ou seja, $80 \%$ da riqueza local estavam centralizado sem $20 \%$ da população. A partir desse estudo, esta ferramenta tem sido aplicada a outras 
áreas e ramos de atividades, como por exemplo, industrial e comercial (Pereira, 2005).

Existem diversas abordagens sobre a aplicação da classificação ABC, com diversos percentuais. Uma das formas mais usuais, é a de que através da soma cumulativa (em ordem de gasto), selecionam-se os produtos que, somados, representem $80 \%$ do custo total da empresa, o que corresponde a aproximadamente $20 \%$ dos itens comprados pela empresa. Estes são classificados como itens A, sendo caracterizados como os principais da empresa. Continuando a soma cumulativa, agrupam-se os itens seguintes até que a soma do valor corresponda a $98 \%$ do custo total da empresa. Estes $18 \%$ (98\% menos $80 \%$ dos itens A) representam aproximadamente $30 \%$ dos itens comprados, e são classificados como itens B. Os $2 \%$ restantes (em valor), correspondem geralmente aos 50\% restantes dos itens, que são classificados como C. Os itens de classificação A merecem uma atenção especial, pois na classificação ABC, estes seriam os itens de maior importância para a empresa (pelo menos em termos financeiros). Esta classificação dos produtos embasaria o desenvolvimento das estratégias de compras, concentrando esforços (estudo de mercado, avaliação de riscos de fornecimento etc.) e dedicando menos tempo gerencial com itens de menor importância (contratos de curta duração, compras spot etc.) (Leenders e Fearon, 1993; Steele e Court, 1996).

No entanto, este método é voltado principalmente à gestão de estoques e não considera questões como a importância do item em relação à operação do sistema como um todo. Em outras palavras, a criticidade do item não é levada em consideração (Steele e Court, 1996). Neste sentido, Gelderman e Van Weele(2005) afirmam que a Análise ABC concentra-se no valor financeiro do item, ignorando o custo da falta de qualidade, risco de desempenho, risco social e outros, além de não propor estratégias para cada tipo de item.

\section{- Modelo de Portfólio de Compras de Kraljic}

Os métodos de portfólio de compras são sistemáticas que permitem a avaliação da importância estratégica de uma determinada compra sob vários aspectos, bem como das dificuldades em gerenciar a compra. O método de portfólio de compras consiste na necessidade de gestores desenvolverem 
estratégias distintas para cada tipo de mercado fornecedor e categoria de itens comprados, de modo a permitir ganhos à empresa na gestão de suprimentos (Weele, 2002). Esta necessidade de desenvolver estratégias distintas decorre da impossibilidade de empregar relacionamentos avançados a todos os fornecedores, devido à restrição de recursos e a fatores externos.

Kraljic (1983) introduziu o primeiro método de portfólio de compras. O Modelo de Kraljic é considerado como uma referência importante no desenvolvimento da teoria no campo da gerência de suprimento. Embora existam críticas a esse modelo, outras abordagens sobre modelos de gestão de compras pesquisado na literatura têm como referência ainda ao Modelo de Kraljic (Hadeler e Evans, 1994; Olsen e Ellram, 1997 e Bensaou, 1999). A partir de Kraljic, surgiram outros que incluíam variáveis e apresentavam modificações justificadas pela necessidade de contemplar questões importantes para a atual gestão de suprimentos.

Conforme a Figura 3, o modelo proposto por Kraljic (1983) classifica os produtos comprados de acordo com seu impacto sobre a lucratividade da empresa (importância) e o risco de fornecimento (complexidade do mercado fornecedor). Dividido em quatro passos, o método cria uma estrutura de categorização dos itens comprados e do mercado fornecedor. Diferentes estratégias de suprimentos são sugeridas por meio destas categorizações. 


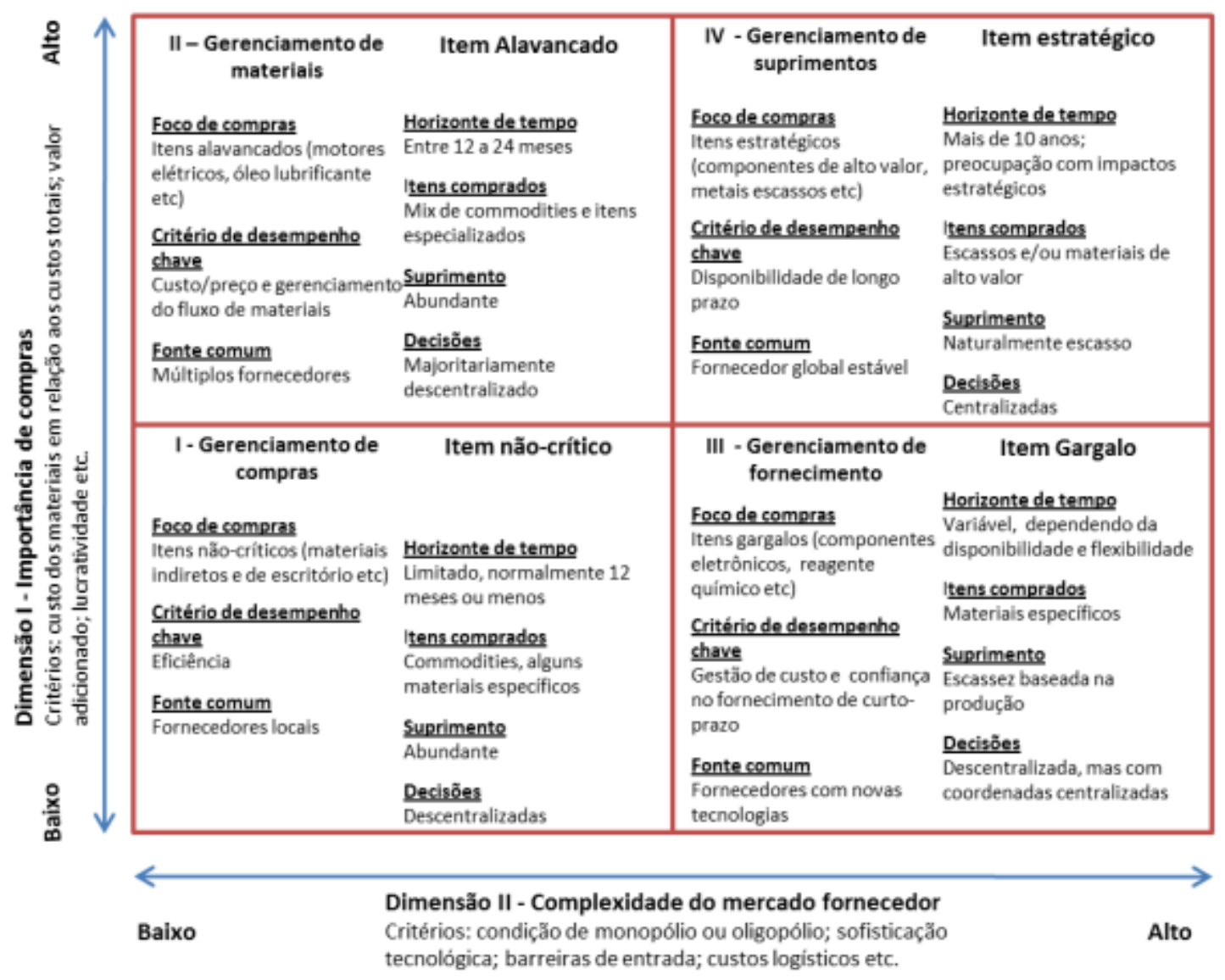

Figura 3- Modelo de Análise de Portfólio

Fonte: Adaptado de Kraljic,1983

Os quatro passos para aplicação do modelo de Kraljic serão descritos a seguir:

Passo 1: Classificar os itens comprados: O primeiro passo do método de Kraljic (1983) consiste em classificar os itens comprados. Para isto, o autor criou uma matriz 4 x 4 (Figura 3) com os seguintes eixos:

- Importância das Compras: localizada no eixo vertical, é derivada da participação percentual dos itens comprados no custo total e seus impactos na lucratividade. Indica o potencial da compra para aumentar a rentabilidade da empresa.

- Complexidade do Mercado Fornecedor: localizado no eixo horizontal, é composto das variáveis de escassez de suprimentos, avanço tecnológico, substituição de materiais e poder de compra. Ou seja, este eixo contém as vulnerabilidades da empresa compradora frente ao mercado fornecedor do produto comprado.

Além disto, para classificar as compras no método de portfólio, a empresa precisa atribuir pesos aos critérios e fatores, baseados na percepção dos gestores e 
informações da organização (Olsen e Ellram, 1997; Gelderman e Van Weele, 2003). Kraljic (1983) não descreve qual deve ser o método de atribuição de pesos para os eixos. Outros autores, como Olsen e Ellram (1997), sugerem em seu modelo o método de Narasimhan (1983). Este método, exposto no Anexo II aplicado ao modelo de Olsen e Ellram (1997) exposto no Anexo I, é usado para que se consiga posicionar os produtos comprados dentro dos quadrantes e consiste em avaliar o item comprado. Por exemplo, se um item possui uma importância de compra muito alta, mas baixa complexidade do mercado fornecedor, ele seria inserido no quadrante de Itens de Alavancagem.

Com intuito de tornar mais claro o assunto, Baily et al. (2000) sugerem alguns exemplos que ajudam a explicar os significados das categorias e a idéia de posicionamento. $\mathrm{O}$ motor de avião para uma empresa da indústria aeronáutica pode ser atribuído como um elemento Estratégico, pois, a priori, é um item com alta importância de compra e complexidade do mercado fornecedor. Papel para uma gráfica pode ser avaliado como baixa complexidade de mercado fornecedor, mas alta importância da compra que o coloca na categoria de Alavancagem. No quadrante Gargalo, devem ser posicionados os produtos de baixa importância da compra, porém com alta complexidade do mercado fornecedor. Uma consultoria especializada é exemplo de item Gargalo. Por fim, pode-se classificar como itens Não Críticos, materiais de escritório, os quais são de baixa importância da compra e complexidade do mercado fornecedor.

Por meio da matriz apresentada na Figura 3, Kraljic (1983) construiu uma ferramenta de fácil visualização e que contempla as quatro categorias fundamentais para a tomada de decisão em compras e gestão de fornecedores. Dado o posicionamento dos itens de compras na Figura 3, é necessário analisar algumas das atividades principais, informações requeridas e níveis de decisão de cada uma das categorias que estão listadas na Tabela 2. 
Tabela 2- Atividades e Informações Demandadas por Cada Tipo de Item Fonte: Kraljic, 1983

\begin{tabular}{|c|c|c|c|}
\hline $\begin{array}{l}\text { Foco de } \\
\text { Compras }\end{array}$ & Atividades Principais & Informação Requerida & $\begin{array}{l}\text { Nível de } \\
\text { Decisão }\end{array}$ \\
\hline $\begin{array}{l}\text { Itens } \\
\text { Estratégicos }\end{array}$ & $\begin{array}{l}\text { - Previsão de demanda acurada } \\
\text { - Estudo detalhado do mercado fornecedor } \\
\text { - Desenvolvimento de relacionamento com } \\
\text { fornecedores de longo prazo } \\
\text { - Decisões de produzir ou comprar } \\
\text { - Análise de Risco } \\
\text { - Plano de Contingência } \\
\text { - Controle logístico (transporte e } \\
\text { armazenagem) }\end{array}$ & $\begin{array}{l}\text { - Dados detalhados do } \\
\text { mercado fornecedor } \\
\text { - Informações de } \\
\text { fornecimento e demanda } \\
\text { no curto e longo prazo } \\
\text { - Inteligência competitiva } \\
\text { - Curvas de custos } \\
\text { industriais }\end{array}$ & $\begin{array}{l}\text { Top (cúpula da } \\
\text { empresa) }\end{array}$ \\
\hline Itens Gargalo & $\begin{array}{l}\text { - Assegurar volume } \\
\text { - Controle dos fornecedores } \\
\text { - Estoques de segurança } \\
\text { - Planos de substituição }\end{array}$ & $\begin{array}{l}\text { - Previsões de } \\
\text { demanda/fornecimento em } \\
\text { médio prazo } \\
\text { - Dados detalhados do } \\
\text { mercado fornecedor }\end{array}$ & $\begin{array}{l}\text { Alto nível } \\
\text { (chefes dos } \\
\text { departamentos) }\end{array}$ \\
\hline $\begin{array}{l}\text { Itens } \\
\text { Alavancagem }\end{array}$ & $\begin{array}{l}\text { - Exploração do poder de compra } \\
\text { - Seleção de fornecedor } \\
\text { - Substituição do fornecedor } \\
\text { - Estratégias/negociações de preços alvos } \\
\text { - Otimização do volume de pedidos }\end{array}$ & $\begin{array}{l}\text { - Informações adequadas } \\
\text { do mercado fornecedor } \\
\text { - Planejamento da demanda } \\
\text { - Dados precisos do } \\
\text { fornecedor }\end{array}$ & $\begin{array}{l}\text { Nível médio } \\
\text { (comprador } \\
\text { chefe) }\end{array}$ \\
\hline $\begin{array}{l}\text { Itens Não- } \\
\text { Críticos }\end{array}$ & $\begin{array}{l}\text { - Padronização de produtos } \\
\text { - Otimização/monitoramento de volume dos } \\
\text { pedidos } \\
\text { - Processamento eficiente das compras }\end{array}$ & $\begin{array}{l}\text { - Boa visão geral do } \\
\text { mercado fornecedor } \\
\text { - Previsões de demanda de } \\
\text { curto prazo }\end{array}$ & $\begin{array}{l}\text { Nível baixo } \\
\text { (compradores) }\end{array}$ \\
\hline
\end{tabular}

Passo 2: Analisar o mercado fornecedor sob a ótica de poder do comprador versus do fornecedor: Com os itens de compra posicionados e as atividades indicadas compreendidas, o segundo passo é avaliar o poder de compra das partes envolvidas. Esta avaliação é mais um auxílio à tomada de decisão em compras e gestão de fornecedores. Pode-se evitar o estabelecimento de estratégias inválidas ou com baixa eficácia frente à natureza de um mercado fornecedor. A comparação feita na Tabela 3, com dados do fornecedor e da empresa compradora, permite à empresa avaliar o quanto ela está habilitada para usufruir do poder de compra. 
Tabela 3- Fatores para Avaliação da Força do Comprador e do Fornecedor Fonte: Kraljic, 1983

\begin{tabular}{|l|l|l|}
\hline$\#$ & \multicolumn{1}{|c|}{ Força do fornecedor } & \multicolumn{1}{c|}{ Força do Comprador } \\
\hline $\mathbf{1}$ & $\begin{array}{l}\text { Tamanho do mercado versus capacidade do } \\
\text { fornecedor }\end{array}$ & $\begin{array}{l}\text { Volume de compra versus capacidade das } \\
\text { unidades principais }\end{array}$ \\
\hline $\mathbf{2}$ & $\begin{array}{l}\text { Crescimento do mercado versus crescimento da } \\
\text { capacidade }\end{array}$ & $\begin{array}{l}\text { Crescimento da demanda versus } \\
\text { crescimento da capacidade }\end{array}$ \\
\hline $\mathbf{3}$ & $\begin{array}{l}\text { Utilização da capacidade produtiva ou risco de } \\
\text { gargalo }\end{array}$ & $\begin{array}{l}\text { Utilização da capacidade das unidades } \\
\text { principais }\end{array}$ \\
\hline $\mathbf{4}$ & Estrutura competitiva & $\begin{array}{l}\text { Participação de mercado em relação aos } \\
\text { concorrentes }\end{array}$ \\
\hline $\mathbf{5}$ & ROI e/ou ROC & $\begin{array}{l}\text { Lucratividade dos principais produtos } \\
\text { finais }\end{array}$ \\
\hline $\mathbf{6}$ & Estrutura de custo e preço & Estrutura de custo e preço \\
\hline $\mathbf{7}$ & Ponto de Equilíbrio & Custo de atraso na entrega \\
\hline $\mathbf{8}$ & Exclusividade de produto e estabilidade tecnológica & Capacitação de produção própria \\
\hline $\mathbf{9}$ & Barreiras de capital e requisitos de know how & $\begin{array}{l}\text { Custo para novas fontes versus custo para } \\
\text { produção própria }\end{array}$ \\
\hline
\end{tabular}

Kraljic (1983) considera que seis, dos pontos enunciados acima, merecem uma explicação mais cuidada:

- Utilização da capacidade do fornecedor (3): este critério indica o risco de estrangulamento do abastecimento. Por exemplo, quando os fornecedores estão a trabalhar a $90 \%$ da sua capacidade, um aumento da procura poderá levar a limitações de fornecimento;

- Ponto de equilíbrio para estabilidade (7): um fornecedor que atinge o equilíbrio, por exemplo, aos $70 \%$ da sua capacidade, conseguirá apresentar custos mais baixos que, um fornecedor, que apenas atinja o equilíbrio aos $80 \%$, logo terá mais capacidade negocial, porque consegue trabalhar mais tempo em subutilização da capacidade;

- Exclusividade do produto (8): acontece quando se verifica escassez natural, alta sofisticação tecnológica e barreiras à entrada no mercado. Quando um produto é único, o fornecedor tem mais capacidade para impor a sua posição;

- Volume de compras (1): é um dos principais argumentos negociais. O volume de compras é importante porque pode permitir ao fornecedor obter economias de escala com impacto no custo final do produto;

- Variações passadas da utilização da capacidade produtiva (3): a empresa consegue avaliar a flexibilidade do seu abastecimento, pelas variações da procura no passado. Assim, por exemplo, se a empresa realizar promoções aumentando a sua produção, mas a capacidade dos fornecedores estiver no limite, isto pode obrigar a empresa a pagar um 
prémio pelo aumento do abastecimento, que se traduzirá num aumento de custo de produção e uma redução de lucro;

- Custo de atraso entrega (7): quanto maiores forem estes custos, maior será o risco e menor será a capacidade da empresa para rapidamente mudar o fornecedor ou atrasar as negociações.

A empresa deve, sistematicamente, analisar o mercado para avaliar a disponibilidade (quantidade e qualidade) de materiais estratégicos e o nível da "força" relativa dos fornecedores. Posteriormente, deverá analisar as suas necessidades e linhas de abastecimento para verificar se pode ser abastecida nos termos em que deseja. É essencial que a empresa consiga identificar os pontos fortes e limitações do fornecedor, assim como, compreender o impacto que eles podem ter na organização e no balanceamento do poder entre comprador e fornecedor (Carvalho, 2010).

Passo 3: Posicionamento estratégico: Consiste em posicionar o item comprado através da avaliação feita no segundo passo (análise do poder de compra) na matriz ilustrada na Figura 4. Onde o comprador possuir força superior ao mercado fornecedor, é indicado que a empresa opte por uma estratégia agressiva de "explorar". Na situação de equilíbrio de forças, sugere-se a estratégia ponderada de "balancear". Em caso de predomínio do mercado fornecedor, tornase prudente a empresa adotar uma estratégia defensiva de "diversificar" ou seja, trabalhar com mais de 01 fornecedor. Estes três tipos de estratégias são bastante óbvios (Caniëls e Gelderman, 2005) já que se referem às regras básicas de uma estrutura de poder. Porém, segundo os mesmos autores, nenhuns dos métodos de portfólio ignora a questão de assimetria de poder, que é um dos fatores determinantes nos relacionamentos entre fornecedor e comprador. A diferença é que a estratégia simplesmente baseada em poder de compra revela-se perigosa diante das rápidas mudanças das condições de mercados. 


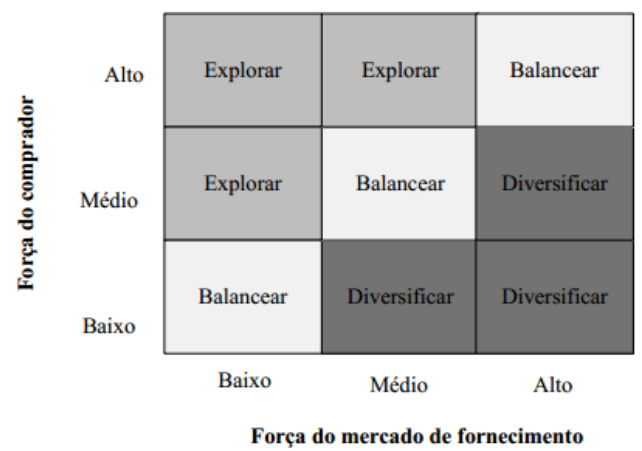

Figura 4- Posicionamento Estratégico do Poder de Compra Fonte: Kraljic, 1983

I. Explorar: É uma estratégia agressiva, aplicada a artigos sobre os quais o comprador tem um papel dominante no mercado. A "força" do fornecedor é média ou baixa, o risco de abastecimento, também, será médio/baixo, o que proporciona à empresa uma oportunidade para pressionar os seus fornecedores e conseguir melhores preços. No entanto, tem de considerar que uma pressão exagerada sobre os preços pode motivar reações contrárias dos fornecedores e prejudicar o fornecimento no longo-prazo.

II. Equilíbrio: Para materiais que não apresentam riscos de abastecimento nem grande benefício económico, a empresa deve adotar uma estratégia equilibrada. O comprador deve ter em conta que um comportamento excessivamente agressivo pode motivar uma degradação das relações com o fornecedor e um comportamento excessivamente defensivo pode ser considerado conservador, originando piores situações de compra do que as esperadas.

III. Diversificar: Esta estratégia implica a procura de produtos substitutos e/ou novos fornecedores. As organizações devem optar por esta estratégia quando os fornecedores têm uma posição forte no mercado e a empresa uma posição secundária.

Passo 4: Plano de ações: No passo anterior, foram estabelecidas posições estratégicas baseadas no equilíbrio de forças entre fornecedor e comprador. Cada uma destas posições requer ações e diretrizes específicas para diversos itens, conforme ilustrado na Tabela 4. Neste passo não é tratada nenhuma política/ação de parceria para o aprimoramento da relação fornecedor-comprador. 
Tabela 4- Implicações das Posições Estratégicas Escolhidas

Fonte: Kraljic, 1983

\begin{tabular}{|l|l|l|l|}
\hline $\begin{array}{l}\text { Itens da política de } \\
\text { suprimentos }\end{array}$ & $\begin{array}{l}\text { Posição estratégica - } \\
\text { "explorar" }\end{array}$ & $\begin{array}{l}\text { Posição estratégica - } \\
\text { "balancear" }\end{array}$ & $\begin{array}{l}\text { Posição estratégica - } \\
\text { "diversificar" }\end{array}$ \\
\hline Volume & $\begin{array}{l}\text { Distribuir entre os } \\
\text { fornecedores }\end{array}$ & $\begin{array}{l}\text { Manter ou alterar } \\
\text { cuidadosamente entre os } \\
\text { fornecedores }\end{array}$ & Centralizar \\
\hline Preço & Pressionar por reduções & $\begin{array}{l}\text { Negociar em cima de } \\
\text { oportunidades }\end{array}$ & Mantê-lo \\
\hline Cobertura contratual & Comprar sob demanda & $\begin{array}{l}\text { Balancear entre contratos } \\
\text { e compra sob demanda }\end{array}$ & $\begin{array}{l}\text { Garantir o fornecimento } \\
\text { através de contratos }\end{array}$ \\
\hline Novos fornecedores & Manter contato & Selecionar fornecedores & Procurar intensivamente \\
\hline Estoques & Manter baixo & $\begin{array}{l}\text { Usar estoques como } \\
\text { pulmão }(\text { buffer } \text { ) }\end{array}$ & Estoque intensivo \\
\hline Produção própria & Reduzir ou não produzir & Decidir seletivamente & Produzir \\
\hline Substituição & Manter contato & $\begin{array}{l}\text { Procurar boas } \\
\text { oportunidades }\end{array}$ & Procurar intensivamente \\
\hline Logística & Minimizar custos & Otimizar seletivamente & $\begin{array}{l}\text { Estoques de segurança } \\
\text { suficientes }\end{array}$ \\
\hline
\end{tabular}

Analisando a Tabela 4 podemos retirar as seguintes conclusões, em relação à atuação das organizações:

- Explorar: quando o comprador tem uma posição mais forte que o fornecedor deve: explorar preços, dispersar o volume de compra por múltiplos fornecedores e reduzir níveis de inventário;

- Diversificar: Quando o fornecedor tem uma posição dominante e a estratégia é a diversificação, a empresa deve:

o Consolidar o abastecimento, concentrando compras fragmentadas, num único fornecedor, aceitar preços mais elevados e estabelecer contratos para garantir a satisfação das necessidades de abastecimento; o Para reduzir o risco de abastecimento, face à elevada dependência num único fornecedor, a empresa deve ter disponíveis fontes alternativas de abastecimento. Para tal, deve procurar fornecedores alternativos, produtos substitutos e até considerar produção própria, caso se justifique.

- Equilibrar: Quando nenhuma das partes tem uma posição dominante é aconselhável adotar uma estratégia balanceada e equilibrada.

Uma das maiores críticas ao modelo proposto por Kraljic é que, ao reduzir as questões a duas dimensões, a representação matricial acaba por não capturar aspectos relevantes das transações comerciais contemporâneas, tais como: os negócios realizados através de redes de empresas (Dubois e Pendersen, 2002); a interdependência entre produtos (Terpend et al., 2011); e o conceito de vantagem competitiva e sustentável nos relacionamentos interfirmas (Pagell e Wu, 2009). 
Alguns autores, têm utilizado ideias básicas de Kraljic para o desenvolvimento de modelos similares, embora existam mais semelhanças do que diferenças em comparação com a matriz original de Kraljic. Alguns destes métodos mais aceitos na literatura são os de Hadeler \& Evans (1994), Olsen \& Ellram (1997) e Bensaou (1999). Porém, existem diversas aplicações do modelo de Kraljic com alterações, como o envolvimento dos fornecedores no desenvolvimento de produtos (Wynstra, 1998), seleção de fornecedores (De Boer, 1998), desenvolvimento de fornecedores (Handfield et al., 2000), compras baseadas pela internet de itens MRO (Croom, 2000), especificação de processos (Nelore e Soderquist, 2000), facilitação de processo interno de mudança (Axelsson et al, 2000) e desenvolvimento de competências inter-organizacionais (Moller e Momme, 2000) (Gelderman e Van Weele,2002).

\subsection{Sustentabilidade}

O tema sustentabilidade tem apresentado crescente interesse entre pesquisadores acadêmicos. Sua importância se deve principalmente à atenção despertada face às mudanças climáticas causadas pela ação predatória do homem no meio ambiente causando uma emergência planetária. Finalmente se reconhece o preço de fatores como o meio ambiente, o impacto sobre as comunidades e a longevidade dos funcionários, o que pode significar uma visão mais ampla de sustentar a lucratividade da empresa ao longo do tempo (Bacha et al.,2010). Com isso, o tema sustentabilidade tem apresentado impactos nas estratégias das empresas. São cada vez mais cobradas demonstrações de que a empresa tem um foco sustentável. Esta cobrança é feita tanto pela sociedade como pelos seus clientes corporativos, governos, dentre outros (Sgasrbi et al, 2008).

De acordo com Sgarbi et al. (2008), os primeiros estudos teóricos sobre a sustentabilidade iniciaram-se no campo das ciências ambientais e ecológicas, trazendo à discussão contribuições de diferentes disciplinas, tais como Economia, Sociologia, Filosofia, Política e Direito. No entanto, a sustentabilidade ambiental passou a ocupar lugar de importância no debate acadêmico e político, sobretudo a partir do final dos anos 1960. Porém, nas duas últimas décadas surgiu a emergência do discurso da sustentabilidade como a expressão dominante no debate que envolve as questões de meio ambiente e de desenvolvimento social e 
econômico em sentido amplo. Segundo Lacy (2010), foi lançado em 2010, em Nova York, o maior estudo de sustentabilidade corporativa, publicado pela United Nations Global Compact e pela Accenture Sustainability Services. Neste estudo foram entrevistados cerca de 1.000 executivos, líderes empresariais e da sociedade civil. O levantamento indica que o compromisso com as questões ambientais, sociais e de governança tornou-se significativo: 93\% dos CEOs (Chief Executive Officers) veem a sustentabilidade como fundamental para o sucesso da sua empresa, mostrando que houve mudança na mentalidade desde a última pesquisa, em 2007, quando a sustentabilidade estava começando a reformular as regras dos negócios globais.

Para Almeida (2002), neste novo cenário os empresários tornam-se cada vez mais aptos a compreender e participar das mudanças estruturais na relação de forças nas áreas ambiental, econômica e social. Além disso, o desenvolvimento sustentável, consequência da implantação da sustentabilidade, introduz uma dimensão ética e política que considere o desenvolvimento como um processo de mudança social, com consequente democratização do acesso aos recursos naturais e distribuição equitativa dos custos e benefícios do desenvolvimento. De acordo com Donaire (1999), o desenvolvimento sustentável, além de equidade social e equilíbrio ecológico, apresenta como terceira vertente principal, o desenvolvimento econômico. Esta induz um espírito de responsabilidade comum como processo de mudança, no qual a exploração de recursos materiais, os investimentos financeiros e as rotas do desenvolvimento tecnológico deverão adquirir sentidos harmoniosos. Neste sentido, o desenvolvimento da tecnologia deverá ser orientado para metas de equilíbrio com a natureza e de incremento da capacidade de inovação dos países em desenvolvimento, e o progresso será entendido como fruto de maior riqueza, maior benefício social e equilíbrio ecológico.

Portanto, a sustentabilidade desponta como um vetor estratégico fundamental para as organizações. Entretanto, para que as organizações alcancem algum tipo de vantagem neste aspecto sustentável, será necessário que desenvolvam ações sustentáveis passíveis de mensuração, ou seja, a adoção, a implementação e o relato da existência dos indicadores de sustentabilidade, perceptíveis pelos grupos de interesses da organização (stakeholders). A comprovação deste aspecto pode ser constatada pelos dados divulgados por 
relatórios de sustentabilidade que avaliam o "grau" de sustentabilidade das organizações, semelhante a certificações e, apesar da existência de diversos sistemas relacionados à mensuração da sustentabilidade, o Global Reporting Initiative - GRI, vem se tornando o mais utilizado (Rocha, 2012). O GRI foi criado com a intenção de padronizar e melhorar a qualidade dos relatórios de sustentabilidade que começaram a ser gerados sob vários formatos em todo o mundo (Tutillo, 2012).

\subsubsection{Evolução do Conceito}

Silva (2009) explica que o interesse por sustentabilidade se fortificou durante a década de 1980, a partir da conscientização dos países em descobrir formas de promover o crescimento sem destruir o meio ambiente e sem sacrificar o bem-estar das futuras gerações. Desde então, o termo se transformou em cenário para causas sociais e ambientais, principalmente nos negócios, onde prevalece a idéia da geração de lucro para os acionistas, ao mesmo tempo em que protege o meio ambiente e melhora a qualidade de vida das pessoas com as quais as empresas mantêm interações. A partir de 1992, na Conferência das Nações Unidas sobre Meio Ambiente e Desenvolvimento, reconheceu-se que as empresas têm um papel extremamente relevante pois através de uma prática empresarial sustentável, elas podem provocar mudanças de valores e de orientação em seus sistemas operacionais, ficando engajadas à idéia de desenvolvimento sustentável e preservação do meio ambiente.

Atualmente, há consenso entre os pesquisadores de que o conceito de sustentabilidade deve ser analisado de forma abrangente, pois é uma questão complexa com diversas abordagens (Kato, 2008). Existem diferentes correntes de pensamento em relação aos enfoques de sustentabilidade. De maneira geral, as definições procuram integrar viabilidade econômica com prudência ecológica e justiça social, nas três dimensões conhecidas como Tripple Bottom Line. O desenvolvimento econômico refere-se à geração de riqueza, a proteção ambiental diz respeito aos impactos no sistema natural e social e a inclusão social aborda os problemas relacionados com a má distribuição de rendimentos, saúde e oportunidades (Almeida, 2002; Moura, 2002). 
A definição do termo sustentabilidade tem sido assunto de debates acirrados no meio acadêmico, empresarial e governamental, tanto no Brasil como nas demais nações do mundo, em vista das questões socioambientais serem cobradas principalmente daqueles que se utilizam dos recursos naturais e do meio social para permanecerem e se perpetuarem em mercado competitivos (Lang, 2009). O termo sustentabilidade remete ao vocábulo "sustentar", no qual a dimensão longo prazo se encontra incorporada. Há necessidade de encontrar mecanismos de interação nas sociedades que ocorram em relação harmoniosa com a natureza. "Numa sociedade sustentável, o progresso é medido pela qualidade de vida (saúde, longevidade, maturidade psicológica, educação, ambiente limpo, espírito comunitário e lazer criativo) ao invés de puro consumo material” (Ferreira, 2005).

Vale ressaltar que, segundo Bacha et al. (2010), ao falar de sustentabilidade deve-se considerar que há necessidade de se dispor de objetividade ao tema desejado, já que foram encontradas nos trabalhos analisados várias temáticas: sustentabilidade socioambiental, sustentabilidade na agricultura, sustentabilidade da produção da indústria cultural, sustentabilidade política, sustentabilidade financeira, sustentabilidade da comunicação, sustentabilidade do turismo, sustentabilidade do crescimento turístico, sustentabilidade planetária, sustentabilidade empresarial, sustentabilidade da marca, sustentabilidade social, ambiental e econômica, sustentabilidade da soja transgênica, sustentabilidade da arquitetura, sustentabilidade do milênio, sustentabilidade de aterro sanitário, indicadores de sustentabilidade, sustentabilidade do recurso, sustentabilidade do meio ambiente, sustentabilidade do sistema INSS (Instituto Nacional do Seguro Social), sustentabilidade de transportes, sustentabilidade de ONGS (Organizações não Governamentais), sustentabilidade do empreendimento, sustentabilidade ambiental da cidade, sustentabilidade ecológica e sustentabilidade física e social. Para Silva (2009), a sustentabilidade, em termos econômicos, prevê que as organizações têm que ser economicamente viáveis, face ao seu papel na sociedade e que este deve ser cumprido levando em consideração o aspecto da rentabilidade, dando retorno ao investimento realizado pelo capital privado. Do ponto de vista social, a organização deveria proporcionar boas condições de trabalho e, em termos ambientais, a empresa deveria pautar-se pela ecoeficiência dos seus processos produtivos, oferecendo condições para o desenvolvimento de uma cultura ambiental organizacional, adotando-se uma postura de responsabilidade 
ambiental e buscando a não contaminação de qualquer tipo do ambiente natural. Seria importante para as empresas se adequarem a sustentabilidade, procurar participar de todas as atividades propostas pelas autoridades governamentais locais e regionais no que diz respeito ao meio ambiente.

\subsubsection{Dimensões da Sustentabilidade}

Nesta seção são discutidas as dimensões da sustentabilidade baseadas no Triple Bottom Line.

- Sustentabilidade Social

Nesta esfera da sustentabilidade, a atenção dada é ao ser humano, como componente do ambiente em que está inserido, atendo-se à preocupação com o seu bem-estar, qualidade de vida e sua condição perante a sociedade em geral. Dessa forma, uma empresa que busca a sustentabilidade social é aquela que atinge seus resultados de lucro e liquidez sem perder de vista o seu papel de geração de empregos, pagamento de impostos e de gestão ética (Melo Neto; Brennand, 2004).

O Conselho de Negócio Mundial para o Desenvolvimento Sustentável (WBCSD) define a responsabilidade social integrada como sendo o compromisso do negócio para contribuir com o desenvolvimento econômico sustentável, trabalhando com empregados, com suas famílias, com a comunidade local e com a sociedade, buscando melhorar a qualidade de vida do ambiente onde atua. Ser socialmente responsável não significa que uma companhia deva abandonar sua tarefa econômica preliminar, nem significa que as companhias socialmente responsáveis não possam ser tão lucrativas quanto outras companhias menos responsáveis. Nesta dimensão, as empresas devem avaliar os impactos de seu negócio no sistema social onde operam. A performance social é abordada por meio da análise do impacto da organização sobre as suas partes interessadas colaboradores, parceiros, fornecedores, consumidores/clientes, comunidade e sociedade em geral (Karna et al., 2003).

Para ilustrar a importância do tema, pode-se citar o caso da ISO que, reconhecendo a importância que a responsabilidade social vem ganhando em todo o mundo, a partir de 2001 engajou-se no sentido de produzir uma norma internacional sobre a responsabilidade social. Formou-se, então, o Grupo de Trabalho (GT) de elaboração da ISO 26000, liderado conjuntamente por um país 
desenvolvido e outro em desenvolvimento, numa decisão considerada histórica. As entidades escolhidas para liderarem o processo foram o Instituto Sueco de Normalização (Swedish Standards Institute -SIS) e a ABNT. Ao brasileiro Jorge Cajazeira, gerente de excelência corporativa da Suzano Papel e Celulose, coube a presidência do GT (Ursini e Serguishi2005). De acordo com Moynier et al. (2013), a norma ISO 26000:2010 é uma clara evidência do reconhecimento da importância do exercício da responsabilidade social pelo mundo dos negócios. A norma ISO 26000:2010 orienta as organizações quanto às práticas de responsabilidade social e estabelece um entendimento comum, universal, de modo a tornar-se ser cada vez mais reconhecida como referência no aprimoramento na gestão responsável dos negócios. Dentre as vantagens das práticas da responsabilidade social, destacam-se os benefícios mercadológicos e de imagem, pois a repercussão ocasionada pela postura politicamente correta é uma forma de manter a sobrevivência da empresa, devido à sua imagem pública favorável. Uma organização socialmente responsável favorece suas relações com os stakeholders e promove uma exposição na mídia espontânea, fazendo com que seus produtos (ou serviços) e sua marca ganhem maior visibilidade e aceitação na intenção da compra

- Sustentabilidade Ambiental

Para Andrade et al. (2000), a sustentabilidade ambiental é o exame e a revisão das operações de uma empresa da perspectiva da ecologia, sendo motivada por uma mudança nos valores da cultura empresarial, evoluindo da dominação para a parceria, da ideologia do crescimento econômico para a ideologia da sustentabilidade ambiental. Ainda para os autores, a consciência ecológica no Brasil está "abrindo caminho para o desenvolvimento de novos produtos, novas oportunidades de negócios e novos mercados de trabalho, não só no setor industrial como também no setor de serviços".

No processo contemporâneo de administração, a busca pela utilização consciente dos recursos naturais deixou de ser uma virtude e passou a ser uma obrigação, ou melhor, um dever organizacional. A preservação dos espaços utilizados pela organização não devem ser entendidos como os limites de atuação das organizações, pois ações que motivem a preservação consciente da sociedade tornam-se também uma função da empresa que deverá atingir, cada vez mais, a 
comunidade global. Resumidamente, sustentabilidade ecológica significa ampliar a capacidade do planeta através da utilização do potencial encontrado nos diversos ecossistemas, ao mesmo tempo em que se mantém um nível mínimo de deterioração dos mesmos. Deve-se reduzir a utilização de combustíveis fósseis, diminuir a emissão de substâncias poluentes, adotar políticas de conservação de energia e de recursos, substituir recursos não renováveis por renováveis e aumentar a eficiência em relação aos recursos utilizados (Sachs, 1997).

\section{- Sustentabilidade Econômica}

De acordo com Galeotti (2004),o processo de industrialização introduziu impactos severos no ambiente e no desenvolvimento sustentável. A industrialização contribuiu para o crescimento econômico, acelerando mudanças nas estruturas, difundiu o capital e a tecnologia e, também, acabou por ampliar falhas do mercado e distorções da política. Desta forma, aumentou os danos ambientais e desconsiderou os aspectos sociais. A globalização agiu como um motor, melhorando o crescimento econômico internacional em algumas indústrias e setores, e ao mesmo tempo, reduziu o crescimento econômico em outros países, resultando em depreciação, pobreza-induzida do recurso e na degradação ambiental As relações econômicas no âmbito mundial, afetam o ambiente e o desenvolvimento sustentável de diversas maneiras e através de várias vertentes. Ainda de acordo com o autor, o aumento da integração econômica promove o crescimento econômico dos envolvidos, que passam a usar mais os recursos naturais, carregando o planeta com emissões de gases e, também, com a poluição que aumenta significativamente. Sendo assim, muitos veem a globalização econômica como um inimigo do processo de sustentabilidade em equilíbrio harmônico. Por outro lado, outros veem na difusão do comércio internacional, das finanças, do investimento e da tecnologia, uma maneira de promover um desenvolvimento sustentável a todos os países do mundo

Esta dimensão abrange todos os aspectos das interações econômicas que podem existir entre uma organização e suas partes interessadas, incluindo os resultados tradicionalmente apresentados nos balanços financeiros. No entanto, no contexto do desenvolvimento sustentável, a prioridade não é apenas para indicadores que informam aos acionistas à direção sobre a rentabilidade, mas, sobretudo, indicadores que vão permitir avaliar como as partes interessadas são 
afetadas pelas atividades da empresa. A adoção dos conceitos do triple bottom line, principalmente das duas dimensões inicialmente citadas, só trazem resultados se não comprometerem a saúde financeira do empreendimento (Lima, 2009).

A sustentabilidade deve exigir que as organizações atendam às necessidades essenciais de todos, tanto aumentando o potencial de produção, quanto primando pelo bem estar social (Souza, 2000). A Tabela 5 resume as esferas expostas nesta seção.

Tabela 5-Três Dimensões do Desenvolvimento Sustentável: Principais Pontos Fonte : Adaptado de Montibeller-Filho (2001)

\begin{tabular}{|c|c|c|}
\hline Dimensão & Componentes & Objetivos \\
\hline Social & $\begin{array}{l}\text { - Componentes de postos de trabalho que permitiam a obtenção } \\
\text { de renda individual adequada (à melhor condição de vida: à maior } \\
\text { qualificação profissional). } \\
\text { - Desenvolvimento da comunidade afetada pelas atividades } \\
\text { (educação, saúde, empregos) } \\
\text { - Produção de bens dirigida prioritariamente às necessidades } \\
\text { básicas sociais. }\end{array}$ & $\begin{array}{l}\text { Redução das } \\
\text { desigualdades } \\
\text { sociais }\end{array}$ \\
\hline Econômica & $\begin{array}{l}\text { - Fluxo permanente de investimentos públicos e privados (estes } \\
\text { últimos com especial destaque para o cooperativismo). } \\
\text { - Manejo eficiente dos recursos. } \\
\text { - Absorção, pela empresa, dos custos ambientais. }\end{array}$ & $\begin{array}{l}\text { Aumento da } \\
\text { produção e da } \\
\text { riqueza social }\end{array}$ \\
\hline Ambiental & $\begin{array}{l}\text { - Produzir respeitando os ciclos ecológicos dos ecossistemas. } \\
\text { - Prudência no uso de recursos naturais não renováveis. } \\
\text { - Prioridade à produção de biomassa e à industrialização de } \\
\text { insumos naturais renováveis. } \\
\text { - Redução da intensidade energética e aumento da conservação } \\
\text { de energia. } \\
\text { - Tecnologias e processos produtivos de baixo índice de resíduos. } \\
\text { - Cuidados ambientais. }\end{array}$ & $\begin{array}{l}\text { Melhoria da } \\
\text { qualidade do meio } \\
\text { ambiente e } \\
\text { preservação das } \\
\text { fontes de recursos } \\
\text { energéticos e } \\
\text { naturais para as } \\
\text { próximas gerações }\end{array}$ \\
\hline
\end{tabular}

\subsubsection{Desenvolvimento Sustentável e Estratégia Empresarial}

Como descrito, o conceito de desenvolvimento sustentável é resultado de um relativamente longo processo histórico de reavaliação crítica da relação existente entre a sociedade civil e seu meio natural. Por se tratar de um processo contínuo e complexo, observa-se hoje que existe uma variedade de abordagens que procura explicar o conceito de sustentabilidade. Esta variedade pode ser mostrada pelo enorme número de definições relativas ao conceito.

A partir do Relatório Brundtland a ênfase do conceito de sustentabilidade desloca-se do elemento ambiental para o elemento humano, gerando um equilíbrio 
entre as dimensões econômica, ambiental e social. Este documento, elaborado a partir da World Commission on Environment and Development (WCED, 1987), traz uma das definições mais conhecidas deste conceito, afirmando que o desenvolvimento sustentável é aquele que atende às necessidades das gerações presentes sem comprometer a possibilidade das gerações futuras atenderem suas próprias necessidades. Para assegurar a sustentabilidade do desenvolvimento devem-se considerar os fatores social, ecológico e econômico, dentro das perspectivas de curto, médio e longo prazo. Ennis-Reynolds (2002) afirma que a política para o desenvolvimento sustentável apoia-se em quatro alvos principais:

a) progresso social que reconhece as necessidades de todos;

b) proteção eficaz do ambiente;

c) uso prudente dos recursos naturais;

d) manutenção dos níveis elevados e estáveis do crescimento econômico e dos níveis de emprego.

No entender de Crawford (2004), a definição de desenvolvimento sustentável depende dos valores sociais sustentáveis e culturais fundamentais, enfatizando o valor crítico de recursos naturais e a urgência com que o ambiente necessita de uma diminuição na degradação. Assim, o termo desenvolvimento sustentável pode ser visto como palavra-chave desta época, sendo que existem para este conceito inúmeras definições.

Um dos temas relacionados ao desenvolvimento sustentável mais em foco nos dias atuais é a sustentabilidade empresarial devido a sua relação com a obtenção de vantagem competitiva. Hoje, a sustentabilidade nos negócios é encarada não como uma iniciativa ambiental, e sim como estratégia empresarial que gera valor a partir da busca de melhores resultados sociais e ambientais. As empresas estão procurando inserir o tripé da sustentabilidade (Tripple Bottom Line) na estratégia e gestão de seus negócios e, com isso, surgem novos modelos de negócios que visam o equilíbrio entre o capital natural e o humano como, por exemplo, o desenvolvimento de tecnologias limpas (Bm\&Fbovespa,2010). Assim, surge um novo conceito de empresa, orientada para práticas de sustentabilidade, cuja principal característica é o esforço para reduzir seus impactos ambientais e sociais através de adaptação de seus produtos, processos e estruturas organizacionais. As empresas devem realizar seus negócios por meio de atividades que respeitem o meio ambiente (Schaltegger et al., 2003). 
O princípio da sustentabilidade nas empresas, como observado por Porter e Kramer (2006), aparece frequentemente invocando o triple bottom line, que consiste na busca da continuidade no mercado e no crescimento da organização, a partir de sua viabilidade econômica, além da coexistência harmônica com o meio ambiente e sociedade. Nesse novo contexto, segundo um estudo da Confederação Nacional da Indústria (CNI, 2011), o bom desempenho da empresa não se associa somente à sua capacidade produtiva, de inovação e de participação no mercado. Elementos de sucesso como diferencial de preço, qualidade e fidelidade à marca, podem ser impactados pelo não engajamento no tema sustentabilidade corporativa. A proteção ambiental passa a fazer parte dos objetivos de negócios, e o meio ambiente não é mais encarado como um adicional de custo, mas como uma possibilidade de lucro em um quadro de ameaças e oportunidades para a empresa (Sanches, 2000).

\subsection{Sustentabilidade em Compras}

À medida que os aspectos ambientais, sociais e econômicos dos produtos e serviços se tornam melhor compreendidos e divulgados, surge uma reação natural da sociedade exigindo que as empresas se comportem de maneira sustentável. As crescentes exigências dos fornecedores, acionistas, governo e colaboradores constituem importantes forças motrizes para as organizações implementarem práticas em suas atividades que sejam ambientalmente e socialmente responsáveis. As empresas que perceberem isto e trabalharem junto a seus fornecedores, no sentido de encontrarem soluções mais ecológicas e socialmente responsáveis, estarão criando um diferencial competitivo em relação a seus concorrentes. Apesar da existência de trabalhos importantes nesta área (Bowen et al., 2001; Meehan e Bryden, 2011; Pagell et al. 2010), Compras Sustentáveis é um tema que está em estágio inicial. Trabalhos que visem determinar como princípios ligados ao desenvolvimento sustentável podem ser integrados às estratégias de Compras são necessários (Meehan e Bryden, 2011).

\subsubsection{Definição}

De acordo com Santos et al. (2010), as Compras Sustentáveis são uma solução para integrar considerações ambientais e sociais em todas as fases do 
processo de compra e contratação, visando reduzir impactos sobre a saúde humana, o meio ambiente e os direitos humanos. A prática destas compras permite atender as necessidades específicas dos consumidores finais através da compra do produto/serviço que oferece o maior número de benefícios para o ambiente e para a sociedade. São também conhecidas como eco-aquisições, compras ambientalmente amigáveis, consumo responsável e licitação positiva.

Além disso, para se entender o conceito de compra sustentável, é necessário visualizar as três dimensões de sustentabilidade do Tripple Bottom Line, afetadas pela função de Compras, além do impacto que a área exerce sobre elas. $\mathrm{O}$ conceito estabelecido por Schneider \& Wallenburg (2012) engloba as esferas econômica, social e ambiental ante um grande corpo acadêmico que explora os pilares de forma independente e isolada, estudando apenas aspectos isolados do Tripple Bottom Line. A implementação da compra sustentável envolve o balanceamento das diferentes prioridades que às vezes podem competir entre si no estudo das dimensões do Tripple Bottom Line. Para QGCP (Queensland Government Chief Procurement Office, Sustainable Procurement, 2012), as três dimensões podem ser relacionadas a compras como mostrado na Tabela 6 abaixo: 
Tabela 6- Dimensões das Compras Sustentáveis

Fonte: Adaptado de QGCPO (2012)

\begin{tabular}{|c|c|c|}
\hline Dimensão & Necessidade da Dimensão & Ações Desejáveis \\
\hline $\begin{array}{l}\overline{\bar{\pi}} \\
\text { கூ } \\
\text { க) }\end{array}$ & $\begin{array}{l}\text { Indicar que uma organização } \\
\text { examinou sua cadeia de } \\
\text { suprimentos garantindo que ela seja } \\
\text { socialmente responsável e ética, ou } \\
\text { seja, que ela não faz mal em } \\
\text { relação aos indicadores sociais, tais } \\
\text { como as condições de trabalho e os } \\
\text { direitos humanos dos } \\
\text { trabalhadores. }\end{array}$ & $\begin{array}{l}\text {-Promover práticas justas de trabalho - salários justos, } \\
\text { igualdade, diversidade da força de trabalho, prevenção } \\
\text { contra o trabalho escravo. } \\
\text {-Promover o bem-estar da força de trabalho (por exemplo, } \\
\text { saúde e segurança e filiação sindical). } \\
\text {-Criação de oportunidades de emprego e formação } \\
\text { (particularmente entre os grupos desfavorecidos como as } \\
\text { pessoas com deficiência ou doença mental, migrantes, } \\
\text { indígenas) proporcionando assim, a inclusão social. } \\
\text {-Sustentabilidade local - construção e manutenção de } \\
\text { comunidades fortes, saudáveis, apoio a inclusão social e } \\
\text { melhoria do bem-estar dos moradores da região por meio } \\
\text { da geração de emprego local e do desenvolvimento de } \\
\text { fornecedores locais. }\end{array}$ \\
\hline 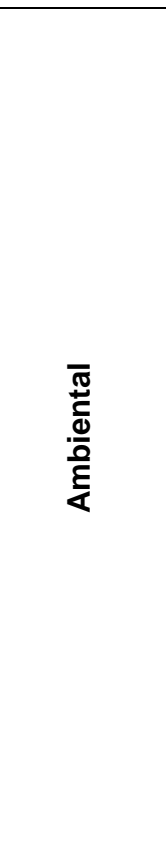 & $\begin{array}{l}\text { Contratação de bens e serviços } \\
\text { ambientalmente preferíveis. Estes } \\
\text { são definidos como aqueles que } \\
\text { têm impacto menor sobre o meio } \\
\text { ambiente durante seu ciclo de vida. } \\
\text { As principais questões ambientais } \\
\text { que precisam ser considerados ao } \\
\text { longo do ciclo de vida do produto / } \\
\text { serviço incluem: o consumo de } \\
\text { energia e o tipo de energia utilizada; } \\
\text { uso da água e impactos na } \\
\text { qualidade da água; utilização de } \\
\text { recursos, incluindo o uso de } \\
\text { recursos não renováveis; volume e } \\
\text { tipo de resíduos gerados; opções } \\
\text { de fim de vida, por exemplo, } \\
\text { reciclagem, recuperação de } \\
\text { recursos impacto no habitat natural; } \\
\text { ruído, poluentes e emissões } \\
\text { gerados. }\end{array}$ & $\begin{array}{l}\text {-Melhoria da qualidade do ar, reduzindo ou eliminando as } \\
\text { emissões para o ar (por exemplo, gases de efeito estufa). } \\
\text {-Redução do uso de água e melhoria de sua qualidade, } \\
\text { reduzindo ou eliminando emissões para a água (por } \\
\text { exemplo, a poluição química dos cursos de água). } \\
\text {-Melhoria da qualidade do solo, reduzindo ou eliminando } \\
\text { emissões para o solo (por exemplo, adubos químicos). } \\
\text { - Redução da demanda de matérias-primas e recursos } \\
\text { naturais. } \\
\text {-Redução do uso de energia (por exemplo, eficiência } \\
\text { energética, uso de energia renovável). } \\
\text {-Redução da energia emitida (por exemplo, calor, } \\
\text { radiação, vibração, ruído). } \\
\text {-Redução de resíduos e subprodutos (por exemplo, } \\
\text { reciclagem e prevenção de resíduos). }\end{array}$ \\
\hline 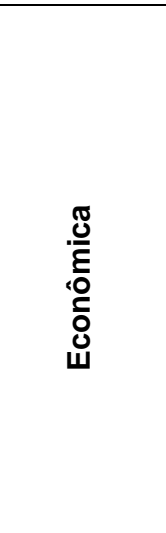 & $\begin{array}{l}\text { Redução de custos através de: } \\
\text {-bens e serviços que são mais } \\
\text { eficientes para operar reduzindo os } \\
\text { custos operacionais (incluindo } \\
\text { energia, água e tempo). } \\
\text {-desafio a demanda na fonte, de } \\
\text { modo a evitar compras em excesso. } \\
\text {-aumentar a eficiência da cadeia de } \\
\text { suprimentos e desenvolver a } \\
\text { competitividade do mercado, } \\
\text { provocando a capacidade de } \\
\text { inovação dos fornecedores. }\end{array}$ & $\begin{array}{l}\text {-Criação de empregos (por exemplo, o uso de } \\
\text { fornecedores locais, a criação de mercados para os } \\
\text { produtos reciclados). } \\
\text {-Reduzir as barreiras de entrada (por exemplo, facilitando } \\
\text { a concorrência aberta). } \\
\text {-Fornecedores capazes de honrar seus compromissos } \\
\text { financeiros e contratuais não gerando impactos nos } \\
\text { produtos/serviços fornecidos. } \\
\text {-Acompanhamento das demandas solicitadas verificando } \\
\text { a real necessidade das mesmas evitando desperdícios. } \\
\text {-Redução dos custos associados ao ciclo de vida do } \\
\text { produto/serviço. }\end{array}$ \\
\hline
\end{tabular}




\subsubsection{Benefícios das Compras Sustentáveis}

As compras sustentáveis apresentam diversos benefícios, conforme exemplificado na Tabela 7.

Tabela 7- Benefícios das Compras Sustentáveis

Fonte: Adaptado de Procurement Sustentável (BCSD Portugal,2008)

\begin{tabular}{|c|c|}
\hline Organização & ade \\
\hline $\begin{array}{l}\text { Benefícios para os resultados: menor custo } \\
\text { operacional total; redução dos custos } \\
\text { associados à gestão dos resíduos; poupanças } \\
\text { relativas ao consumo de energia, água, } \\
\text { combustíveis etc. }\end{array}$ & $\begin{array}{l}\text { Economia mais forte: Contribui para o } \\
\text { desenvolvimento de mercado para os } \\
\text { produtos/serviços sustentáveis; Incentiva a inovação } \\
\text { através de criação de parceria com os fornecedores } \\
\text { no sentido de desenvolver produtos/serviços que } \\
\text { gerem menos impactos; Reduz custos energéticos e } \\
\text { com materiais, permitindo aumentar a disponibilidade } \\
\text { financeira para outros fins. }\end{array}$ \\
\hline $\begin{array}{l}\text { Redução de riscos: Cumprimento dos } \\
\text { requisitos legais; redução do risco de acidente } \\
\text { e consequentemente diminuição dos custos } \\
\text { diretos (seguradoras, saúde) e indiretos (perda } \\
\text { de produção, não cumprimento de prazos de } \\
\text { entrega); reduz a probabilidade de se comprar } \\
\text { produtos/serviços que gerem impactos } \\
\text { ambientais e sociais negativos. }\end{array}$ & $\begin{array}{l}\text { Ambiente mais saudável: Redução da produção de } \\
\text { resíduos; utilização das matérias primas de forma } \\
\text { mais eficiente; reduz ou elimina as emissões para o } \\
\text { ar e água; reduz o impacto ambiental de produtos e } \\
\text { serviços ao longo do seu ciclo de vida, com } \\
\text { benefícios reconhecidos a nível local e global. }\end{array}$ \\
\hline $\begin{array}{l}\text { Reforço da imagem: permite compreender e } \\
\text { satisfazer a necessidade dos stakeholders no } \\
\text { que diz respeito a sustentabilidade; demonstra } \\
\text { o compromisso da organização com uma } \\
\text { política de sustentabilidade e de } \\
\text { responsabilidade social; melhora as condições } \\
\text { de trabalho dos colaboradores e o ambiente } \\
\text { da comunidade envolvente através da redução } \\
\text { de emissões para o ar e para a água, } \\
\text { diminuição do consumo de recursos naturais e } \\
\text { promoção do desenvolvimento econômico } \\
\text { local. }\end{array}$ & $\begin{array}{l}\text { Aumento do bem estar social: Apoio aos } \\
\text { fornecedores que têm um forte compromisso com as } \\
\text { comunidades locais e grande responsabilidade social } \\
\text { e ambiental; Promove o desenvolvimento de } \\
\text { fornecedores locais; Negocia com fornecedores que } \\
\text { cumprem as convenções internacionais relativos à } \\
\text { condição de trabalho; Garantia da segurança no } \\
\text { trabalho de todos os colaboradores. }\end{array}$ \\
\hline
\end{tabular}




\subsubsection{Modelo de Portfólio com a dimensão de sustentabilidade}

De acordo com Pagell et al. (2010), ocorreram muitas mudanças na gestão de suprimentos das empresas desde que Kraljic propôs seu modelo de portfólio de compras, em 1983. Sustentabilidade é um tema não tratado originalmente pelo modelo, mas uma preocupação que atinge muitas empresas atualmente. Quando inquietações sociais e ambientais são importantes direcionadores das decisões de fornecimento, a categorização de fornecedores que originalmente enfatizava os aspectos econômicos torna-se inadequada (Amindoust et al., 2012).

De acordo com Elkington (1998), os gestores das cadeias de suprimentos não estão baseando suas decisões e estratégias apenas nas variáveis indicadas no modelo de Kraljic (1983), como custos e impactos na rentabilidade econômica da organização. Aspectos oriundos da sustentabilidade - destacados no modelo do Tripple Bottom Line, como os impactos no meio ambiente e na sociedade começam a ser adotados paralelamente às considerações econômicas. A preocupação com a continuidade dos negócios e relação com a base de fornecimento é fundamental para o gerenciamento sustentável de uma cadeia de suprimentos-SSCM (Sustainable Supply Chain Management). Ainda de acordo com o autor, a ideia de continuidade deve ter grande importância nas ações sociais e ambientais do fornecedor. Ela deve se estender em toda a cadeia de suprimentos, não apenas na primeira camada de fornecedores. A Tabela 8 apresenta cinco práticas focadas na continuidade da base de suprimentos. Esta continuidade está mais preocupada com a sobrevivência do negócio no longo prazo do que apenas a maximização dos resultados financeiros. Ela está alinhada com a visão do SSCM, com a prosperidade comum de todos os envolvidos, com o Tripple Bottom Line e com o desenvolvimento sustentável. Ou seja, além do lucro, os resultados da empresa devem estar focados nas pessoas e no planeta. 
Tabela 8- Prática de Continuidade da Base de Suprimentos

Fonte: Pagell, et al. (2010)

\begin{tabular}{|c|l|}
\hline Prática de Continuidade & \multicolumn{1}{|c|}{ Descrição } \\
\hline Descommoditização & $\begin{array}{l}\text { Tratamento de um fornecedor e/ou cadeia de suprimento que prover uma } \\
\text { commodity (itens alavancados ou não críticos: competição prioritariamente } \\
\text { em preço) como fornecedor de item estratégico. Os compradores } \\
\text { estabelecem contratos de longo prazo e pagam um preço acima do mercado } \\
\text { por itens que são usualmente comprados em um mercado de concorrência } \\
\text { perfeita. }\end{array}$ \\
\hline $\begin{array}{c}\text { Desenvolvimento } \\
\text { tradicional do fornecedor }\end{array}$ & $\begin{array}{l}\text { Treinar os fornecedores para serem os melhores para a empresa } \\
\text { compradora. }\end{array}$ \\
\hline Reduzir os riscos de & $\begin{array}{l}\text { Ajudar os fornecedores a diminuir alguns ou todos os riscos associados ao } \\
\text { fornecimento de produtos e serviços mais sustentáveis. }\end{array}$ \\
\hline Desenvimentos & $\begin{array}{l}\text { Treinar os fornecedores para serem os melhores no setor. } \\
\text { tradicional de fornecedor }\end{array}$ \\
\hline Transparência & $\begin{array}{l}\text { Todos os membros da cadeia fazem uma prestação de conta completa do } \\
\text { fluxo do dinheiro para a origem. }\end{array}$ \\
\hline
\end{tabular}

As razões para as práticas de continuidade na base de fornecimento podem ter uma natureza de curto ou longo prazo. No curto prazo, podem ser devidas a uma diferenciação momentânea da commodity (um fornecedor de madeira retirada de florestas que pratica o reflorestamento, por exemplo). Entretando, a partir do momento que esta característica ou prática torna-se plenamente consolidada, diversos fornecedores neutralizam esta diferença e o produto volta a condição de commodity. No longo prazo, um fornecedor de commodity deve ser analisado como agente que, além de potencializar resultados financeiros, podem viabilizar resultados sociais e ambientais. Contudo, esses proventos aumentam suas possibilidades de melhoria com um relacionamento cooperativo de longo prazo entre comprador e fornecedor. A compreensão de algumas necessidades básicas de ambos só é possível com o relacionamento de longo prazo (Osiro, 2013).

Baseado nas práticas de continuidade na base de fornecimento encontrado nas empresas pesquisadas, Pagell et al. (2010) propuseram modificações no modelo de compra de Kraljic. Esta atualização considera aspectos sociais e ambientais nas dimensões da matriz, atendendo ao conceito do Tripple Bottom Line. Este modelo não é uma contraposição ao modelo proposto por Kraljic (1983), mas sim uma adaptação, visando atender às necessidades sustentáveis em termos de seleção de fornecedores. Ao invés de quatro categorias iniciais do 
modelo de Kraljic (1983), a revisão propõe seis categorias, com as maiores mudanças para os itens alavancados, conforme exposto na Figura 5 e na Tabela 9.

No eixo vertical da Figura 5, assim como na Tabela 9, pode-se verificar a mudança da dimensão "importância da compra" da matriz original de Kraljic para a dimensão "ameaça para os lucros, meio ambiente e sociedade", ou seja, o triple bottom line. Desta forma não apenas os aspectos financeiros devem ser analisados.

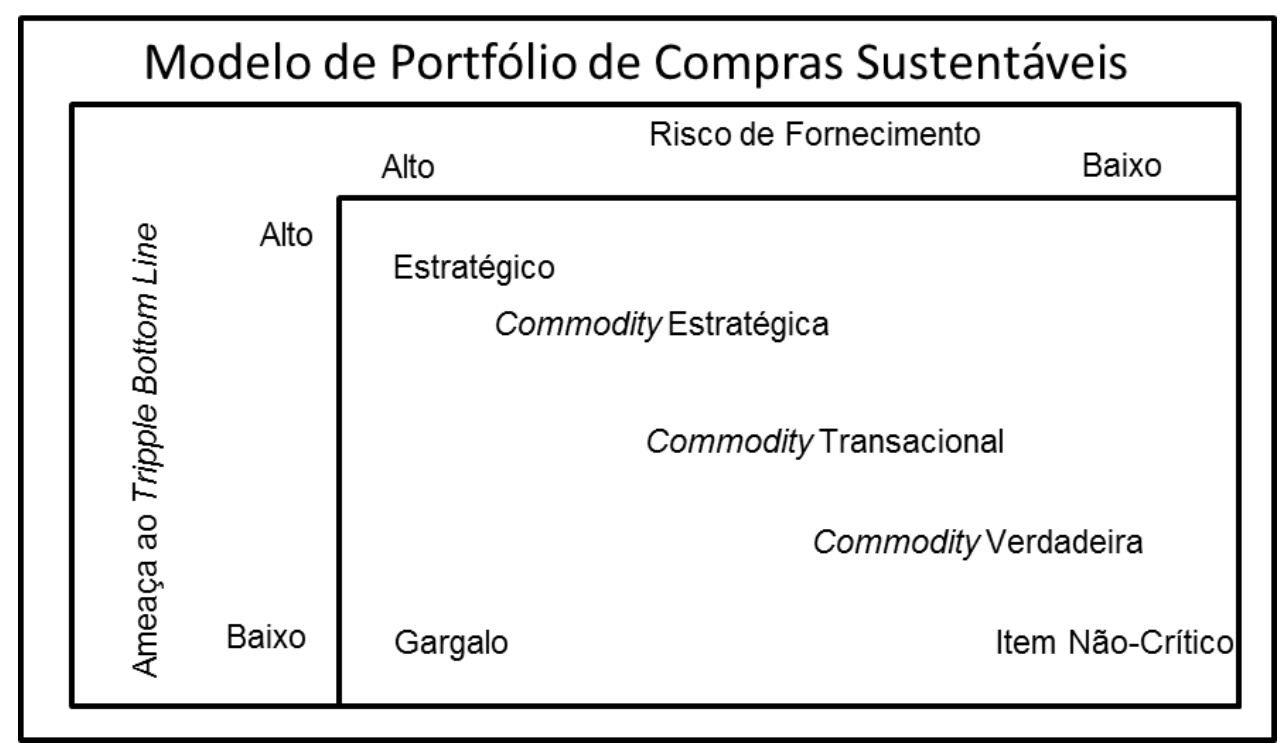

Figura 5- Matriz de Portfólio de Compras Sustentáveis Fonte: Pagell, et al. (2010)

As características de cada segmento no modelo de Pagell et al. (2010) são:

- Itens Estratégicos: A mudança nessa categoria está na sua importância, que não se restringe a aspectos econômicos, mas pode envolver elementos sociais e ambientais. Ou seja, um item estratégico tem um risco de suprimento alto e uma ameaça a qualquer um dos aspectos do Tripple Bottom Line também alto.

- Itens Gargalo: Não há mudanças. Os itens gargalo envolvem baixo impacto em qualquer dos elementos do Tripple Bottom Line, mas alto risco de suprimento. Devido a essa instabilidade no fornecimento, altos níveis de estoque de segurança e busca de novas fontes de suprimento são alternativas recomendadas na gestão.

- Commodity Verdadeira: Dentre as três novas categorias derivadas dos itens alavancados, esta é a mais semelhante a original. Ela possui importância em apenas um elemento do Tripple Bottom Line e um 
risco de suprimento baixo, de maneira a não fornecer grandes dificuldades na troca de fornecedor.

- Commodity Transitória: Derivada da categoria de itens alavancados, ela envolve as práticas de continuidade na base de fornecimento de natureza de curto prazo. Ou seja, o risco no fornecimento é provavelmente transitório, pois a diferenciação do fornecedor é momentânea. Em um prazo não muito longo, outros fornecedores seguirão o novo padrão e o produto voltará novamente à condição de commodity .

- Commodity Estratégica: Também derivada da categoria de itens alavancados, envolve as práticas de continuidade na base de fornecimento de longo prazo. Ou seja, o risco no fornecimento é estratégico, devido aos investimentos feitos pelo comprador no relacionamento com o fornecedor. Esses investimentos são realizados devido a elementos sociais e ambientais. Essa iniciativa minimiza as ameaças ao Tripple Bottom Line e cria novas oportunidades de um relacionamento duradouro, mas aumenta o risco de perda de investimento se houver a troca de fornecedor. Diferentemente dos itens estratégicos, neste item o risco no suprimento aumenta dadas às escolhas do comprador em investir em um fornecedor.

- Itens Não-Críticos: Não apresentam modificações em relação ao modelo de Kraljic. Nessa categoria, os riscos de suprimentos e as ameaças ao Tripple Bottom Line são baixos. O objetivo na gestão desta categoria é obter o menor custo de suprimento. 
Tabela 9- Categorias da Matriz de Portfólios Revisada Fonte: Pagell et al. ,2010.

\begin{tabular}{|c|c|c|c|c|}
\hline $\begin{array}{l}\text { Categoria } \\
\text { Kraljic }\end{array}$ & $\begin{array}{c}\text { Nova } \\
\text { Categoria }\end{array}$ & Risco de Fornecimento & $\begin{array}{c}\text { Ameaça para os lucros, } \\
\text { meio ambiente e sociedade }\end{array}$ & $\begin{array}{l}\text { É de curto } \\
\text { prazo? }\end{array}$ \\
\hline $\begin{array}{c}\text { Item } \\
\text { Estratégico }\end{array}$ & $\begin{array}{c}\text { Item } \\
\text { Estratégico }\end{array}$ & Alto & Uma alta pelo menos & Não \\
\hline $\begin{array}{c}\text { Item } \\
\text { Gargalo }\end{array}$ & Item Gargalo & Alto & Todas baixas & Não \\
\hline $\begin{array}{l}\text { Item não } \\
\text { crítico }\end{array}$ & $\begin{array}{l}\text { Item não } \\
\text { crítico }\end{array}$ & Baixo & Todas baixas & Não \\
\hline \multirow{3}{*}{$\begin{array}{c}\text { Item } \\
\text { Alavancado }\end{array}$} & $\begin{array}{l}\text { Commodity } \\
\text { Verdadeira }\end{array}$ & Baixo & Uma alta e outras baixas & Não \\
\hline & $\begin{array}{l}\text { Commodity } \\
\text { Transitória }\end{array}$ & $\begin{array}{l}\text { Atualmente alto devido a } \\
\text { assimetria de informação. } \\
\text { Retornará para o baixo. }\end{array}$ & Uma alta e outras baixas & Sim \\
\hline & $\begin{array}{l}\text { Commodity } \\
\text { Estratégica }\end{array}$ & $\begin{array}{c}\text { Comprador leva do baixo } \\
\text { para o alto }\end{array}$ & Uma alta pelo menos & Não \\
\hline
\end{tabular}

Conforme exposto, este modelo introduz os elementos sociais e ambientais nos modelos de portfólio de compras. Segundo os autores, com a adoção de princípios sustentáveis no processo de seleção, um menor número de fornecedores é utilizado. Relacionamentos mais próximos - com contratos mais longos, como foram destacados acima - para itens antes tratados como simples commodities, estão sendo adotados, o que tem como consequência esta redução.

O objetivo fundamental do modelo de Kraljic - explorar completamente a capacidade e o poder de barganha, com o objetivo de reduzir custos, riscos e obter uma adequada disponibilidade - foi igualmente analisado por Krause et al. (2009) no caso em que gestores visam construir uma Cadeia de Suprimentos Sustentável (Sustainable Supply Chain). Para analisar a incorporação dos aspectos sustentáveis, os autores valeram-se da teoria das prioridades competitivas. Uma prioridade competitiva é uma estratégia definida por uma organização, em paralelo à sua estratégia geral, para atuar num mercado específico (Hayes e Wheelwright, 1984). Eles sugerem que o desenvolvimento sustentável poderia ser uma nova prioridade competitiva, considerada conjuntamente com outras tradicionais prioridades competitivas: qualidade, custo, confiabilidade, pontualidade, flexibilidade e inovação. A proposta é incluir sustentabilidade como um critério chave de desempenho nos quatro quadrantes do modelo de Kraljic (1983) conforme a Figura 6. 


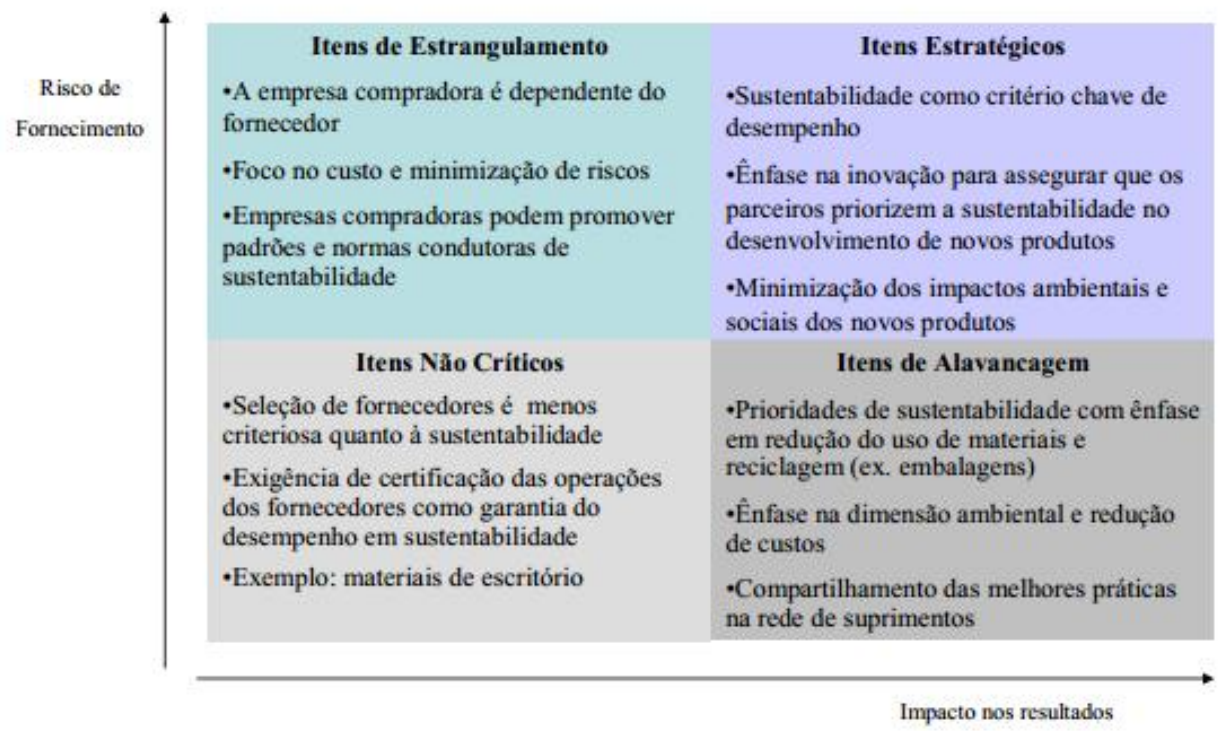

Figura 6- Matriz de Inclusão da Sustentabilidade nas Categorias do Modelo de Kraljic Fonte: Krause et al. (2009)

Para os itens considerados estratégicos, é importante focar nos aspectos ligados à inovação, para garantir que seus fornecedores considerem aspectos sustentáveis no desenvolvimento de seus produtos. Além disso, a colaboração e o compartilhamento de know-how neste caso são importantes para assegurar a minimização de impactos sociais e ambientais de novos produtos. Para os itens considerados alavancagem, uma ênfase na redução do consumo de insumos e no uso de materiais reciclados, por exemplo, ganha importância. Para os itens gargalo, a adoção de práticas sustentáveis é mais difícil, pois a organização compradora está numa situação de dependência. Nestes casos, a organização compradora pode incentivar a adoção de padronização e certificação nas organizações fornecedoras. Por fim, para os produtos não críticos, é proposta a adoção de simples critérios qualificadores de fornecedores, como a exigência de alguma certificação.

As conclusões de Krause et al. (2009) a partir da construção do modelo apresentado na Figura 6, indicam que as organizações irão demandar um nível de sustentabilidade de seus fornecedores de acordo com o tipo de componente/item exigido no momento da aquisição. Ao mesmo tempo, algumas empresas irão adotar a sustentabilidade de maneira unilateral, como parte de estratégia de negócios, enquanto outras serão coagidas a integrar a sustentabilidade por meio de clientes, fornecedores ou pela legislação. Algumas podem escolher focar seus 
esforços apenas nas dimensões ambiental e econômica e outras podem também inserir questões sociais e culturais como fatores de avaliação de desempenho. Porém, para as empresas que de fato incluem a sustentabilidade como parte da estratégia competitiva e corporativa, o nível de sustentabilidade é um critério de desempenho essencial para todos os quadrantes da matriz.

O foco do trabalho de Krause et al. (2009) é buscar compreender se a inserção de sustentabilidade no processo de compras de uma organização pode causar algum tipo de impacto na elaboração das estratégicas de compras, na relação e no desempenho dos fornecedores. Caso o impacto desta inserção seja positivo, a área de gerenciamento de compras deixaria de cumprir um papel de cunho operacional e passaria a representar um caráter estratégico, resultando na construção de uma nova área denominada gestão sustentável de suprimentos. A partir deste pressuposto, entende-se que as ações de compras que consideram os aspectos de sustentabilidade são elementos fundamentais para a criação e consolidação de cadeias de suprimentos sustentáveis. 


\section{Metodologia de Pesquisa}

Este capítulo tem como objetivo apresentar as técnicas de pesquisas para o desenvolvimento do presente trabalho.

A pesquisa do presente trabalho foi baseada em um estudo de caso. Segundo Gil (2007), o estudo de caso consiste no estudo profundo e exaustivo, com base empírica, de um ou poucos objetos, de maneira que permita seu amplo e detalhado conhecimento. $\mathrm{O}$ estudo de caso se aplica às situações em que há muito mais variáveis de interesse do que dados e, por isto, busca em várias fontes de dados, evidências cujas informações precisam convergir. Além disso, beneficia-se do desenvolvimento prévio de proposições teóricas que devem conduzir à coleta $\mathrm{e}$ à análise de dados (Yin, 2005).

$\mathrm{Na}$ estruturação do estudo de caso, Yin (2005) relata que existem pelo menos três grandes fases: a primeira envolve a escolha do referencial teórico sobre o qual se pretende trabalhar, a seleção dos casos e o desenvolvimento de protocolos para a coleta de dados (procedimentos a serem adotados para a coleta de dados, tais como: observação de campo, entrevistas, análise documental etc.). A segunda compreende a coleta e análise de dados, culminando com o relatório do caso. Nesta etapa são colhidas as evidências que comporão o material para o caso. A terceira fase abrange a análise dos dados obtidos à luz da teoria selecionada, interpretando os resultados.

Esta dissertação foi estruturada seguindo a abordagem de Yin (2005) para a elaboração do estudo de caso. Inicialmente, foram realizadas pesquisas bibliográficas sobre o tema em livros, artigos, teses e periódicos. Após a revisão da literatura, um panorama geral sobre o setor de mineração é realizado, mostrando a interface dos tópicos abordados no trabalho com o setor estudado. Em seguida, é apresentado o estudo de caso e, como fonte de informação e coleta de dados, considera um questionário estruturado e reunião com o grupo focal, para aplicação e avaliação do modelo de Pagell et al. (2010).

A pesquisa por meio do questionário tem por objetivo registrar informações dos especialistas da empresa sobre a amostra de itens de compra previamente definidos. Este questionário foi aplicado a um grupo focal, constituído por todos os profissionais da categoria analisada juntos, de modo que a resposta final fosse com base no consenso do grupo. Desta forma, mitiga-se o 
risco de se ter somente a percepção individual e consegue-se obter a percepção do conjunto de especialistas que atuam nesta categoria com o objetivo de ser possível a aplicação do modelo analisado. Para a aplicação do questionário, foram consultados como grupo focal, os 11 profissionais que atuam na categoria de movimentação interna. Na Figura 7, estão descritos os cargos e o tempo médio de atuação na categoria estudada dos profissionais alocados em cada um deles. Podese observar de acordo com o perfil exibido na Figura 7 que a Categoria de Movimentação Interna é composta por profissionais com mais de 1,5 anos de experiência em Suprimentos. Isto é devido principalmente a complexidade encontrada dentro desta categoria.

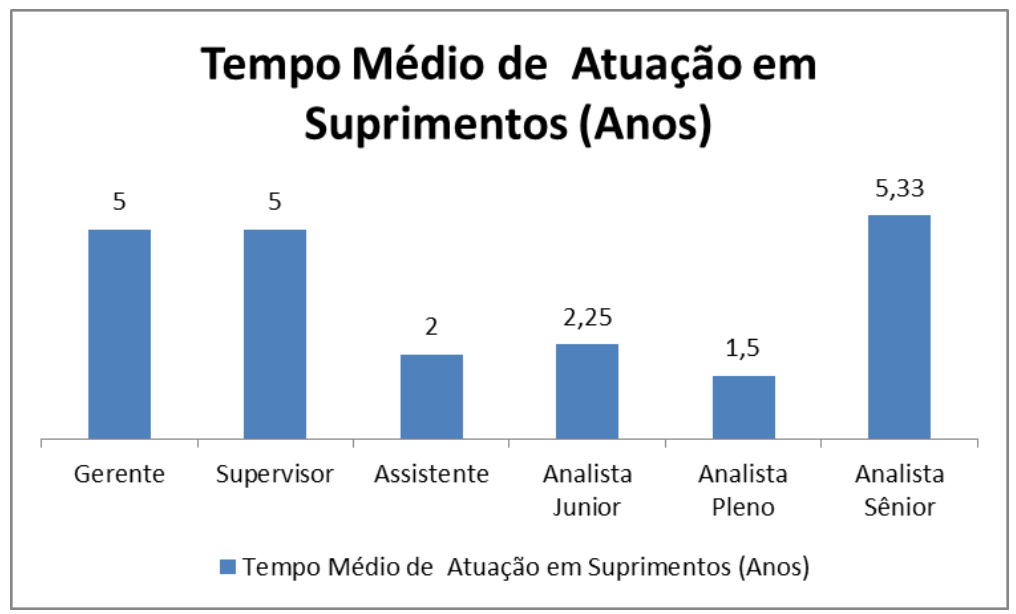

Figura 7- Perfil Profissional dos Integrantes da Categoria de Movimentação Interna Fonte: Autor

O estudo, como será exposto adiante, utilizou-se de um questionário e reuniões presenciais com o grupo focal para a aplicação do modelo de Narasimhan (1983) (Anexo II) para estabelecer o posicionamento dos principais contratos da categoria de Movimentação Interna no modelo de Pagell et al. (2010). O modelo de Narasimhan (1983) foi escolhido, pois tanto no modelo de Pagell et al. (2010) como no modelo proposto por Kraljic(1953), não é descrito qual deve ser o método de atribuição de pesos para os eixos, a fim de posicionar o portfolio de compras na matriz. No entanto, Olsen e Ellram (1997), que possuem um modelo baseado em Kraljic, muito aceito na literatura, usam o método de Narasimhan (1983) para esta atribuição de pesos.

O estudo de caso foi realizado em 3 passos conforme Figura 8 abaixo: 


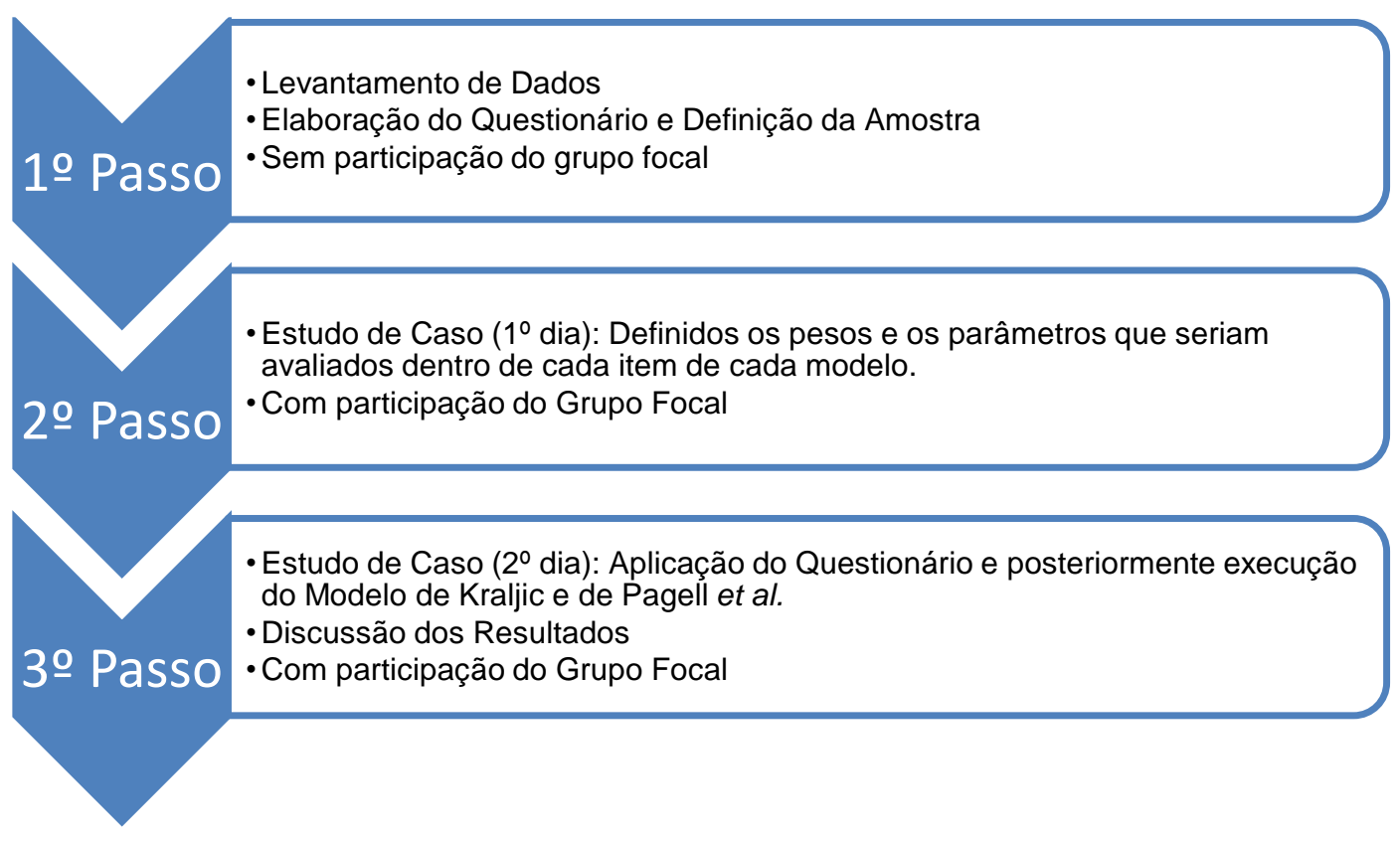

Figura 8- Estudo de Caso Fonte: Autor

$1^{\circ}$ Passo:O levantamento de dados para a aplicação dos modelos de Kraljic (1953) e Pagell et al. (2010) resultou-se da pesquisa de documentos internos da empresa do estudo de caso, tais como relatórios de contratos, informações de consumo dos contratos e, principalmente, da elaboração de um questionário estruturado para registro dos dados necessários à classificação dos itens da amostra selecionada. Além disso, foram usadas referências da literatura para a seleção dos itens que seriam avaliados na aplicação dos modelos. Para a elaboração do questionário, foram estruturadas duas etapas:

- (I) Identificou-se na literatura os parâmetros necessários para a avaliação e aplicação dos modelos escolhidos (Kraljic e Pagell et al.) e determinou-se uma forma de apreciação no que tange a escala e a ponderação dos resultados, seguindo a escala apresentada por Narasimhan (1983), como exposto no Anexo II. Caso o grupo focal não concordasse com a escala de ponderação apresentada, esta poderia ser revista.

- (II) Definiu-se a amostra dos itens que serão avaliados. Em seguida, foi realizada a pesquisa de campo propriamente dita; antes, porém, decidiu-se que todos os funcionários que atuam diretamente nesta categoria responderiam o questionário para registro dos dados e foram escolhidos quais itens deveriam ser avaliados dentro do questionário e das dimensões analisadas pelo autor deste estudo. 
Vale ressaltar que foram selecionados dentre os contratos existentes e vigentes pertencentes a esta categoria, aqueles que juntos representam $80 \%$ do gasto com serviços contratados (spend) anual estimado da categoria. Este percentual foi decidido com base na análise $\mathrm{ABC}$. A categoria de movimentação interna possui em sua carteira, 48 contratos vigentes (base de março 2014). Destes, 12 constituem $80 \%$ do spend anualizado da categoria. Estes 12 contratos formaram a amostra a ser analisada junto aos analistas responsáveis pela gestão desta categoria (grupo focal). Os contratos foram analisados separadamente, mas foi constatado que não havia grande diferenciação entre eles em relação aos tópicos analisados neste estudo.

Para a análise dos dados e aplicação dos modelos, foram necessários 02 dias diferentes de estudo com o grupo focal.

$2^{\circ}$ passo: Estudo de Caso- $1^{\circ}$ dia: Definidos os pesos e os parâmetros que seriam avaliados dentro de cada item de cada modelo. Em relação aos pesos, o grupo focal concordou em seguir os fatores de ponderação propostos por Narasimhan (1983).

Foi apresentado para o Grupo Focal uma lista de Itens para serem avaliados em cada modelo (Kraljic e Pagell et al.) e, foi decidido em conjunto com o grupo, quais seriam analisados e se existia algum que não estivesse exposto mas que era considerado como importante pelo grupo de especialistas.

$3^{\circ}$ passo: Estudo de Caso-2 ${ }^{\circ}$ dia: Aplicação do questionário, conforme modelo exposto no Anexo III, foi aplicado para avaliação dos itens estabelecidos no primeiro dia. Ele era composto por itens de resposta individual e itens para discussão e resposta coletiva. Para cada parâmetro analisado em cada modelo, cada representante do grupo focal deveria dar uma resposta individual com justificativa de acordo com sua percepção. Em relação a aplicação das comparações entre os itens e grau de risco e para a consolidação da justificativa de cada item, a discussão foi com todo o grupo focal. Foi decidido com o grupo focal que caso mais de $80 \%$ da amostra de contratos estudados caísse em um quadrante específico, este seria considerado a subdivisão adequada para o tratamento estratégico dos contratos da categoria de movimentação interna. Caso contrário, mais de uma subdivisão seria analisada. 
Como este método pode ser considerado subjetivo, dado que cada pessoa avalia o item com base em sua experiência própria ,após a conclusão do questionário, as respostas por contrato por item avaliado foram consolidadas e, caso houvesse alguma resposta com discordância significativa das demais ela era levantada para discussão em conjunto entre todos os envolvidos. Caso se chegasse a um consenso em relação as justificativas, estas eram colocadas como representante daquele item. Este consenso era estabelecido quando mais de $80 \%$ dos presentes concordava com uma resposta. Caso contrário, as duas respostas mais votadas seriam avaliadas para se estudar o impacto no resultado final. Em relação ao questionário, as questões individuais discutidas foram com base em cada um dos contratos. Ou seja, cada pessoa respondeu um questionário para cada contrato da amostra. Após esta etapa, não foram observados itens fora do consenso de mais de $80 \%$ do grupo focal. Sendo assim, nas tabelas apresentadas nos dois modelos, o item justificativa faz referência ao consenso do grupo focal.

Em relação ao preenchimento em conjunto das pontuações (item coletivo do questionário), foi seguido o mesmo critério acima. Como no primeiro item foi constatado pelo grupo focal que não havia grande diferenciação entre os contratos da amostra, esse item foi feito apenas com o contrato de maior Spend da categoria.

Após a obtenção das justificativas e das pontuações necessárias, os modelos de Kraljic e de Pagell et al. Foram aplicados e os resultados encontrados discutidos junto com o grupo focal.

Somando-se os dois dias, o tempo total utilizado no estudo foi de aproximadamente 10 horas. 


\section{Contextualização do Estudo de Caso}

Este capítulo apresenta o panorama do setor mineral no Brasil, sua importância para a economia do país e seus principais indicadores. Além disso, também apresenta a relação e importância dos conceitos estudados dentro do setor de mineração brasileiro.

Este setor foi escolhido devido ao importante papel desempenhado pela mineração na economia brasileira e mundial. Esta é uma atividade de longo prazo, que viabiliza crescimento econômico mundial, pois fornece insumo para três principais segmentos que demandam commodities minerais: a construção civil (através da produção de aço e de carvão metalúrgico), a manufatura de bens de consumo (através da produção de cobre e níquel usados em carros, eletrodomésticos, entre outros) e a produção de alimentos (através da produção de fertilizantes).

\subsection{Panorama do Setor de Mineração no Brasil}

De acordo com o relatório apresentado pelo Itaú (2013), a mineração é um dos setores básicos da economia do país, contribuindo de forma decisiva para o bem estar e a melhoria da qualidade de vida das presentes e futuras gerações. Os produtos minerais são essenciais para diversas indústrias como a construção civil, máquinas e equipamentos, automobilística, aeroespacial, naval, material ferroviário, energia, alimentos, petroquímica, química, informática, bens duráveis, entre outras. Ainda de acordo com este documento, O Brasil é um dos países mais ricos do mundo em recursos minerais. O país está entre os 10 países com maior investimento em exploração mineral no mundo. Além disso, o Brasil se destaca mundialmente no setor de mineração. Hoje, é o segundo maior exportador de minério de ferro, manganês e bauxita, e o primeiro em nióbio conforme Figura 9. 


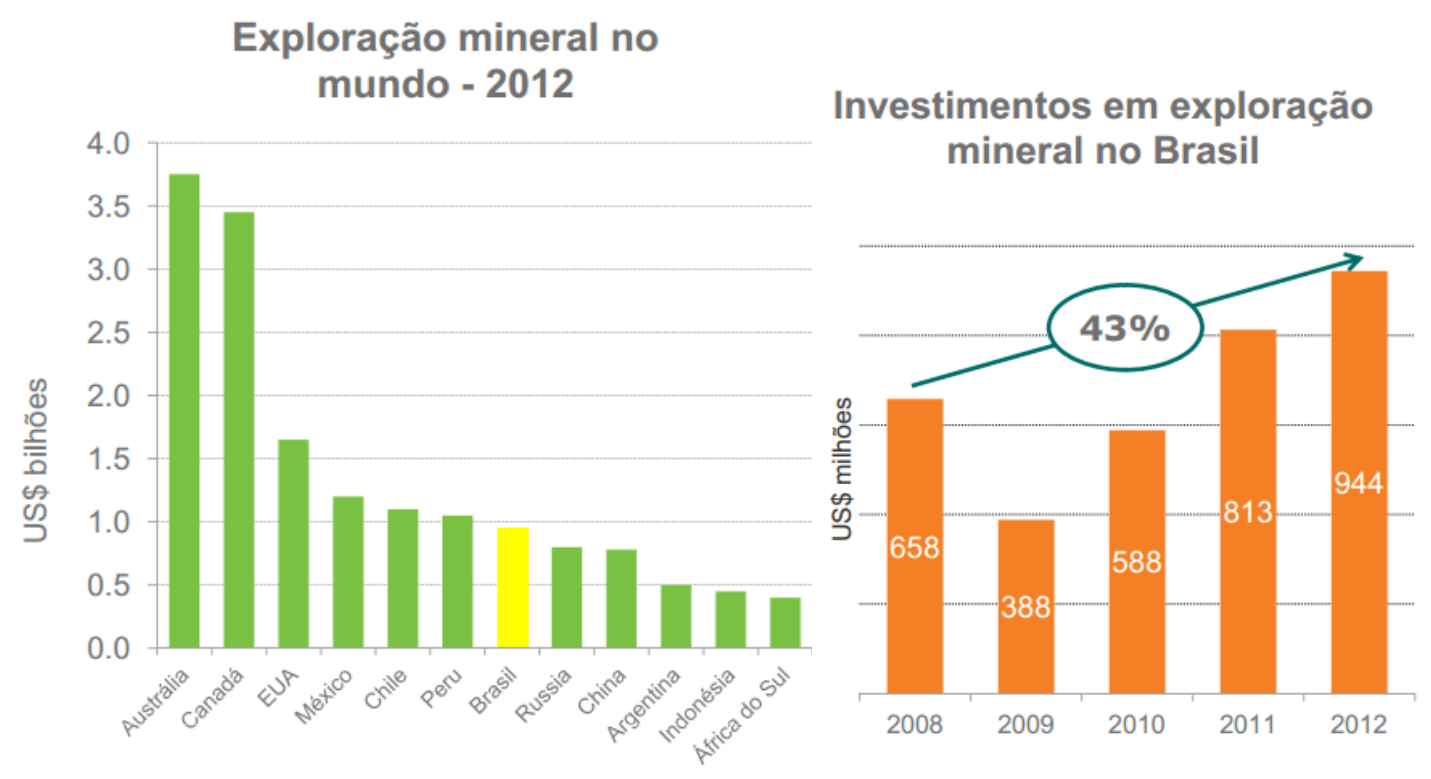

Figura 9- Dados Sobre o Setor de Mineração do Brasil Fonte: Vale (2013)

A mineração é um negócio global e fonte importante de exportações, tendo sido responsável por $15,6 \%$ das vendas externas totais do Brasil no período entre 2008-2012 (Vale, 2013). Segundo o Itaú (2013), o minério de ferro responde por $80 \%$ das exportações brasileiras de minérios. O principal país comprador deste minério é a China (cerca de $50 \%$ do total).

As características estruturais da mineração demandam regulação e tributação adequadas para viabilizar seu potencial de geração de valor para o País. Além disso, é uma atividade que necessita horizonte de planejamento de longo prazo e operações em regiões remotas, o que demanda elevados investimentos em infraestrutura física e social, grandes investimentos em proteção e conservação ambiental. Além disso, está sujeita a diversos riscos como: Geológico, político, operacional, ambiental, regulatório, fiscal, volatilidade de preços e taxa de câmbio, entre outros (Vale, 2013).

Embora em 2012 o setor tenha sofrido uma queda significativa no preço do minério de ferro e consequente queda na extração e exportação, devido à desaceleração da economia chinesa, esta demanda continua alta, mesmo que enfraquecida, o que cria expectativas para a melhora econômica do setor (Itaú, 2013). Além disso, o cenário esperado é que, devido à urbanização das economias emergentes e o consequente crescimento das cidades, haverá uma alavanca de expansão econômica global. É esperado que um bilhão de novos consumidores surjam nos próximos 15 anos (McKinsey Global Institute, 2012). Esses novos 
consumidores demandarão construção de residências, shopping centers e infraestrutura urbana, além de bens de consumo duráveis. Para satisfazer o aumento de demanda serão necessários consideráveis investimentos em mineração (Vale, 2013). Caso este aumento de demanda se confirme, o setor poderá ter grandes crescimentos nos próximos anos.

Devido à natureza desta atividade o risco ao Tripple Bottom Line é muito grande. De acordo com Hilson (2000), o grande desafio para as mineradoras alcançarem o desenvolvimento sustentável requerido pelos múltiplos stakeholders envolvidos nessa atividade é buscar estabelecer metas que os obriguem a elevar os padrões de desenvolvimento social da comunidade envolvida e cumprir um modelo de gestão ambiental, antecipando-se aos problemas da atividade de mineração. Assim, como esta atividade é economicamente, socialmente e ambientalmente impactante, qualquer concepção de mineração sustentável deve incluir a minimização e compensação dos vários impactos negativos que produz, bem como a potencialização dos positivos. Para isso, ela deve manter bons níveis de proteção ecológica e de padrões ambientais, garantir o bem estar socioeconômico, promovendo o crescimento e melhor distribuição da renda, melhoria das condições de educação e saúde, minimização da pobreza através do desenvolvimento local de oportunidades de emprego nas comunidades de entorno.

Nesta linha, de acordo com Silva e Drummond (2005), a maioria das mineradoras de grande porte têm buscado certificações socioambientais, com o objetivo de minimizar os impactos negativos no meio ambiente e aumentar o bemestar da comunidade. Ainda de acordo com os autores, isto é um forte indício de que as empresas compartilham dos novos preceitos da sustentabilidade. Percebese que isso é de fato uma evolução, uma vez que esta atividade sempre esteve invariavelmente ligada à destruição do meio ambiente e alterações na vida da comunidade na qual ela está inserida. 


\subsection{Apresentação da Empresa}

Neste trabalho será estudada uma empresa do setor de mineração brasileiro, aqui denominada como empresa XXX.

Com sede no Rio de Janeiro, a XXX é uma empresa de capital aberto, com presença mundial nos cinco continentes e ações negociadas nas bolsas de São Paulo, Nova York, Hong Kong, Paris e Madri. É a maior produtora mundial de minério de ferro e pelotas e a segunda maior de níquel. Também produz minério de manganês, ferroligas, cobre, metais do grupo platina (PGMs), ouro, prata, cobalto, carvão metalúrgico e térmico, potássio, fosfatados e outros fertilizantes, além de atuar nos setores de logística, siderurgia e energia.

A sustentabilidade é um dos pilares estratégicos da empresa XXX. Esta possui foco em saúde e segurança, otimização de recursos, construção de legado positivo para as comunidades próximas às suas operações e adoção das melhores práticas em gestão socioambiental. No ano de 2013, os recursos aplicados na área socioambiental chegaram a US\$ 1,3 bilhão, com quase $79 \%$ destinados a iniciativas ambientais e $21 \%$, a ações sociais. Ainda em 2013, a empresa procurou incentivar seus fornecedores nos temas sustentabilidade e mudanças climáticas. Uma das ferramentas oferecidas foi a capacitação para que os fornecedores realizem inventários de emissões de gases de efeito estufa. Outra iniciativa é um programa de incentivo ao desenvolvimento dos fornecedores onde a empresa liberou US\$ 415 milhões em financiamentos e créditos com esta finalidade. Além disso, a empresa participa de discussões e iniciativas mundiais que promovam a sustentabilidade. Desde 2011, a empresa é membro do seleto grupo de empresas que fazem parte do Pacto Global Lead das Nações Unidas e também faz parte do Conselho Internacional de Mineração e Metais (ICMM), visando à melhoria contínua da gestão em sustentabilidade.

Nesta empresa, o departamento de compras é divido em compras de serviços e compra de materiais. Este trabalho estudará apenas o departamento de compras de serviços. O setor de compras de serviços é dividido em duas gerências gerais, e cada uma destas em gerências menores. Cada um destes grupos de categoria possui um gerente de área, supervisores e um grupo de compradores especializados nas categorias onde estão alocados. Para este estudo será analisada a categoria de movimentação interna, detalhada a seguir. 


\subsection{Categoria de Movimentação Interna}

A categoria de compras de movimentação interna compreende as compras de serviços das atividades de movimentação e transporte de produtos, insumos, rejeitos, entre outros, como também atividades de recuperação e manutenção de vias e umectação de pilhas e vias de acesso, dentro das instalações de mina, porto, usina ou ferrovia. No ano de 2012, o gasto realizado foi de $\mathrm{R} \$ 714,4 \mathrm{MM}$ dividido em quatro subcategorias conforme abaixo:

- Serviço de Movimentação Interna de Cargas (78,7\% do gasto).

- Serviço de Movimentação Interna com Equipamento Fora de Estrada (12,4\% do gasto).

- Locação de Equipamentos de Movimentação Interna (1,2\% do gasto).

- Locação de Equipamentos Fora de Estrada (7,7\% do gasto).

A principal diferença entre o contrato de serviço e o de locação é a mão de obra que irá operar os equipamentos pertencentes ao escopo. No contrato de serviços, a mão de obra é da empresa Fornecedora e no contrato de locação é da empresa Contratante.

Os fornecedores que atendem a esta categoria não são dedicados somente a ela, já que no mercado não existe um setor específico de movimentação interna. Eles podem pertencer a diversos setores da economia como: transportadores, construtoras, empresas de locação, empresas de logística, terraplanagem, empresas de engenharia e, por isso, o mercado fornecedor é bastante pulverizado.

Nesta categoria, as variáveis chaves usadas na escolha dos fornecedores são: segurança operacional, preço, qualidade, número de reclamações das áreas usuárias em relação a serviços prestados anteriormente pelos fornecedores, política de gestão de resíduos. Um dos maiores problemas enfrentados pelos fornecedores que atendem essa categoria é a falta de mão de obra qualificada. Devido a isto, são necessários salários maiores para reter profissionais qualificados e custos adicionais com treinamento de pessoal, podendo impactar nos custos dos contratos. Em relação aos custos dos contratos de movimentação interna, a maior parte destes é referente aos equipamentos e a mão de obra solicitada no contrato.

A categoria de movimentação interna foi posicionada pela empresa XXX no quadrante alavancagem na matriz de Kraljic, de acordo com um método realizado 
por uma consultoria contratada para ajudar na elaboração do planejamento estratégico da categoria no ano de 2013. Para confirmação do posicionamento da categoria no quadrante de alavancagem, de acordo com o método exposto na literatura, fez-se um estudo de caso descrito no capítulo anterior. 


\section{Estudo de Caso}

Neste tópico será apresentado o estudo de caso realizado para a confirmação da categoria de movimentação interna como pertencente ao quadrante de alavancagem, na matriz de Kraljic (1953) e aplicação do modelo de Pagell et al. (2010), utilizando o modelo de Narasimhan (1983) para posicionamento do portfólio de contratos de Movimentação Interna em ambos os modelos para posteriormente, ser avaliada a estratégia necessária para se obter um processo de compras sustentáveis dentro desta categoria. Este item foi realizado após os passos 1 e 2 expostos no capítulo 3 e compreende os itens apresentados como $3^{\circ}$ passo.

\subsection{Validação da Aplicação do Modelo de Kraljic (1953)}

Atualmente, a categoria de movimentação interna da empresa XXX está posicionada no quadrante alavancagem da matriz de Kraljic. Porém, como este posicionamento foi feito por uma consultoria contratada pela empresa XXX, e o método usado foi adaptado para a realidade da empresa XXX e não de acordo com o encontrado na literatura, foi feita uma nova avaliação da categoria para que ela seja posicionada de acordo com o modelo de Kraljic exposto na literatura.

Para avaliação do eixo de complexidade do mercado fornecedor, foram selecionadas cinco premissas, de acordo com aquelas definidas por Andrade (2012), e a estas foi acrescentada a dependência financeira, considerada importante pelos profissionais entrevistados.

\section{Avaliação do Eixo Horizontal}

Tabela 10- Premissas para Avaliação da Complexidade do Mercado Fornecedor Fonte- Autor

\begin{tabular}{|c|c|l|c|}
\hline Premissas & Questionário & \multicolumn{1}{c|}{ Justificativa - Consenso } & $\begin{array}{c}\text { Impacto na } \\
\text { Complexidade }\end{array}$ \\
\hline $\begin{array}{c}\text { Especialização } \\
\text { do }\end{array}$ & $\begin{array}{c}\text { Tecnologia e } \\
\text { complexidade } \\
\text { envolvidas no } \\
\text { serviço/produto }\end{array}$ & $\begin{array}{l}\text { O serviço contratado na categoria não exige } \\
\text { grande tecnologia/complexidade. Em sua } \\
\text { grande maioria são compostos de } \\
\text { equipamentos de prateleira e mão de obra } \\
\text { pouco especializada. }\end{array}$ & $\begin{array}{c}\text { Quanto maior, } \\
\text { maior a }\end{array}$ \\
\hline complexidade \\
nisponibilidade mercado & $\begin{array}{c}\text { Existe uma alta oferta } \\
\text { no mercado pelo } \\
\text { produto/serviço? }\end{array}$ & $\begin{array}{l}\text { Embora o mercado de fornecedores seja } \\
\text { bastante pulverizado, estes atuam em vários } \\
\text { setores da economia podendo gerar para } \\
\text { alguns processos de contratação baixa } \\
\text { oferta. Porém, estes processos são raros e }\end{array}$ & $\begin{array}{c}\text { Quanto menor, } \\
\text { maior a }\end{array}$ \\
\hline
\end{tabular}




\begin{tabular}{|c|c|c|c|}
\hline & & $\begin{array}{l}\text { muitas vezes os fornecedores declinam não } \\
\text { por indisponibilidade, mas por falta de } \\
\text { interesse no escopo solicitado. Além disso, } \\
\text { devido ao porte e nome da empresa XXX, } \\
\text { muitos fornecedores tem interesse em } \\
\text { participar dos processos concorrenciais que } \\
\text { são convidados. }\end{array}$ & \\
\hline $\begin{array}{l}\text { Custo da } \\
\text { mudança }\end{array}$ & $\begin{array}{l}\text { Quais os custos de } \\
\text { mudança do item por } \\
\text { outro similar ou de } \\
\text { um fornecedor atual } \\
\text { para um novo } \\
\text { fornecedor durante a } \\
\text { vigência do contrato? }\end{array}$ & $\begin{array}{l}\text { Embora existam muitos fornecedores que } \\
\text { possam atender a esta categoria o risco de } \\
\text { trocar um fornecedor é elevado devido à } \\
\text { possibilidade de ocorrência de } \\
\text { descontinuidade na prestação dos serviços. } \\
\text { Isto pode ocorrer principalmente, pois, para } \\
\text { mobilizar um contrato novo, os fornecedores } \\
\text { necessitam de até } 120 \text { dias devido à } \\
\text { aquisição dos equipamentos. Com isso, o } \\
\text { risco do fornecedor que será substituído } \\
\text { abandonar o contrato é grande o o risco de } \\
\text { acontecer uma descontinuidade ou mau } \\
\text { prestação de serviços também. }\end{array}$ & $\begin{array}{l}\text { Quanto maior, } \\
\text { maior a } \\
\text { complexidade. }\end{array}$ \\
\hline $\begin{array}{l}\text { Dependência } \\
\text { Financeira }\end{array}$ & $\begin{array}{l}\text { Qual grau de } \\
\text { dependência que o } \\
\text { fornecedor tem da } \\
\text { empresa? Quanto a } \\
\text { empresa representa } \\
\text { no faturamento do } \\
\text { fornecedor? }\end{array}$ & $\begin{array}{l}\text { Em alguns contratos, a empresa XXX } \\
\text { representa pouco do faturamento dos } \\
\text { fornecedores. Em outros casos, tem-se } \\
\text { fornecedores com quase } 100 \% \text { de } \\
\text { dependência da empresa XXX. A empresa } \\
\text { XXX não tem interesse de ter fornecedores } \\
\text { muito dependentes pois, o risco de qualquer } \\
\text { manobra no contrato necessário pela } \\
\text { empresa XXX, pode quebrar a empresa } \\
\text { fornecedora. }\end{array}$ & $\begin{array}{l}\text { Quanto menor, } \\
\text { maior a } \\
\text { complexidade. }\end{array}$ \\
\hline $\begin{array}{c}\text { Fornecedores } \\
\text { Potenciais }\end{array}$ & $\begin{array}{c}\text { Existem outros } \\
\text { fornecedores em } \\
\text { desenvolvimento para } \\
\text { o fornecimento de } \\
\text { itens já comprados } \\
\text { pela empresa? }\end{array}$ & $\begin{array}{l}\text { A empresa XXX tem um programa de } \\
\text { desenvolvimento de pequenos fornecedores } \\
\text { locais para diminuir o risco de falta de oferta } \\
\text { em suas demandas, principalmente em } \\
\text { locais remotos. }\end{array}$ & $\begin{array}{l}\text { Quanto menor, } \\
\text { maior a } \\
\text { complexidade. }\end{array}$ \\
\hline $\begin{array}{l}\text { Competição na } \\
\text { procura }\end{array}$ & $\begin{array}{c}\text { Os fornecedores são } \\
\text { disputados por muitas } \\
\text { empresas } \\
\text { compradoras? }\end{array}$ & $\begin{array}{l}\text { Como os fornecedores que atendem a } \\
\text { categoria de movimentação interna atendem } \\
\text { diversos outros setores, eles são disputados } \\
\text { entre várias empresas. Porém, devido ao } \\
\text { porte dos contratos normalmente realizados } \\
\text { pela empresa XXX e pelo nome da empresa } \\
\text { contratante ela tem vantagem frente a outras } \\
\text { empresas compradoras. }\end{array}$ & $\begin{array}{l}\text { Quanto maior, } \\
\text { maior a } \\
\text { complexidade. }\end{array}$ \\
\hline
\end{tabular}


Para cada um dos itens mostrados na Tabela 10, foi aplicado o Método de Narasimhan (1983) para avaliação do Eixo Horizontal da Matriz de Kraljic. Não houve discordância na classificação dos contratos para este eixo. Pelos dados apresentados na Tabela 12, pode-se concluir, por exemplo, que o item Especialização do Serviço é um pouco mais importante que o item Dependência Financeira, utilizando os dados da Tabela 11 para comparar cada item com os demais. Após a conclusão da avaliação dos fatores apresentados na Tabela 12, é feita a média geométrica por linha e, posteriormente o somatório de todas as médias dos fatores. Em seguida, é analisado o peso que cada uma das médias representa no total.

Tabela 11- Fatores de Comparação

Fonte: Adaptado de Olsen \& Ellram (1997)

\begin{tabular}{|l|c|}
\hline & Definição \\
\hline 1 & Igualmente importante \\
\hline 3 & Um Pouco Mais importante \\
\hline 5 & Mais importante \\
\hline 7 & Muito Mais importante \\
\hline 9 & Absolutamente importante \\
\hline
\end{tabular}

Tabela 12- Resultado da Aplicação do Método de Narasimhan (1983) para os Itens de Complexidade do Mercado Fornecedor

Fonte: Autor

\begin{tabular}{|c|c|c|c|c|c|c|c|c|c|}
\hline & *1 & *2 & ${ }^{*} 3$ & ${ }^{*} 4$ & ${ }^{*} 5$ & ${ }^{*} 6$ & Multiplicação & Média Geométrica & Peso \\
\hline Especialização do serviço ( $\left.{ }^{*} 1\right)$ & 1,00 & 0,33 & 0,33 & 3,00 & 0,20 & 1,00 & 0,07 & 0,64 & $9 \%$ \\
\hline Disponibilidade no mercado $\left({ }^{*} 2\right)$ & 3,00 & 1,00 & 0,14 & 7,00 & 1,00 & 3,00 & 9,00 & 1,44 & $21 \%$ \\
\hline Custo da mudança $\left({ }^{*} 3\right)$ & 3,00 & 7,00 & 1,00 & 3,00 & 5,00 & 0,33 & 105,00 & 2,17 & $32 \%$ \\
\hline Dependência Financeira $\left({ }^{*} 4\right)$ & 0,33 & 0,14 & 0,33 & 1,00 & 1,00 & 0,33 & 0,005 & 0,42 & $6 \%$ \\
\hline Fornecedores Potenciais $\left({ }^{\star} 5\right)$ & 5,00 & 1,00 & 0,20 & 1,00 & 1,00 & 3,00 & 3,00 & 1,20 & $17 \%$ \\
\hline Competição na procura $\left({ }^{*} 6\right)$ & 1,00 & 0,33 & 3,00 & 3,00 & 0,33 & 1,00 & 1,00 & 1,00 & $15 \%$ \\
\hline & & & & & & & Soma & 6,87 & $100 \%$ \\
\hline
\end{tabular}

Cada fator é então avaliado em importância, para se chegar ao Score final do eixo de Complexidade do mercado fornecedor. Utilizando-se os fatores apresentados na Tabela 13, cada item é avaliado conforme exposto na Tabela 14. $\mathrm{Na}$ Tabela 13, a importância é relativa ao risco. Ou seja, quanto maior a importância, maior o risco considerado.

Por exemplo, a Especialização do Serviço foi avaliada como Importância muito baixa (Risco muito Baixo). O peso é retirado do resultado final mostrado na Tabela 12. Para se chegar ao Score total de cada item, a nota baseada na Tabela 13 é multiplicada ao peso de cada item apresentado na Tabela 12. Após esta etapa ser feita para todos os itens, os Scores encontrados são somados para avaliação do Eixo Horizontal. 
Tabela 13- Escala Determinada na Pesquisa para os Valores de Avaliação dos Itens Fonte: Adaptado de Olsen \& Ellram (1997)

\begin{tabular}{|l|c|}
\hline & Definição \\
\hline 1 & Importância Muito Baixa \\
\hline 3 & Importância Baixa \\
\hline 5 & Importância Moderada \\
\hline 7 & Importância Alta \\
\hline 9 & Importância Muito Alta \\
\hline
\end{tabular}

Tabela 14- Resultado da Ponderação para o Eixo Horizontal da Matriz de Kraljic Utilizando o Método de Narasimhan (1983)

Fonte: Autor

\begin{tabular}{|l|r|r|r|}
\cline { 2 - 4 } \multicolumn{1}{c|}{} & Importância & Peso & Score Total \\
\hline Especialização do serviço $\left({ }^{*} 1\right)$ & 1,00 & $9,3 \%$ & 0,09 \\
\hline Disponibilidade no mercado $\left.{ }^{*}{ }^{*} 2\right)$ & 5,00 & $21,0 \%$ & 1,05 \\
\hline Custo da mudança $\left({ }^{*} 3\right)$ & 7,00 & $31,6 \%$ & 2,21 \\
\hline Dependência Financeira $\left({ }^{*} 4\right)$ & 1,00 & $6,1 \%$ & 0,06 \\
\hline Fornecedores Potenciais $\left({ }^{*} 5\right)$ & 3,00 & $17,5 \%$ & 0,52 \\
\hline Competição na procura $\left({ }^{*} 6\right)$ & 3,00 & $14,6 \%$ & 0,44 \\
\hline & & Soma & 4,38 \\
\hline
\end{tabular}

Para o posicionamento na matriz de Kraljic, foi utilizada escala apresentada na Tabela 13, em relação ao Score Total. Esta escala foi decidida em conjunto com o grupo focal, tendo como base que o score de importância (risco) varia de 1 a 9. Logo, utilizou-se a metade do score de importância como ponto de mudança de quadrante. Ou seja, para este eixo, o risco de fornecimento é baixo. Para este eixo não houve discordância na classificação dos contratos da amostra. 


\section{Avaliaç̃o do Eixo Vertical}

Para avaliação do eixo de Importância das Compras, foram selecionadas

duas premissas de acordo com aquelas definidas por Andrade (2012).

Tabela 15- Premissas para Avaliação do Eixo de Importância das Compras

Fonte: Autor

\begin{tabular}{|c|c|c|c|}
\hline Premissas & Questões & Justificativa - Consenso & $\begin{array}{c}\text { Impacto no } \\
\text { Risco }\end{array}$ \\
\hline $\begin{array}{l}\text { Montante monetário } \\
\text { (efetivo ou } \\
\text { estimado) envolvido } \\
\text { no item; }\end{array}$ & $\begin{array}{llr}\text { Quanto, } & \text { em } \\
\text { dinheiro, o } & \text { item } \\
\text { representa no } & \text { total } \\
\text { comprado } & \text { pela } \\
\text { empresa? } & \\
& & \\
\text {. } & \end{array}$ & $\begin{array}{l}\text { Os contratos da categoria são } \\
\text { intensivos em equipamentos e, por } \\
\text { isso, são contratos normalmente de } \\
\text { alto valor. Além disso, como as } \\
\text { atividades que serão realizadas na } \\
\text { prestação dos serviços são feitas em } \\
\text { sua maioria em condições muito } \\
\text { severas, as máquinas precisam } \\
\text { normalmente ser trocadas antes do } \\
\text { fim da vigência dos contratos (para } \\
\text { contratos com mais de } 03 \text { anos) e } \\
\text { demandam altos custos variáveis } \\
\text { (peças e manutenção, pneus). São } \\
\text { contratos complexos em relação à } \\
\text { execução e as obrigações solicitadas } \\
\text { pela empresa XXX a seus } \\
\text { fornecedores que colocam um peso } \\
\text { financeiro maior devido ao risco que } \\
\text { estão sujeitos seja na quebra precoce } \\
\text { de equipamentos, em multas } \\
\text { aplicadas por falta de funcionamento } \\
\text { dos equipamentos ou acidentes de } \\
\text { seus colaboradores entre outros. }\end{array}$ & $\begin{array}{l}\text { Quanto maior, } \\
\text { maior o risco. }\end{array}$ \\
\hline $\begin{array}{l}\text { Valor agregado pelo } \\
\text { item à cadeia de } \\
\text { suprimentos; o } \\
\text { impacto do item na } \\
\text { qualidade dos } \\
\text { negócios; impacto } \\
\text { do item no } \\
\text { crescimento dos } \\
\text { negócios. }\end{array}$ & $\begin{array}{c}\text { Qual o impacto } \\
\text { financeiro na } \\
\text { empresa, } \\
\text { ocasionado pela } \\
\text { falta do item ou pelo } \\
\text { mesmo estar } \\
\text { disponível fora das } \\
\text { condições ideias? }\end{array}$ & $\begin{array}{l}\text { Caso exista algum tipo de problema } \\
\text { na execução dos contratos que } \\
\text { venham a paralisar as atividades } \\
\text { terceirizadas, podem ocorrer sérios } \\
\text { danos financeiros e a imagem da } \\
\text { empresa XXX. Alguns desses danos } \\
\text { podem ser gerados por atrasos de } \\
\text { carregamento/descarregamento de } \\
\text { trens/navios; poluição severa do ar } \\
\text { decorrente de falta de serviços de } \\
\text { umectação, entre outros. }\end{array}$ & $\begin{array}{l}\text { Quanto maior, } \\
\text { maior o risco. }\end{array}$ \\
\hline
\end{tabular}

Para a avaliação de cada item, foi feita a mesma análise do eixo horizontal, utilizando o método de Narasimhan (1983). Como resultado da aplicação do 
método mostrado nas Tabelas 16 e 17, para o eixo de Importância de Compras, o risco é considerado alto. Para este eixo não houve discordância na classificação dos contratos da amostra.

Tabela 16- Resultado da Aplicação do Método de Narasimhan (1983) para os Itens de Importância das Compras Fonte: Autor

\begin{tabular}{|l|r|r|r|r|r|}
\hline & \multicolumn{1}{|c|}{${ }^{*} 1$} & \multicolumn{1}{|c|}{${ }^{*} 2$} & Multiplicação & Média Geométrica & Peso \\
\hline Montante monetário $\left({ }^{*} 1\right)$ & 1,00 & 0,33 & 0,33 & 0,58 & $25 \%$ \\
\hline Valor agregado pelo item à cadeia de suprimento & 3,00 & 1,00 & 3,00 & 1,73 & $75 \%$ \\
\hline & & & Soma & 2,31 & $100 \%$ \\
\hline
\end{tabular}

Tabela 17- Resultado da Ponderação para o Eixo Vertical da Matriz de Kraljic Utilizando o Método de Narasimhan (1983)

Fonte: Autor

\begin{tabular}{|l|r|r|r|}
\cline { 2 - 3 } \multicolumn{1}{c|}{} & Importância & Peso & Score Total \\
\hline Montante monetário $\left.{ }^{*}{ }^{*} 1\right)$ & 7,00 & $25 \%$ & 1,75 \\
\hline Valor agregado pelo item à cadeia de suprimentos $\left.{ }^{*}{ }^{*} 2\right)$ & 9,00 & $75 \%$ & 6,75 \\
\hline & & Soma & 8,50 \\
\hline
\end{tabular}

Sendo assim, após a reavaliação do posicionamento da categoria de Movimentação Interna utilizando a análise da amostra de contratos selecionada, ficou constatado que a mesma se encontra no quadrante de Alavancagem da Matriz de Kraljic conforme exposto na Tabela 18.

Tabela 18- Score para Classificação dos Itens Fonte: Autor

\begin{tabular}{|c|c|c|c|}
\cline { 3 - 3 } \multicolumn{2}{c|}{} & \multicolumn{2}{c|}{ Complexidade Mercado Fornecedor } \\
\cline { 3 - 4 } \multicolumn{2}{c|}{} & $<\mathbf{4 , 5}$ & $>\mathbf{4 , 5}$ \\
\hline \multirow{2}{*}{$\begin{array}{c}\text { Importância das } \\
\text { Compras }\end{array}$} & $<\mathbf{4 , 5}$ & Não Crítico & Gargalo \\
\cline { 2 - 4 } & $>\mathbf{4 , 5}$ & Alavancagem & Estratégico \\
\hline
\end{tabular}

\subsection{Modelo de Pagell et al. (2010)}

Para aplicação do modelo de Pagell et al. (2010), é necessário avaliar os 02 eixos que o compõe. O primeiro faz referência ao Tripple Bottom Line da Sustentabilidade e o segundo faz referência ao Risco de Suprimentos.

Partindo do estudo realizado e exposto na seção 4.1, a categoria de movimentação interna se encontra alocada no quadrante de alavancagem da Matriz de Kraljic. Sendo assim, como no modelo proposto por Pagell et al. (2010) este quadrante se divide em três, foi aplicado um questionário, seguido da aplicação do método de Narasimhan (1983) (Anexo II) para posicionamento 
correto dos contratos escolhidos como amostragem da categoria de movimentação interna.

Para o eixo de avaliação do Tripple Bottom Line, foram consideradas as seguintes variáveis, conforme a Tabela 19 abaixo. Em relação as pontuações escolhidas, as mesmas foram baseadas no modelo de Narasimhan (1983) e aceitas pelo grupo focal que participou deste estudo de caso. Para a escolha dos itens que seriam estudados em cada esfera do Tripple Bottom Line foram apresentados os itens encontrados na literatura, os mesmos foram discutidos e acordados com o grupo focal baseado na realidade da empresa XXX. Para algumas dimensões, o grupo focal solicitou a inclusão de itens condizentes com a realidade da empresa XXX.

\section{Avaliacão do Eixo Vertical}

Tabela 19- Componentes do Tripple Bottom Line Utilizados no Estudo de Caso Fonte: Autor

\begin{tabular}{|c|c|c|c|}
\hline \multicolumn{3}{|c|}{ Fonte: Autor } & \multirow{2}{*}{$\begin{array}{c}\text { Referência } \\
\text { Montibeller-Filho (2001) }\end{array}$} \\
\hline \multirow{8}{*}{ 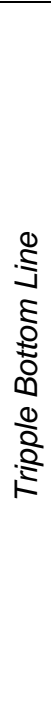 } & \multirow{3}{*}{ Impacto Ambiental } & Uso de recursos não renováveis & \\
\hline & & Geração de Resíduos & Montibeller-Filho (2001) \\
\hline & & $\begin{array}{l}\text { Necessidade de Cuidados } \\
\text { Ambientais }\end{array}$ & Montibeller-Filho (2001) \\
\hline & \multirow{3}{*}{ Impacto Social } & $\begin{array}{l}\text { Desenvolvimento da Comunidade } \\
\text { Local }\end{array}$ & Montibeller-Filho (2001) \\
\hline & & $\begin{array}{l}\text { Desenvolvimento de Pequenos } \\
\text { Fornecedores }\end{array}$ & Grupo Focal \\
\hline & & $\begin{array}{l}\text { Saúde e Segurança dos } \\
\text { Colaboradores }\end{array}$ & Grupo Focal \\
\hline & \multirow{2}{*}{ Impacto Econômico } & Montante Monetário Envolvido & Andrade (2012) \\
\hline & & $\begin{array}{l}\text { Valor Agregado Pelo Item a } \\
\text { Cadeia de Negócios }\end{array}$ & Andrade (2012) \\
\hline
\end{tabular}

Após, para cada dimensão do triple bottom line, foi aplicado com o apoio de um questionário o método de Narasimhan (1983), para que as dimensões fossem avaliadas com o objetivo de estudar se a categoria está sujeita a ter mais de uma dimensão do Triple Bottom Line com alto risco, que é uma das variáveis de posicionamento no modelo de Pagell et al. (2010). 


\section{Dimensão Ambiental}

\begin{tabular}{|c|c|c|c|}
\hline Premissas & Questões & Justificativa - Consenso & Impacto \\
\hline 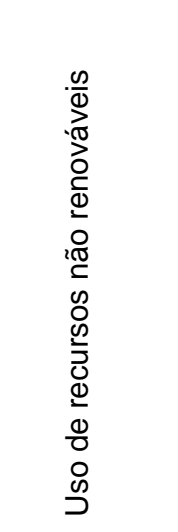 & $\begin{array}{l}\text { Qual a necessidade de } \\
\text { recursos para a } \\
\text { realização dos } \\
\text { serviços? } \\
\text { Existe algum programa } \\
\text { de controle ou redução } \\
\text { do consumo dos } \\
\text { mesmos? }\end{array}$ & $\begin{array}{l}\text { Os contratos da categoria possuem muitas } \\
\text { máquinas e as mesmas necessitam de } \\
\text { combustíveis fósseis em grande escala para } \\
\text { funcionamento. } \\
\text { Não existe programa de controle, porém, a } \\
\text { empresa Contratante exige de seus } \\
\text { fornecedores manutenção periódica nos } \\
\text { equipamentos o que pode contribuir para a } \\
\text { diminuição do consumo de combustível. }\end{array}$ & $\begin{array}{l}\text { Caso o uso } \\
\text { seja alto, o } \\
\text { impacto } \\
\text { ambiental } \\
\text { também será } \\
\text { alto. }\end{array}$ \\
\hline 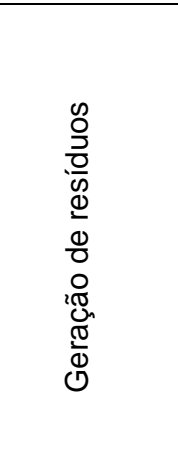 & $\begin{array}{l}\text { Os contratos que } \\
\text { atendem a categoria } \\
\text { de Movimentação } \\
\text { Interna geram grande } \\
\text { quantidade de } \\
\text { resíduos? }\end{array}$ & $\begin{array}{l}\text { A maioria dos resíduos gerados nestes } \\
\text { contratos são gases provenientes da operação } \\
\text { das máquinas e resíduos gerados pela } \\
\text { manutenção periódica dos equipamentos. A } \\
\text { contratante exige nos contratos que os } \\
\text { fornecedores possuam programas de controle } \\
\text { de geração de gases e que tenham um } \\
\text { programa de despejo adequado de resíduos } \\
\text { provenientes da manutenção das máquinas }\end{array}$ & $\begin{array}{l}\text { Caso a } \\
\text { geração seja } \\
\text { alta, o impacto } \\
\text { ambiental } \\
\text { também será } \\
\text { alto. }\end{array}$ \\
\hline 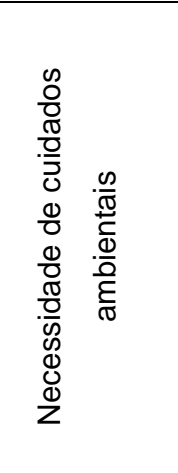 & $\begin{array}{l}\text { Quais os riscos } \\
\text { ambientais que podem } \\
\text { ser ocasionados por } \\
\text { problemas na } \\
\text { execução das } \\
\text { atividades contratadas? }\end{array}$ & $\begin{array}{l}\text { Os serviços prestados nesta categoria podem } \\
\text { impactar negativamente o meio ambiente. } \\
\text { Como exemplo, pode-se citar o caso dos } \\
\text { serviços de aspersão, que fazem parte da } \\
\text { categoria e que se forem paralisados por } \\
\text { algum problema, pode ocasionar a subida da } \\
\text { poeira de minério, que causará danos sérios à } \\
\text { saúde das pessoas nas proximidades, além da } \\
\text { contaminação do ar. }\end{array}$ & $\begin{array}{l}\text { Caso a } \\
\text { necessidade } \\
\text { de cuidados } \\
\text { seja alta, o } \\
\text { impacto } \\
\text { ambiental } \\
\text { também será } \\
\text { alto }\end{array}$ \\
\hline
\end{tabular}

Para aplicação do método de Narasimhan (1983), foram usadas as escalas mostradas nas Tabelas 21 e 23, para comparação dos itens que compõem o pilar ambiental. Todos os contratos da amostra foram avaliados e somente 01 apresentou divergência no que diz respeito ao item de "Necessidades de Cuidados Ambientais" em relação aos demais contratos analisados. 
Tabela 21- Escala de Avaliação

Fonte: Adaptado de Olsen \& Ellram (1997)

\begin{tabular}{|l|c|}
\hline & Definição \\
\hline 1 & Igualmente importante \\
\hline 3 & Um Pouco Mais importante \\
\hline 5 & Mais importante \\
\hline 7 & Muito Mais importante \\
\hline 9 & Absolutamente importante \\
\hline
\end{tabular}

A Tabela 22 apresenta a primeira etapa do Método de Narasimhan (1983), onde os itens são comparados entre si de acordo com a importância de cada um.

Tabela 22- Resultado da Aplicação do Método de Narasimhan (1983) para os Itens que Compõem o Pilar de Impacto Ambiental

Fonte: Autor

\begin{tabular}{|l|r|r|r|r|r|r|}
\hline & ${ }^{*} 1$ & ${ }^{*} 2$ & ${ }^{*} 3$ & Multiplicação & Média Geométrica & Peso \\
\hline Uso de recursos não renováveis $\left.{ }^{*} 1\right)$ & 1,00 & 1,00 & 0,33 & 0,33 & 0,69 & $20 \%$ \\
\hline Geração de resíduos ${ }^{*}{ }^{*}$ ) & 1,00 & 1,00 & 0,33 & 0,33 & 0,69 & $20 \%$ \\
\hline Necessidade de cuidados ambientais ( $\left.{ }^{*} 3\right)$ & 3,00 & 3,00 & 1,00 & 9,00 & 2,08 & $60 \%$ \\
\hline & & & & Soma & 3,47 & $100 \%$ \\
\hline
\end{tabular}

Tabela 23- Escala Determinada na Pesquisa para os Valores de Avaliação dos Itens Fonte: Adaptado de Olsen \& Ellram (1997)

\begin{tabular}{|l|c|}
\hline & Definição \\
\hline 1 & Importância Muito Baixa \\
\hline 3 & Importância Baixa \\
\hline 5 & Importância Moderada \\
\hline 7 & Importância Alta \\
\hline 9 & Importância Muito Alta \\
\hline
\end{tabular}

A Tabela 24 apresenta o resultado da ponderação do Método de Narasimhan (1983). A escala da Tabela 23 está sendo mensurada pelo grau de risco ao invés do grau de importância. Dessa forma, pode-se chegar a conclusão que para a dimensão ambiental, o risco é alto.

Tabela 24- Resultado da Ponderação Total para Avaliação do Impacto Ambiental Fonte: Autor

\begin{tabular}{|l|c|c|c|}
\cline { 2 - 4 } \multicolumn{1}{c|}{} & Importância & Peso & Score Total \\
\hline Uso de recursos não renováveis $\left({ }^{*} 1\right)$ & 5 & $20 \%$ & 1 \\
\hline Geração de resíduos $\left({ }^{*} 2\right)$ & 5 & $20 \%$ & 1 \\
\hline Necessidade de cuidados ambientais $\left({ }^{*} 3\right)$ & 9 & $60 \%$ & 5,4 \\
\hline & & Soma & 7,4 \\
\hline
\end{tabular}




\section{Dimensão Social}

Tabela 25- Análise da Dimensão Social

Fonte: Autor

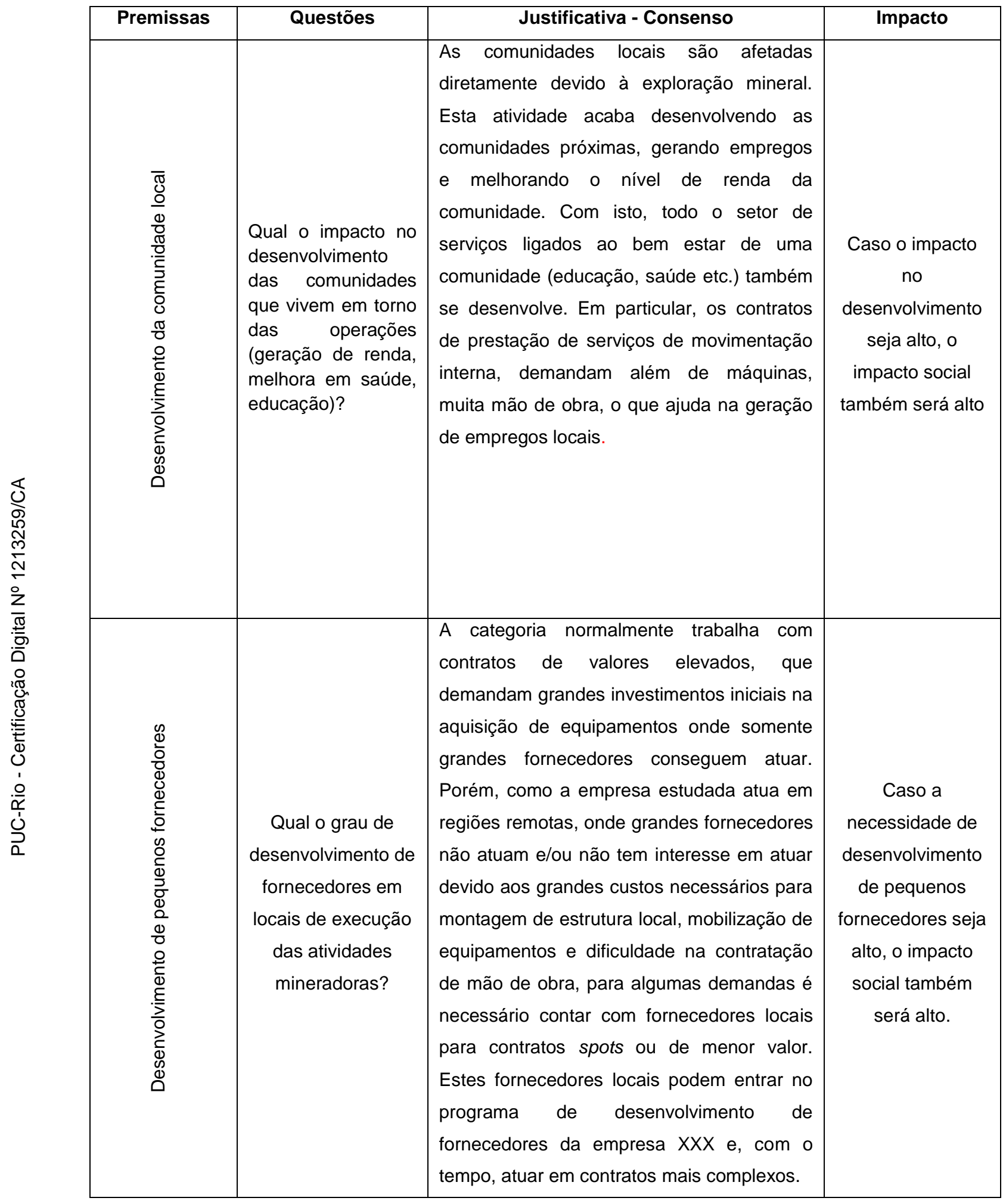




\begin{tabular}{|c|c|c|c|}
\hline 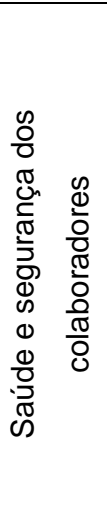 & $\begin{array}{c}\text { Qual a } \\
\text { importância } \\
\text { necessária aos } \\
\text { itens de saúde e } \\
\text { segurança? }\end{array}$ & $\begin{array}{l}\text { Em todos os contratos desta categoria, o } \\
\text { fornecedor é cobrado pela integridade física } \\
\text { dos seus colaboradores. Treinamentos de } \\
\text { segurança para início da prestação de } \\
\text { atividades são realizados e os colaboradores } \\
\text { só devem executar atividades onde se } \\
\text { sintam seguros. Além disso, o fornecedor } \\
\text { pode ser penalizado caso seus funcionários } \\
\text { sofram algum tipo de acidente durante a } \\
\text { prestação dos serviços. }\end{array}$ & $\begin{array}{c}\text { Caso o grau de } \\
\text { importância seja } \\
\text { alto, o impacto } \\
\text { social também } \\
\text { será alto }\end{array}$ \\
\hline
\end{tabular}

Para aplicação do método de Narasimhan (1983), foram usadas as escalas mostradas nas Tabelas 21 e 23, para comparação dos itens que compõem o pilar social. Todos os contratos da amostra foram avaliados e todos apresentaram o mesmo resultado de avaliação. A Tabela 26 apresenta a primeira etapa do Método de Narasimhan (1983) onde os itens são comparados entre si de acordo com a importância de cada um.

Tabela 26- Resultado da Aplicação do Método de Narasimhan (1983) para os Itens que Compõem o Pilar de Impacto Social.

Fonte: Autor

\begin{tabular}{|l|r|r|r|r|r|r|}
\hline & \multicolumn{1}{|c|}{${ }^{*} 1$} & \multicolumn{1}{c|}{${ }^{*} 2$} & \multicolumn{1}{c|}{${ }^{*} 3$} & Multiplicação & Média Geométrica & Peso \\
\hline Desenvolvimento da comunidade local $\left.{ }^{*} 1\right)$ & 1,00 & 3,00 & 0,33 & 1,00 & 1,00 & $26 \%$ \\
\hline Desenvolvimento de pequenos fornecedores ${ }^{*}$ *2) & 0,33 & 1,00 & 0,20 & 0,07 & 0,41 & $10 \%$ \\
\hline Saúde e segurança dos colaboradores $\left({ }^{*} 3\right)$ & 3,00 & 5,00 & 1,00 & 15,00 & 2,47 & $64 \%$ \\
\hline & & & & Soma & 3,87 & $100 \%$ \\
\hline
\end{tabular}

A Tabela 27, apresenta o resultado da ponderação do Método de Narasimhan (1983). A escala da Tabela 23 está sendo mensurada pelo grau de risco ao invés do grau de importância. Dessa forma, pode-se chegar a conclusão que para a dimensão social, o risco é alto.

Tabela 27- Resultado da Ponderação Total para Avaliação do Impacto Social Fonte: Autor

\begin{tabular}{|l|r|r|r|}
\cline { 2 - 4 } \multicolumn{1}{c|}{} & Importância & Peso & Score Total \\
\hline Desenvolvimento da comunidade local $\left({ }^{*} 1\right)$ & 5 & $26 \%$ & 1,3 \\
\hline Desenvolvimento de pequenos fornecedores $\left({ }^{*} 2\right)$ & 3 & $10 \%$ & 0,3 \\
\hline Saúde e segurança dos colaboradores $\left({ }^{*} 3\right)$ & 9 & $64 \%$ & 5,7 \\
\hline & & Soma & 7,3 \\
\hline
\end{tabular}




\section{Dimensão Econômica}

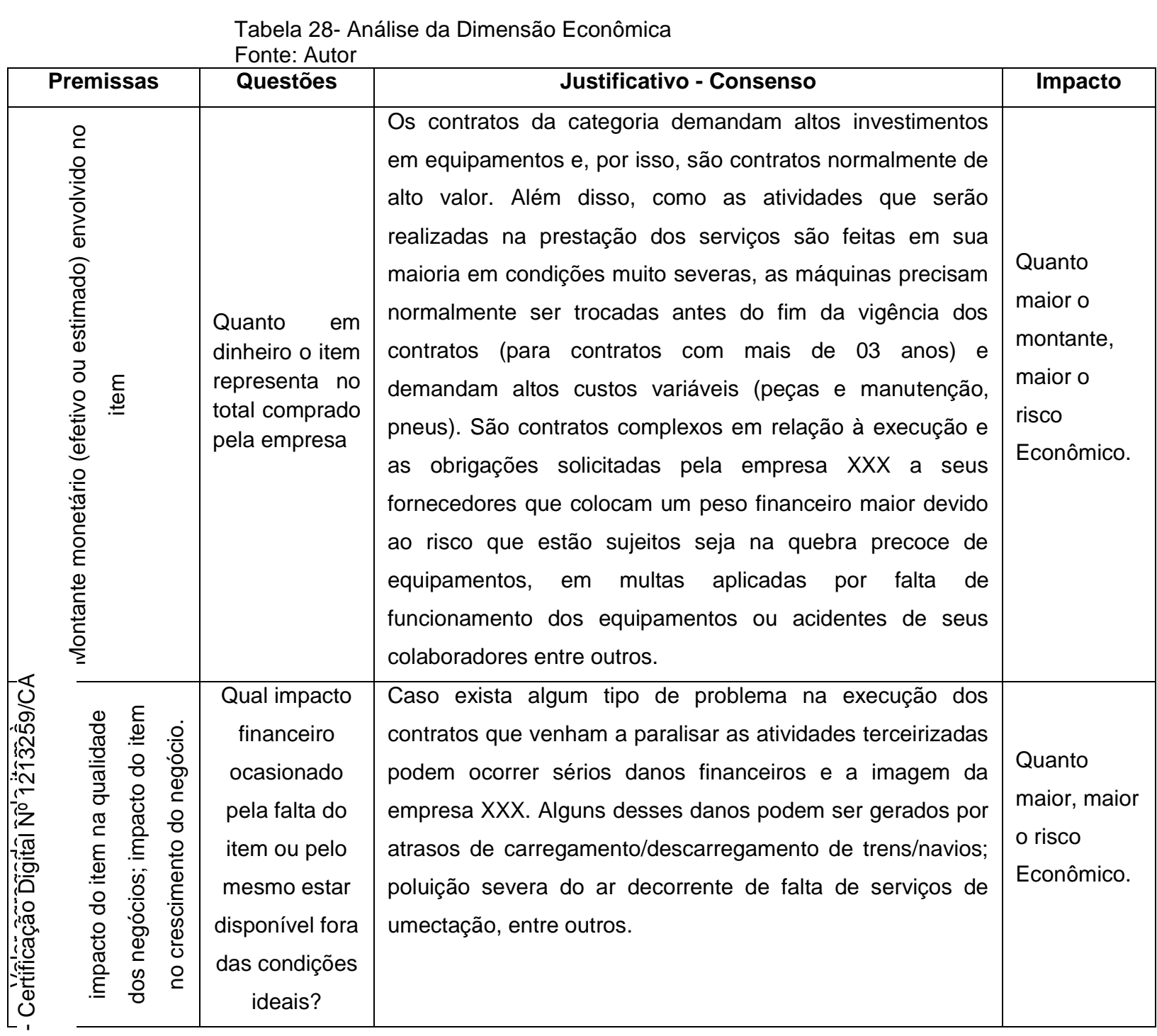

Para aplicação do método de Narasimhan (1983), foram usadas as escalas mostradas nas Tabelas 21 e 23, para comparação dos itens que compõem o pilar social. Todos os contratos da amostra foram avaliados e todos apresentaram o mesmo resultado de avaliação. A Tabela 29 apresenta a primeira etapa do Método de Narasimhan (1983) onde os itens são comparados entre si de acordo com a importância de cada um.

Tabela 29- Resultado da Aplicação do Método de Narasimhan (1983) para os Itens que Compõem o Pilar de Impacto Econômico

Fonte: Autor

\begin{tabular}{|l|r|r|r|r|r|}
\hline & \multicolumn{1}{|c|}{${ }^{*} 1$} & \multicolumn{1}{c|}{${ }^{\star} 2$} & Multiplicação & Média Geométrica & Peso \\
\hline Montante monetário ( $\left.{ }^{*} 1\right)$ & 1,00 & 0,33 & 0,33 & 0,58 & $25 \%$ \\
\hline Valor agregado pelo item à cadeia de suprimentos ${ }^{*}$ 2) & 3,00 & 1,00 & 3,00 & 1,73 & $75 \%$ \\
\hline & & & Soma & 2,31 & $100 \%$ \\
\hline
\end{tabular}


A Tabela 30, apresenta o resultado da ponderação do Método de Narasimhan (1983). A escala da Tabela 23 está sendo mensurada pelo grau de risco ao invés do grau de importância. Dessa forma, pode-se chegar a conclusão que para a dimensão social, o risco é alto.

Tabela 30- Resultado da Ponderação Total para Avaliação do Impacto Econômico Fonte: Autor

\begin{tabular}{|l|r|r|r|}
\cline { 2 - 4 } \multicolumn{1}{c|}{} & Importância & Peso & Score Total \\
\hline Montante monetário $\left({ }^{*} 1\right)$ & 7,00 & $25 \%$ & 1,75 \\
\hline Valor agregado pelo item à cadeia de suprimentos $\left({ }^{*} 2\right)$ & 9,00 & $75 \%$ & 6,75 \\
\hline \multicolumn{1}{|c|}{} & & Soma & 8,50 \\
\hline
\end{tabular}

Após aplicação do Método de Narasimhan (1983), em relação a cada um dos pilares do Tripple Bottom Line, chegou-se ao resultado apresentado na Tabela 31.

Tabela 31- Resultado do Score Apontado pelo Método de Narasimhan (1983) Fonte: Autor

\begin{tabular}{|l|l|l|}
\hline \multicolumn{1}{|c|}{ Pilar } & \multicolumn{1}{|c|}{ Score } & \multicolumn{1}{c|}{ Avaliação Risco } \\
\hline Ambiental & 7,4 & Alto \\
\hline Social & 7,3 & Alto \\
\hline Econômico & 8,5 & Alto \\
\hline
\end{tabular}

\section{Avaliação do Eixo Horizontal}

Para confirmar o posicionamento dentro do modelo de Pagell et al. (2010), foi analisado também o eixo horizontal. Para esta análise, foi realizado o mesmo método do eixo anterior. Neste eixo, não houve discordância na alocação dos contratos estudados.

Para o eixo de avaliação do Risco de Fornecimento, foram consideradas as mesmas variáveis do modelo de Kraljic (1953) mais as seguintes variáveis, definidas em conjunto com o grupo focal conforme Figura 10 baseadas nas práticas de continuidade apresentadas no modelo de Pagell et al. (2010). Em relação aos scores escolhidos, os mesmos foram baseados nas premissas mostradas na avaliação do eixo vertical. 


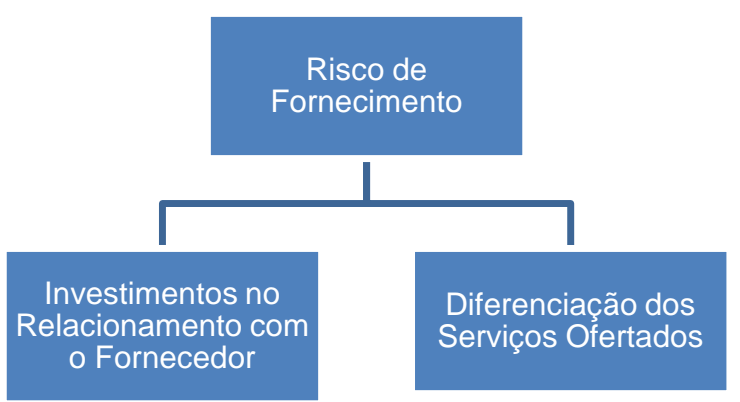

Figura 10- Componentes Adicionados a Análise de Risco de Fornecimento Utilizados no Estudo de Caso

Fonte: Autor

Tabela 32- Premissas Acrescentadas para Avaliação do Risco de Fornecimento Fonte: Autor

\begin{tabular}{|c|c|c|c|}
\hline Premissas & Questões & Justificativa- Consenso & $\begin{array}{c}\text { Impacto na } \\
\text { Complexidade }\end{array}$ \\
\hline 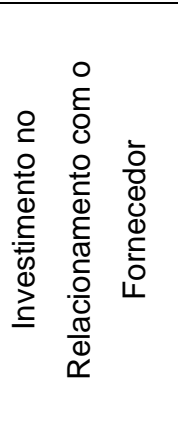 & $\begin{array}{c}\text { Quanto tempo, } \\
\text { dinheiro e } \\
\text { recursos são } \\
\text { gastos para } \\
\text { manter um } \\
\text { relacionamento } \\
\text { de parceria com } \\
\text { o fornecedor? }\end{array}$ & $\begin{array}{l}\text { A empresa XXX procura investir em } \\
\text { relacionamentos de longo prazo com seus } \\
\text { fornecedores seja desenvolvendo-os ou realizando } \\
\text { Workshops com temas relacionados a saúde e } \\
\text { segurança, sustentabilidade, entre outros. A } \\
\text { empresa está sempre buscando uma relação de } \\
\text { parceria com seus fornecedores. }\end{array}$ & $\begin{array}{l}\text { Caso a } \\
\text { necessidade de } \\
\text { investimento } \\
\text { seja alto, o risco } \\
\text { também será } \\
\text { alto. }\end{array}$ \\
\hline 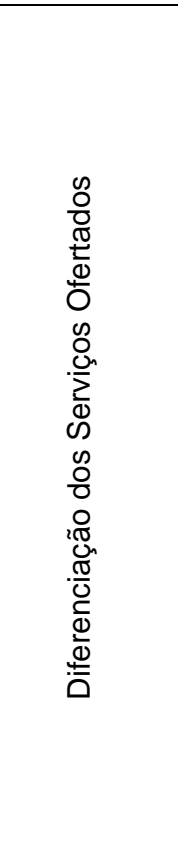 & $\begin{array}{c}\text { Existe } \\
\text { necessidade de } \\
\text { customização } \\
\text { ou a maior parte } \\
\text { dos serviços são } \\
\text { padronizados? } \\
\text { Qual a } \\
\text { frequência que } \\
\text { soluções } \\
\text { alternativas são } \\
\text { oferecidas? }\end{array}$ & $\begin{array}{l}\text { A maior parte dos serviços prestados não apresenta } \\
\text { grande diferenciação pois os equipamentos e a } \\
\text { forma de se prestar o serviço já são enviadas na } \\
\text { especificação técnica. Porém, em alguns tipos de } \\
\text { contratações, a expertise do fornecedor é solicitada } \\
\text { e fica a critério do mesmo nos enviar como seria a } \\
\text { prestação dos serviços, quais máquinas utilizaria e } \\
\text { em que quantidades. Porém, esta forma de } \\
\text { contratação não ocorre com muita frequência. } \\
\text { Normalmente, a área cliente envia uma demanda já } \\
\text { definida para que suprimentos cote com o mercado. } \\
\text { Às vezes um fornecedor também pode aparecer } \\
\text { com uma solução alternativa, que é encaminhada } \\
\text { para avaliação e validação da área cliente. Este } \\
\text { ponto é considerado importante dentro da categoria } \\
\text { mas não é muito observado em processos. }\end{array}$ & $\begin{array}{l}\text { Caso exista } \\
\text { grande } \\
\text { diferenciação, o } \\
\text { risco será alto }\end{array}$ \\
\hline
\end{tabular}

Em seguida, foi aplicado o método de Narasimhan (1983) (anexo II), para avaliação de cada item que compõe o eixo de Risco de Fornecimento baseado nas mesmas escalas utilizadas na avaliação do eixo vertical. Todos os contratos da 
amostra foram avaliados e todos apresentaram o mesmo resultado de avaliação. A

Tabela 33 apresenta a primeira etapa do Método de Narasimhan (1983) onde os itens são comparados entre si de acordo com a importância de cada um.

Tabela 33- Resultado da Aplicação do Método de Narasimhan (1983) para os Itens que Compõem o Eixo de Risco de Fornecimento

Fonte: Autor

\begin{tabular}{|c|c|c|c|c|c|c|c|c|c|c|c|}
\hline & *1 & *2 & *3 & *4 & *5 & ${ }^{*} 6$ & ${ }^{\star} 7$ & ${ }^{*} 8$ & Multiplicação & Média Geométrica & Peso \\
\hline Especialização do serviço $\left.{ }^{*}{ }^{*} 1\right)$ & 1,00 & 0,33 & 0,33 & 3,00 & 0,20 & 1,00 & 0,20 & 1,00 & 0,01 & 0,58 & $6 \%$ \\
\hline Disponibilidade no mercado ( $\left.{ }^{\star} 2\right)$ & 3,00 & 1,00 & 0,14 & 7,00 & 1,00 & 3,00 & 0,20 & 3,00 & 5,40 & 1,23 & $13 \%$ \\
\hline Custo da mudança $\left({ }^{\star} 3\right)$ & 3,00 & 7,00 & 1,00 & 3,00 & 5,00 & 0,33 & 5,00 & 3,00 & 1575,00 & 2,51 & $27 \%$ \\
\hline Dependência Financeira $\left({ }^{*} 4\right)$ & 0,33 & 0,14 & 0,33 & 1,00 & 1,00 & 0,33 & 0,20 & 0,33 & 0,000 & 0,37 & $4 \%$ \\
\hline Fornecedores Potenciais $\left({ }^{*} 5\right)$ & 5,00 & 1,00 & 0,20 & 1,00 & 1,00 & 3,00 & 5,00 & 5,00 & 75,00 & 1,72 & $18 \%$ \\
\hline Competição na procura $\left({ }^{*} 6\right)$ & 1,00 & 0,33 & 3,00 & 3,00 & 0,33 & 1,00 & 1,00 & 1,00 & 1,00 & 1,00 & $11 \%$ \\
\hline Investimento no Relacionamento com o fornecedor ( $\left.{ }^{*} 7\right)$ & 5,00 & 5,00 & 0,20 & 5,00 & 0,20 & 1,00 & 1,00 & 1,00 & 5,00 & 1,22 & $13 \%$ \\
\hline \multirow[t]{2}{*}{ Diferenciação dos Serviços Ofertados ( $\left.{ }^{*} 8\right)$} & 1,00 & 0,33 & 0,33 & 3,00 & 0,20 & 1,00 & 1,00 & 1,00 & 0,07 & 0,71 & $8 \%$ \\
\hline & & & & & & & & & Soma & 9,35 & $100 \%$ \\
\hline
\end{tabular}

A Tabela 34, apresenta o resultado da ponderação do Método de Narasimhan (1983). Dessa forma, pode-se chegar a conclusão que para o eixo de Risco de Fornecimento, o risco é alto.

Tabela 34- Resultado da Ponderação Total para Avaliação do Eixo de Risco de Fornecimento

Fonte: Autor

\begin{tabular}{|l|r|r|r|}
\cline { 2 - 4 } \multicolumn{1}{c|}{} & Importância & Peso & \multicolumn{1}{l|}{ Score Total } \\
\hline Especialização do serviço $\left({ }^{*} 1\right)$ & 1,00 & $6,2 \%$ & 0,06 \\
\hline Disponibilidade no mercado $\left({ }^{*} 2\right)$ & 5,00 & $13,2 \%$ & 0,66 \\
\hline Custo da mudança $\left.{ }^{*} 3\right)$ & 7,00 & $26,8 \%$ & 1,88 \\
\hline Dependência Financeira $\left({ }^{*} 4\right)$ & 1,00 & $4,0 \%$ & 0,04 \\
\hline Fornecedores Potenciais $\left({ }^{*} 5\right)$ & 3,00 & $18,3 \%$ & 0,55 \\
\hline Competição na procura $\left({ }^{*} 6\right)$ & 3,00 & $10,7 \%$ & 0,32 \\
\hline Investimento no Relacionamento com o fornecedor $\left({ }^{*} 7\right)$ & 5,00 & $13,1 \%$ & 0,65 \\
\hline Diferenciação dos Serviços Ofertados $\left.{ }^{*} 8\right)$ & 3,00 & $7,6 \%$ & 0,23 \\
\hline & & Soma & 4,40 \\
\hline
\end{tabular}

Analisando a tabela 9 e a figura 5, apresentados na seção 2.3.3, tentou-se chegar ao posicionamento da categoria de Movimentação Interna no modelo de Pagell et al. (2010). Analisando ambos os eixos não seria possível classificar a categoria dentro do modelo de Pagell et al. (2010) se analisarmos somente os scores encontrados. Em relação ao eixo vertical, ela se enquadraria como Commodity Estratégica e, analisando o eixo horizontal, ela seria considerada como Commodity Transacional.

Este fato pode ser explicado pela natureza específica da atividade de movimentação interna no setor de mineração, já que é uma categoria que eleva muito os riscos a todas as esferas do Tripple Bottom Line mas, ao mesmo tempo, hoje, apresenta um risco de suprimentos moderado baixo. Porém, com base na literatura, analisando as classificações propostas pelo modelo, uma das 
características mais marcantes da Commodity Estratégica é em relação ao risco de fornecimento que o comprador leva de baixo para alto. Analisando a categoria de movimentação interna com base nas entrevistas, constata-se que ela possui um risco de fornecimento baixo, porém, ao incluir a análise das dimensões sociais e ambientais pertencentes ao Tripple Bottom Line e conclusão que as mesmas possuem alto risco dentro da categoria, verifica-se que aumenta a necessidade do investimento no desenvolvimento de relacionamento com os fornecedores e necessidade de levar o grau de risco de fornecimento de baixo para alto já que, existe uma necessidade de diminuir o risco ao Tripple Bottom Line. Para isso, o relacionamento com o fornecedor deve ser muito próximo, desenvolvendo-o e analisando de perto seus dados financeiros, sua dependência em relação à empresa XXX, como ele é visto na sociedade, qual grau de desenvolvimento sustentável que ele se encontra, o que ele faz para diminuir o impacto ambiental na prestação dos serviços entre outros. Este relacionamento é construído ao longo do tempo e, por isso, existe a necessidade de se ter contratos de longo prazo. Assim, o comprador leva esse risco para alto, pois, se este fornecedor sai da base de fornecedores contratados, todo o investimento realizado nele será perdido pela a empresa XXX. Com isso, a classificação mais adequada para a categoria de movimentação interna seria como Commodity Estratégica.

Dentro dessa classificação, é necessário ter contratos de longo prazo para que o desenvolvimento na relação com o fornecedor possa ser realizado, podendo assim diminuir os riscos aos elementos do Tripple Bottom Line dentro desta categoria. Como sugestão inicial, este trabalho exemplifica algumas possíveis ações que podem ser tomadas em conjunto com o fornecedor para a mitigação dos riscos. Em relação aos elementos sociais, podem ser realizados em conjunto ações de desenvolvimento da comunidade local (contratação de mão de obra local para o contrato, investimentos em infraestrutura da comunidade local etc.), programas de monitoramento da saúde de segurança dos colaboradores (workshops, fiscalização dos itens de segurança necessários, exames periódicos para os colaboradores etc.). Em relação aos elementos ambientais podem ser realizados em conjunto palestras sobre desperdício de recursos não renováveis, programas para evitar a geração de resíduos e até o desenvolvimento de novas tecnologias que diminuam esta geração, treinamentos sobre os impactos que aquela atividade causa no meio ambiente e como estes podem ser reduzidos. Em relação ao elemento econômico, 
pode ser analisada a viabilidade de empréstimos pela empresa contratante para que a empresa contratada consiga comprar as máquinas necessárias nas execuções dos serviços com taxas mais baixas que a de mercado, desenvolvimento em conjunto de ações que possam aumentar a vida útil dos equipamentos diminuindo a necessidade de reinvestimento durante a vigência do contrato, desenvolvimento em conjunto de um plano de ação back-up caso ocorra algum problema durante a execução dos serviços que paralisem as atividades contratadas sem ser somente multas contratuais, já que o lucro cessante pela paralização das atividades, é muito maior do que o valor recebido nas aplicação de multas. 


\section{Conclusões e Recomendações}

O presente estudo teve como finalidade principal a aplicação e a avaliação de um modelo de portfólio de compras voltado para sustentabilidade, para análise de uma área de compras de uma empresa mineradora, com a finalidade de criar estratégias para se obter um processo de Compras Sustentáveis e mostrar o uso de uma nova ferramenta para elaboração de estratégias de Compras Sustentáveis, respondendo a questão central: Como os elementos de sustentabilidade devem ser aplicados para a obtenção de uma Compra Sustentável?

Deste modo, para responder esta questão, o estudo foi estruturado com três objetivos secundários: (i) Qual a relação que existe entre sustentabilidade e contratações? (ii) Quais elementos devem ser estudados para a aplicação da sustentabilidade na contratação de serviços? (iii) Os itens que caracterizam uma contratação sustentável devem ser aplicados da mesma maneira para todos os tipos de compras? E o objetivo específico de aplicação do modelo de portfólio com sustentabilidade de Pagell et al. (2010).

Como justificativa para o uso do modelo de Portfolio de Kraljic neste estudo, pode-se citar:

I) Modelo utilizado para elaboração de estratégias de Compras na empresa estudada.

II) Modelo base para elaboração do modelo com sustentabilidade de Pagell et al.(2010)

Foi utilizada a metodologia de estudo de caso por ser esta considerada a mais adequada para o tipo de estudo proposto, que examina um fenômeno atual que foge do controle do pesquisador. Foram realizadas questionários e discussões em profundidade com os analistas que trabalham na categoria de Movimentação Interna da empresa avaliada.

Sobre a relação entre sustentabilidade e contratações, ambos os temas vêm ganhando importância estratégica dentro das organizações nos últimos anos devido às pressões que as empresas vêm sofrendo de seus stakeholders, principalmente em relação à questão do desenvolvimento sustentável onde, os elos econômicos, ambiental e social devem conviver em perfeita harmonia. Assim, como o processo de contratações é considerado como sendo o início do fluxo de materiais e serviços para a empresa, caso este seja sustentável, já será um grande 
avanço para as organizações implementarem sustentabilidade em seus processos e atividades. Hoje, as organizações não possuem expectativa de sobrevivência de longo prazo caso não atendam ao equilíbrio necessário aos elementos do Tripple Bottom Line. O conceito de compras sustentáveis pode ser entendido como uma solução para integrar considerações ambientais e sociais em todas as fases do processo de compra e contratação, visando reduzir impactos sobre a saúde humana, o meio ambiente e os direitos humanos. A prática destas compras permite atender as necessidades específicas dos consumidores finais através da compra do produto/serviço que oferece o maior número de benefícios para o ambiente e para a sociedade. Além disso, é possível reduzir custos já que compras é responsável pelo principal volume de gastos considerando que, em média, 50\% do custo de produção é representado pela aquisição de matérias-primas e serviços.

Dentro do processo de compras, o Tripple Bottom Line pode e deve ser implementado, para que se obtenha um processo de compras sustentável que irá ajudar a empresa a obter vantagem competitiva no mercado em que atua. Abaixo, é resumida a necessidade de cada uma destas dimensões em relação ao processo de compras:

- Social: Necessária para indicar que uma organização examinou sua cadeia de suprimentos garantindo que ela é socialmente responsável e ética, ou seja, que ela não faz mal em relação aos indicadores sociais, tais como as condições de trabalho e os direitos humanos dos trabalhadores. Verificar dentro do processo de contratação os riscos que aquela atividade contratada pode trazer para a comunidade local, e para os fornecedores que irão realizá-la. Não se preocupar apenas com a redução de custos, mas sim com a viabilidade econômica do contrato para não correr riscos de quebrar fornecedores.

- Econômico: Necessária para a redução de custos através de estudos de aquisição de bens e serviços que sejam mais eficientes para operar reduzindo os custos operacionais (incluindo energia, água e tempo). Como os gastos com itens terceirizados, representam um alto percentual em relação ao valor do produto final, qualquer redução de custos dentro destes, impacta diretamente no lucro da empresa. Um processo bem feito não é aquele somente com o preço mais baixo, mas sim aquele que consegue ser sustentável ao longo da vigência do contrato, sem risco de quebra do fornecedor, pleitos ou problemas operacionais devido a preços não contemplados na proposta do fornecedor. Compras deve ter perfeito 
conhecimento do item que está sendo comprado, pois muitas vezes, o valor daquele item em relação ao prejuízo que o mesmo pode causar caso ocorra alguma falha, são muito destoantes.

- Ambiental: Necessária para a contratação de bens e serviços ambientalmente corretos. Estes são definidos como aqueles que têm impacto menor sobre o meio ambiente durante seu ciclo de vida. As principais questões ambientais que precisam ser consideradas ao longo do ciclo de vida do serviço incluem: o consumo/tipo de energia utilizada; uso da água e impactos na qualidade da água; utilização de recursos, incluindo o uso de recursos não renováveis; volume e tipo de resíduos gerados; opções de fim de vida, por exemplo, reciclagem, recuperação de recursos impacto no habitat natural; ruído, poluentes e emissões gerados.

A harmonia entre estes três elementos é essencial para que a empresa alcance o desenvolvimento sustentável. Porém, como mostrado no modelo aplicado de Pagell et al. (2010), para cada tipo de compra, existem características em cada uma destas esferas que devem ser levadas em consideração no planejamento dos processos. De acordo com o modelo aplicado no estudo de caso, para cada tipo de compra existente no modelo de portfólio de Kraljic (1953), existe um tratamento específico no modelo de Pagell et al.(2010). Dentro deste modelo, os itens que devem ser estudados para a aplicação da sustentabilidade em compras são: a ameaça aos elementos do Tripple Bottom Line; Risco de suprimentos e Horizonte de Planejamento. Porém, este modelo não deixa claro qual estratégia adotar para cada classificação em relação aos riscos encontrados.

Dentro do estudo de caso realizado, constatou-se que os contratos da categoria de movimentação interna da empresa XXX, fazem parte do quadrante de alavancagem da matriz de Kraljic. Utilizando esta definição e aplicando o modelo de Pagell et al. (2010), a categoria se enquadra como Commodity Estratégica. Os itens que se enquadram como tal, possuem um risco no fornecimento estratégico, devido a necessidade de investimentos feito pelo comprador no relacionamento com o fornecedor. Esses investimentos são realizados devido a elementos sociais e ambientais que possuem alto risco. Essa iniciativa minimiza as ameaças ao Tripple Bottom Line e cria novas oportunidades de um relacionamento duradouro, mas aumenta o risco de perda de investimento se houver a troca de fornecedor. 
Em relação à categoria de movimentação interna da empresa XXX, a mesma deve criar planos de ação para mitigar os riscos apresentados neste estudo. No modelo de Kraljic (1953), até então aplicado pela empresa XXX, o único risco levantado era em relação ao fator econômico já que o risco de suprimentos era baixo. Porém, ao aplicar o modelo de Pagell et al. (2010), foi constatado que esta categoria de compras está sujeita a um alto risco também nos fatores ambientais e sociais, o que acaba levando o risco de suprimentos de baixo para alto. É necessário criar um planejamento de como mitigar estes riscos, até então desconhecidos dentro do cotidiano desta área de compras. Sem isto, a área de movimentação interna, não poderá se encaixar como área de compras sustentáveis e poderá estar impactando a empresa XXX, para que a mesma tenha resultados inferiores aos possíveis na avaliação de grau de sustentabilidade de suas atividades.

Embora o Estudo de Caso tenha sido aplicado em apenas uma empresa pertencente ao segmento de Mineração, devido ao porte da empresa, ele pode ser considerado como relevante, pois esta empresa além de ter presença mundial é uma das maiores empresas brasileiras. Assim, como houve sucesso na aplicação do modelo no Estudo de Caso para a avaliação da área de Compras de Movimentação Interna sob aspecto da sustentabilidade, este modelo de Portfólio com sustentabilidade poderá ser aplicado em outras empresas, para avaliação de outas áreas de Compras de diversos segmentos.

\subsection{Recomendações para Estudos Futuros}

Observou-se neste estudo que as empresas vêm apresentando uma evolução tanto no processo de compras como no processo de inclusão da sustentabilidade em seus processos. No entanto, o estudo de caso teve como foco apenas uma empresa pertencente ao setor de mineração brasileiro, destinada a trazer um primeiro entendimento da aplicação de sustentabilidade dentro do processo de compras. Porém, alguns setores da economia, são mais cobrados que outros para aplicação da sustentabilidade. Este conceito está mudando aos poucos, mas ainda é observado este fato. Como o setor escolhido foi o de mineração, grande alvo de pressões em relação à sustentabilidade não só ambiental como social e econômica devido à influência que este setor gera na sociedade em geral, seria interessante 
realizar este estudo em um setor com menores impactos nas dimensões do Tripple Bottom Line para avaliação se o tema compras sustentáveis é viável de aplicação em outros setores da economia uma vez que este tema é muito recente e poucos estudos foram realizados sobre a aplicação do mesmo.

Finalmente, um modelo que complementasse o modelo proposto por Pagell et al. (2010), que definisse estratégias para as características encontradas como risco, é necessário. Por exemplo, no estudo de caso apresentado foi constatado que todos os elementos do Tripple Bottom Line apresentam alto risco dentro da categoria de movimentação interna. Porém, como cada um deve ser tratado dentro do tema de compras sustentáveis não é definido pelo modelo existente. É necessário abrir para todas as classificações encontradas neste modelo estratégias para os possíveis cenários e planos de monitoramento destas. O único ponto citado como estratégia para a classificação encontrada no estudo de caso é a necessidade de realizar um investimento no relacionamento com o fornecedor de maneira a minimizar os riscos encontrados, mas, como este investimento deve ser realizado não é dito e nem como deve ser aplicado em relação a cada dimensão do Tripple Bottom Line. 


\section{Referências Bibliográficas}

AGNDAL, H; AXELSSON B.; LINDBERG N.; NORDIN F. Trends in Service Sourcing Practices. Journal of Business Market Management, v. 1, n. 3, p. 187207. 2007.

ALANIZ, S.; Shuffield, E. Applications to Turn Direct Materials Procurement into a Competitive Advantage. 2001. Disponível em <www.atkearneyprocurementsolutions.com/news/stephensreport013001.pdf>. Acesso em: 20/03/2014.

ALMEIDA, F. O bom negócio da sustentabilidade. Rio de Janeiro: Nova Fronteira. 2002.

AMINDOUST, A; AHMED, S; SAGHAFINIA, A; BAHREININEJAD, A. Sustainable Supplier Selection: A ranking model based on fuzzy inference system. Applied Soft Computing v12, n6, p 1668-1677. 2012.

ANDRADE, R.O.B. de; TACHIZAWA, T.; CARVALHO, A.B. de. Gestão Ambiental: enfoque estratégico aplicado ao desenvolvimento sustentável. São Paulo: Makron Books. 2000.

ANDRADE, G.C. Gestão Estratégica de Suprimento em uma empresa do setor elétrico brasileiro. Dissertação (Mestrado em Engenharia de Produção)Universidade Federal do Rio de Janeiro. 2012.

ARAYA, M.. Ensaio: A política da boa transparência. Adiante: inovação para a sustentabilidade. São Paulo: n.0, p.36-39, 2005.

ARNOLD, J. R. T. Administração de Materiais. São Paulo: Atlas. 1999.

AXELSSON, B.; WYNSTRA, F. Buying Business Services. West Sussex: John Wiley \& Sons. 2002.

AZEVEDO, A.L.V. Indicadores de sustentabilidade empresarial no Brasil: uma avaliação do Relatório do CEBDS. Revista Iberoamericana de Economia Ecológica; Vol. 5: 75-93. 2006.

BACHA, M.L.; SANTOS, J.; SCHAUN, A. Considerações Teóricas sobre o Conceito de Sustentabilidade. In: VII Simpósio de Excelência em Gestão e Tecnologia. Resende: SEGeT. 2010

BAILY, P.; FARMER, D.; JESSOP, D.; JONES D.; Compras: princípios e administração. São Paulo: Editora Atlas. 2000 
BALLOU, R.H. Gerenciamento da Cadeia de Suprimentos: planejamento, organização e logística empresarial. Porto Alegre: Bookman. 2001.

BALLOU R.H. Business Logistics Management: Planning, Organizing and Controlling the Supply Chain. $5^{\text {th }}$ edition. New Jersey. Prentice-Hall. 2004.

BARBOSA, P.R. A. Índice de sustentabilidade empresarial da bolsa de valores de São Paulo (ISE-BOVESPA): exame da adequação como referência para aperfeiçoamento da gestão sustentável das empresas e para formação de carteiras de investimento orientadas por princípios de sustentabilidade corporativa. Dissertação (Mestrado em Administração) - Universidade Federal do Rio de Janeiro - UFRJ, Instituto COPPEAD de Administração. 2007.

BCSD Portugal- Conselho Empresarial para o Desenvolvimento Sustentável. Procurement Sustentável.2008. Disponível em < http://www.bcsdportugal.org/wpcontent/uploads/2013/11/YMT-2008-Procurement-sustentavel.pdf $>$. Acesso em 20/04/2014.

BENSAOU, M. Portfolios of Buyer-Supplier Relationships. Sloan Management Review, v. 40, n. 4, 35-41. 1999.

BERTAGLIA, P. R. Logística e gerenciamento da cadeia de abastecimento. São Paulo: Saraiva. 2006.

BM\&FBOVESPA. Novo Valor: Sustentabilidade nas empresas como começar, quem envolver e o que priorizar. São Paulo. 2010.

BOWEN, F. E.; COUSINS, P. D.; LAMMING, R. C.; FARUK, A. C. The role of supply management capabilities in green supply. Production and Operations Management, v. 15, n. 2, p. 63-75. 2001

CANIËLS, M.; GELDERMAN, C. Purchasing strategies in the Kraljic Matrix A power and dependence perspective. Journal of purchasing and supply management, v. 11, p. 141-155. 2005.

CARR, A.S.; SMELTZER L. R. The Relationship of Strategic Purchasing to Supply Chain Management. European of Purchasing \& Supply Management, p.43-51. 1999.

CARTER, C.R.; ELLRAM, L.M.; READY, K.J. Environmental purchasing: bench-marking our German counterparts. International Journal of Purchasing and Materials Management 34 (4), 28-38.1998.

CARTER, J. R.; NARASIMHAN, R. Is Purchasing really strategic? International Journal of Purchasing and Materials Management, v. 32, p. 20-28. 1996. 
CARVAlHo, J. Logística e Gestão da Cadeia de Abastecimento, Lisboa, Edições Sílabo, Lda.2010.

CMMAD- COMISSÃO MUNDIAL SOBRE MEIO AMBIENTE E DESENVOLVIMENTO. Nosso Futuro Comum. Meribérica/Líber, Lisboa. 1991.

CNI - Confederação Nacional da Indústria. Estratégias Corporativas de Baixo Carbono: Gestão de Riscos e Oportunidades. Brasília. 2011.

COOPER, M. C.; LAMBERT, D. M.; PAGH, J. D. Supply Chain Management: more than a new name for logistics. The International Journal of Logistics Management, v. 8, n. 1, p. 1-13. 1997.

COUSINS, P. D.; SPEKMAN, R. Strategic Supply and the management of interand intra-organisational relationships. Journal of Purchasing and Supply Management, v.9, p. 19-29. 2003.

CRAWFORD, J.. Sustainability And Planning: RTPI Debate Seeks To Clarify Position. Planning. London, n. 1595. 2004.

DAHLMANN， F.; BRAMMER， S.; MILLINGTON， A. Implementing sustainable sourcing Environmental management in the United Kingdom: new survey evidence. Management Decision 46 (2), 2008.

DIAS, M. A. P. Administração de Materiais. São Paulo: Atlas. 1995..

DOBLER, D. W.; BURT, D. N. Purchasing and supply management: text and cases. 6 ed. New York: McGraw-Hill. 1996.

DONAIRE, D. Gestão ambiental na empresa. 2.ed. São Paulo: Atlas. 1999.

DRIEDONKS, A. D.; GEVERS, J. M. P.; WEELE, A. V. Managing sourcing team effectiveness: the need for a team perspective in purchasing organizations. Journal of Purchasing and Supply Management, v. 16, n. 2, p. 109-117. 2010.

DUBOIS, A.; PEDERSEN, A.C. Why relationships do not fit into purchasing portfolio models: a comparison between the portfolio and industrial network approaches. European Journal of Purchasing \& Supply Management, 8, p.35-42. 2002.

ELKINGTON, J. Partnerships from cannibals with fork: the triple bottom line of 21 - century business. Environmental Quality Management, v 8, n1, p 37-51. 1998.

ENNIS-REYNOLDS, G.. Sustainable Development And Multiplexes. Journal of Leisure Property. London, n. 4. 2002 
ENRÍQUEZ, M.A.;Fernandes, F.R.; Alamino, R de.C.J. A mineração das grandes minas e as dimensões da sustentabilidade.Rio de Janeiro: CETEM/MCTI, p. $1-17.2011 . \quad$ Disponível em http://www.cetem.gov.br/recursos_minerais_sustentabilidade.php. Acesso em $15 / 06 / 2014$

FEARON, H. History of Purchasing. Journal of Purchasing, p. 44-50, feb. 1968.

FERREIRA, L C. Sustentabilidade: uma abordagem histórica da sustentabilidade. In: BRASIL. Encontros e Caminhos: Formação de Educadoras(es) Ambientais e Coletivos Educadores. Brasília: Ministério do Meio Ambiente. 2005.

FRANKEL, R.; BOLUMOLE, Y.A.; ELTANTAWY, R.A.; PAULRAJ, A.; GUNDLACH, G.T. The domain and scope of SCM's foundational disciplinesinsights and issues to advance research. Journal of Business Logistics, v. 29, n.1, p. 1-30. 2008.

GAITHER, N.; FRAZIER, G. Administração da produção e operações. São Paulo: Pioneira/Thomson Learning. 2001.

GALEOTTI, M.; KEMFERT, C. Interactions Between Climate And Trade Policies: A Survey. Journal of World Trade. New York, v. 38, n. 4. 2004.

GELDERMAN, C.J.; VAN WEELE, A.J. Strategic direction through purchasing portfolio management: A case study. Journal of Supply Chain Management, v. 38, n. 2, p. 30-37. 2002.

GELDERMAN, C.J.; VAN WEELE, A.J. Handling Measurement Issue and Strategic Directions in Kraljic's Purchasing Portfolio Model. Journal of Purchasing \& Supply Management, 9, p. 207-216. 2003.

GIL, A .C. Como elaborar projetos de pesquisa. $5^{\text {a }}$ edição. Editora Atlas. São Paulo, SP. 2007.

GRONHAUG, K.; VENKATESH, A. Needs and need recognition in organisational buying. European Journal of Marketing, v. 25, n. 2, p. 17-32. 1991.

HADELER, B.J.; EVANS, J.R. Supply Strategy: Capturing the Value. Industrial Management, v. 36, n. 4, p. 3-14. 1994

HANDFIELD, R.B.; WALTON, S.V., SEEGERS, L.K., MELNYK, S.A. Implementing sustainable sourcing: Green value chain practices in the furniture industry. Journal of Operations Management 15 (4), 293-315. 1997. 
HANDFIELD, R.B.; SROUFE, R.; WALTON, S. Integrating environmental management and supply chain strategies. Business Strategy and the Environment 1(1), 1-19.2005.

HARLAND, C.M.; LAMMIG, R.C.; COUSINS, P.D. Developing the concept of supply strategy. International Journal of Operations and Production Management 19 (7), 650-673.1999.

HAYES, R.H.; WHEELWRIGHT, S.C. Restoring our Competitive EdgeCompeting Through Manufacturing. Jhon Wiley \& Sons, Inc., USA. 1984.

HILL, J. A. The Purchasing Revolution. Journal of Purchasing Management, p. 18-19, Summer. 1975.

HILSON, G. Sustainable Development in the Mining Industry: Clarifiyng The Corporate Perspective, Resources Policy.. p. 227-238. 2000.

IRELAND, R. D.; REUTZEL, C. R.; WEBB, J. W. Entrepreneurship Research in AMJ: What Has Been Published, and What Might the Future Hold? Academy of Management Journal, Vol. 48, Issue 4, p556-564, 9p. 2005.

ITAÚ. Relatório Macro Setorial de Mineração. 2013. Disponível em $<$ https://www.itau.com.br/_arquivosestaticos/itauBBA/contents/common/docs/20 1306_MACRO_Setorial_Mineracao_r.pdf>. Acesso em 13/06/2014.

IUCN- International Union for the Conservation of Nature and Natural Resources. World's Conservation Strategy. 1980.

KARNA, J; HANSEN, E.; JUSLIN, K. Social Responsability In Environmental Marketing Planing. European Journal of Marketing. Bradford, v.37, n. 5/6. 2003.

KATO, C. A. Arquitetura e sustentabilidade: projetar com ciência da energia. Dissertação de mestrado. Arquitetura e Urbanismo. Universidade Presbiteriana Mackenzie. 2008

KRALJIC, P. Purchasing must become supply management, Harvard Business Review, v. 61, n. 5, p. 109-117, September-October. 1983.

KRAUSE, D.R.; VACHON, S.; KLASSEN, R.D. Special topic forum on sustainable supply chain management: introduction and reflections on the role of purchasing management. Journal of Supply Chain Management 45 (4), 1825.2009.

LACY, P. Qual será o futuro da Sustentabilidade? HSM Online, disponível em <http://br.hsmglobal.com/notas/58260-qual-sera-o-futurodasustentabilidade?utm_source=news_sustentabilidade_070710\&utm_medium=n 
ews_sustentabilidade_070710\&utm_content=news_sustentabilidade_00710_qualsera-o-futuro-da-

sustentabilidade\&utm_campaign=news_sustentabilidade_070710>, acessado em: 20/05/2014

LAIOS, L. G.; MOSCHURIS, S. J. The influence of enterprise type on the purchasing decision process. International Journal of Operations \& Production Management, v. 21, n. 3, p. 351-372. 2001.

LANG, J. Gestão ambiental: estudo das táticas de legitimação utilizadas nos relatórios da administração das empresas listadas no ISE. Dissertação de mestrado. Universidade Regional de Blumenau. 2009

LEIRIA, J. S. Terceirização: uma alternativa de flexibilidadeempresarial. 5 ed. Porto Alegre: Sagra: DC Luzzatto. 1992.

LIMA, A.P. de; ROCHA, F.M.; TREINTA, F.T. LIMA, G.B.A. Implementação do conceito de Triple Bottom Line em empresa de pequeno porte. Niterói: Universidade Federal Fluminense. 2009.

MCKINSEY GLOBAL INSTITUTE. Urban world: cities and the use of the consuming class. 2012. Disponível em < http://www.mckinsey.com/insights/urbanization/urban_world_cities_and_the_rise _of_the_consuming_class>. Acesso em 13/06/2014

MARTINS, P.G.; ALT, P.R.C. Administração de Materiais e Recursos Patrimoniais. Editora Saraiva. 2001.

MARTINS, R.C. Estratégia de compras na indústria brasileira de higiene pessoal e cosméticos: um estudo de casos. Dissertação de Mestrado. Universidade Federal do Rio de Janeiro Instituto Coppead de Administração. 2005.

MASULLO, D. G. Condicionamento da Divulgação de Informações sobre Responsabilidade Ambiental nas Grandes Empresas Brasileiras de Capital Aberto: internacionalização e setor de atuação. Dissertação (Mestrado em Administração) - Instituto COPPEAD de Administração, Universidade Federal do Rio de Jane iro, Rio de Janeiro, 2004.

MEEHAN, J. ; BRYDE, D. Sustainable Procurement Practice. Business Strategy and the Environment, v. 20, p. 94-106. 2011.

MELO NETO, F.P. de: FROES, C.. Gestão da responsabilidade social corporativa: o caso brasileiro. 2.ed. Rio de Janeiro: Qualymark, 2001. 
MELO NETO, F.P. de; BRENNAND, J.M. Empresas Socialmente Sustentáveis: o novo desafio da gestão moderna. Rio de Janeiro: Qualitymark. 2004.

MONCZKA, R. M.; TRENT, R.; HANDFIELD, R. Purchasing and supply chain management. 2 ed. Cincinnat: South-Western, College Publishing. 2002

MONCZKA, R.M.; HANDFIELD R.B.; GIUNIPERO. L.C.; PATTERSON J.L. Purschasing and Supply Chain Management. Mason, Ohio: South-Western. 2009. MONTIBELLER-FILHO, G. O movimento ambientalista e o desenvolvimento sustentável-DS. In: MONTIBILLER-FILHO, G. O mito do desenvolvimento sustentável: meio ambiente e custos sociais no moderno sistema produtor de mercadorias. Florianópolis: Editora da UFSC. 2001.

MOTA, E. A. D. O papel das organizações no desenvolvimento sustentável: um olhar sobre a perspectiva da responsabilidade social. Centro Universitário Franciscano, Paraná, 16 p, 2006. Disponível em: $<$ http://www.unifae.br/publicacoes/pdf/sustentabilidade/eduardo_oppapeldasorgan izacoes.pdf >. Acesso em: 10/04/2014

MOURA, L. G. V.Indicadores para a avaliação da sustentabilidade em sistemas de produção da agricultura familiar: o caso dos fumicultores de Agudo. Dissertação de mestrado. Desenvolvimento Rural. Universidade Federal do Rio Grande do Sul. 2002

MOYNIER, M.R.; FIGUEIREDO E.; MOYNIER R.M.L.A.;ROCHA M.H.P. Gerenciamento de Projetos: A ISO 26000 como Norteadora da Proposta de Inserir a Responsabilidade Social como Área de Conhecimento. IX Congresso Nacional de Excelência em Gestão. 2013.

NARASIMHAN, R. An Analytical Approach to Supplier Selection. Journal of Purchasing and Materials Management, v. 19, p. 27-32. 1983.

NARASIMHAN, R.; CARTER, J. R. Linking business unit and material sourcing strategies. Journal of Business Logistics, v. 19, n. 2, p. 155-169. 1998.

NEIVA, S.B.; GOMES, L.F.A.M. A aplicação da teoria da utilidade multiatributo à escolha de um software de e-procurement. Disponível em <http://www.abepro.org.br/biblioteca/ENEGEP2002_TR70_0853.pdf>Acesso em 05/01/2014.

NEVES, L.W. ; HAMACHER, S. O processo de compras e a logística integrada. Revista Tecnologística. São Paulo, Publicare Editora, p. 140-145. 2004. 
NORDIN, F. Linkages between service sourcing decisions and competitive advantage: a review, propositions, and illustrating cases. International Journal of Production Economics, v. 114, n. 1, p.40-55. 2008.

OGDEN, J. Supply Base Reduction Within Supply Base Reduction. Practix, v.6. 2003.

OLSEN, R. F.; ELLRAM, L. M. A Portfolio Approach to Supplier Relationships. Industrial Marketing Management, v. 26, p. 101-113. 1997.

OSIRO, L.; Uso da lógica fuzzy para avaliação e desenvolvimento de fornecedores baseado em modelos de portfólio, Universidade de São Paulo. 2013. Disponível em <file:///C:/Users/01506109/Downloads/LauroOsiroDEFINITIVO.pdf>. Acesso em 20/04/2014.

PAGELL, M.; WU, Z. Building a More Complete Theory of Sustainable Supply Chain Management Using Case Studies of Ten Exemplars. Journal of Supply Chain Management, 45, p. 37-56. 2009.

PAGELL, M.; WU, Z.; WASSERMAN, M.E. Thinking differently about purchasing portfolios: an assessment of sustainable sourcing. Journal of Supply Chain Management, Vol. 46 No. 1, pp. 53-73. 2010.

PEREIRA, M. O uso da curva ABC na empresa.2005. Disponível em <http:/www. kplus.cosmo.com.br/material.asp?co=5Srv=Vivencia $>$. Acesso em: 20/07/2014.

PORTER, M. E. Estratégia Competitiva - Técnicas para análise de indústrias e da concorrência. 18 ${ }^{a}$ Edição. São Paulo-SP: Campus. 1986.

PORTER, M.E.; VAN DER LINDE, C. Green and competitive: Ending the stalemate. Harvard Business Review 73 (5), 120-134.1995.

PORTER, M.E.; KRAMER, M. Strategy and Society: The Link Between Competitive Advantage and Corporate Social Responsibility. HBR Spotlight, Harvard Business Review. 2006.

POZO, H. Administração de Recursos Materiais e Patrimoniais - uma abordagm logística. 1. ed. São Paulo: Editora Atlas AS, v. 1. 210p . 2001.

QGCPO- Queensland Government Chief Procurement Office. Sustainable procurement- A working definition. 2012. Disponível em < http://www.hpw.qld.gov.au/SiteCollectionDocuments/SustainableProcurementDef inition.pdf>. Acesso em 20/04/2014 
RICHARDSON, R. Pesquisa Social: Métodos e Técnicas. $3^{\mathrm{a}}$ edição. Editora Atlas. São Paulo, SP. 1999.

ROCHA, T.A.P. Análise do relatório GRI enquanto ferramenta para a mensuração da Sustentabilidade empresarial.2012. Disponível em: < file://C:/Users/01506109/Downloads/TatianaACRocha_Corrigida.pdf>. Acesso em 20/08/2014.

SACHS, I. Desenvolvimento Sustentável, Bio-Industrialização Descentralizada e Novas Configurações Rural-Urbanas. Os casos da Índia e do Brasil. In Vieira, P. F. e Weber, J. (orgs.). Gestão de recursos naturais renováveis e desenvolvimento: novos desenvolvimentos para a pesquisa ambiental. São Paulo: Cortez. 1997

SANCHES, C. Gestão Ambiental Proativa. ERA- Revista de Administração de Empresas. São Paulo, v.40, n1. p.76-87. 2000.

SANTOS, A.P.L. Estruturação do processo de compras de materiais para viabilizar a implantação do comércio eletrônico na indústria da construção civil. Dissertação de Mestrado disponível em: <http://www.ppgcc.ufpr.br/dissertacoes/d0001.pdf> Universidade Federal do Paraná, Faculdade de Engenharia, Curitiba (PR). 2002. Acesso em 02/02/2014. SANTOS, R.S.; FORESTI, L.F.; SANTOS NETO, A.M.V. dos. Guia de Compras Públicas Sustentáveis para a Administração Federal. Brasília. 2010. Disponível em

http://cpsustentaveis.planejamento.gov.br/wpcontent/uploads/2010/06/Cartilha.pd f>. Acesso em 20/04/2014

SAVITZ, A. W.; WEBER, K. The Triple Bottom Line: how today's best-run companies are achieving economic, social, and environmental success - and how you can too. San Francisco: Jossey-Bass, 2006

SCHALTEGGER, S.; BURRITT, R.; PETERSEN, H. An introduction to corporate environmental management: striving for sustainability. Sheffield: Greenleaf. 2003.

SCHNEIDER, L.; WALLENBURG, C. M. Implementing sustainable sourcingDoes purchasing need to change? Journal of Purchasing and Supply Management, v.18, no.4, pp.243-257. 2012.

SGARBI, V.S.; LIMA, M.T.A.; SANTOS, C.F.S.O.; FALCÃO, M.C.Os Jargões da Sustentabilidade: uma Discussão a partir da Produção Científica Nacional, Engema. 2008. 
SHARMA, S.; HENRIQUES, I. Stakeholder influences on sustainability practices in theCanadian forest products industry. Strategic Management Journal 26 (2), 159-180. 2005.

SILVA, M.A.R da; DRUMMOND, J.A. Certificações socioambientais: desenvolvimento sustentável e competitividade da indústria mineira na Amazônia. Cadernos EBAPE.Br, Brasília. 2005. Disponível em: <http://www.ebape.fgv.br/cadernosebape>. Acesso em 20/06/2014.

SILVA, D. da, Sustentabilidade Corporativa. In: Anais VI Simpósio de Excelência em Gestão e Tecnologia - SEGeT, Resende, RJ. 2009.

SIMPSON, D.; POWER, D.; SAMSON, D.Greening the automotive supply chain: a relationship perspective. International Journal of Operations \& Production. 2007.

SOUZA, M.T.S. de. Modelo de organização sustentável: indicadores setoriais dominantes de sustentabilidade - análise de um segmento do setor de alimentação. In: ENANPAD, Anais , Florianópolis. 2000

TATE, W.; ELlRAM, L.; KIRCHOFF, J. Corporate Social Responsibility Reports: A Thematic Analysis Related to Supply Chain Management. Journal of Supply Chain Management, 46(1), 19-44.2010.

TERPEND, R.; KRAUSE, D.R.; DOOLEY, K.J. Managing Buyer-Supplier Relationships: Empirical Patterns of Strategy Formulation in Industrial Purchasing. Journal of Supply Chain Management, 47, p. 73-94. 2011.

TUTILLO, J.A.B. Análise dos Indicadores de Sustentabilidade da Global Reporting Initiative nas Lavanderias de Jeans da Cidade de Toritama no Polo Têxtil do Agreste Pernambucano. 2012. Disponível em: < http://www.ppgep.org.br/dissertacoes/MA-0265.pdf>

TUTTLE, T.; HEAP, J. Green productivity: moving the agenda. International Journal of Productivity and Performance Management 57 (1), 2008

URSINI, T.R.; SEKIGUCHI, C. Desenvolvimento sustentável e responsabilidade social: rumo à terceira geração de normas ISO. In: Uniemp Inovação: Inovação.2005.

VALE. Perspectivas da Mineração no Brasil. 2013. Disponível em < http://www.vale.com/EN/investors/Presentationwebcasts/Presentations/PresentationDocs/130924As_perspectivas_da_mineracao_ no_Brasil_PRMF.pdf>. Acesso em 13/06/2014. 
WCED- WORLD COMMISSION ON ENVIRONMENT AND DEVELOPMENT. Our Common Future. Oxford and New York: Oxford University Press. 1987.

WEELE, A.V. Purchasing and Supply Chain Management. London: Thomson Learning. 2002.

WEELE, A. V. Purchasing and Supply Chain Management: analysis, strategy, planning and practiced. Hampshire, UK: Cengage Learning EMEA, 2010.

WISNER, J.D.; STANLEY, L.L. Process Management: Creating Value Along the Supply Chain; Texts \& Cases, Thomson South-Western. 2007.

WU, H.J., DUNN, S.C. Environmentally responsible logistics systems. International Journal of Physical Distribution \& Logistics Management 25 (2),2038.1995 .

YIN, R. K. Estudo de Caso: Planejamento e Métodos. $3^{\text {a }}$ edição. Porto Alegre, Brasil. Bookman. 2005. 


\section{Anexo I: Modelo de Olsen \& Ellram (1997)}

Este método é baseado no portfólio de Kraljic (1983), contudo, possui um propósito claro de envolver aspectos de parcerias e investimentos em relacionamentos com os fornecedores. Já Kraljic (1983), conforme descrito anteriormente, pautou-se no usufruto do poder de compra. Com o objetivo de estabelecer um método capaz de auxiliar os gestores a gerenciar diferentes tipos de relacionamentos com os fornecedores, Olsen \& Ellram (1997) definiram três passos descritos a seguir:

Passo 1: Analisar as compras da empresa de acordo com a importância estratégica da compra e a dificuldade de gerenciá-la. Este passo consiste em posicionar as compras na matriz de Kraljic (1983) sob os eixos de Importância Estratégica da Compra e de Dificuldade de Gerenciá-la (Figura 11). Para isto, cada eixo foi dividido em fatores e cada fator apresenta seus critérios de avaliação. O eixo horizontal de Importância Estratégica está dividido em três fatores - de competência, econômico e de imagem - e para cada um deles foi criada pelos autores uma lista de critérios para avaliar cada um destes fatores conforme apresentada a seguir.

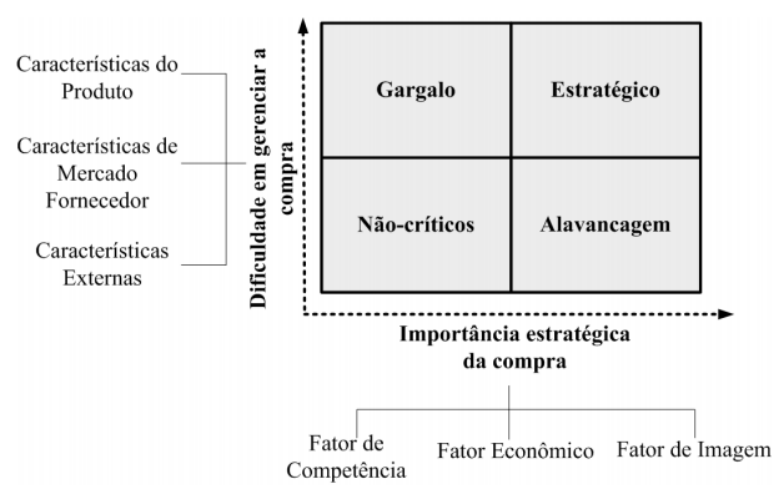

Figura 11- Matriz Adaptada de Kraljic Fonte: Olsen \& Ellram (1997)

O fator de competência possui três critérios sugeridos pelos autores. Estes critérios visam investigar e avaliar a participação do item comprado na competência do negócio e tecnológica da empresa, os quais são:

1. O nível em que a aquisição faz parte das competências centrais;

2. A aquisição melhora o conhecimento da organização compradora;

3. A aquisição aumenta a força tecnológica da organização compradora. 
Em relação ao fator econômico, há quatro critérios sugeridos. O objetivo é entender e avaliar a participação do item comprado na rentabilidade da empresa.

1. Volume ou valor monetário das compras;

2. O nível em que a aquisição faz parte do produto final com alto valor agregado;

3. O nível em que a aquisição faz parte do produto final com boa lucratividade;

4. Criticidade da aquisição para obter poder de compra com o fornecedor para outras aquisições.

Por fim, o último fator deste eixo, é o fator de imagem o qual possui dois critérios sugeridos, com a finalidade de avaliar o impacto do item comprado na imagem da empresa: Imagem / marca críticas; Riscos ambientais/ de segurança

O eixo vertical, Dificuldade de Gerenciar a Compra, é medido por três fatores - Características do Produto, características do Mercado Fornecedor e Características Externas.

O fator de Características do Produto avalia a complexidade do item comprado. Por exemplo, se ele passa por frequentes inovações tecnológicas ou se produto tem uma tecnologia de alta complexidade, será atribuído um valor alto ao fator característica do produto. Os critérios sugeridos são: Novidade; Complexidade.

Com relação ao fator de Característica do Mercado Fornecedor, os critérios sugeridos visam avaliar o quanto à empresa está dependente de um determinado fornecedor por questões do mercado e pela competência técnica e comercial do fornecedor. São eles: Poder dos fornecedores; Competência técnica e comercial do fornecedor.

O último fator componente deste eixo é Características Externas. Características externas envolvem toda a avaliação de risco e incerteza associada à compra. Inclui riscos decorrentes do comportamento oportunista do mercado fornecedor, da incerteza de oferta e de preços, e também a incerteza técnica da produto/serviço fornecido. Risco; Incerteza.

Com relação a estes critérios, os autores alertam para que o ajuste destes seja feito de acordo com a organização, porque eles não são abrangentes e podem variar conforme aplicação. Além disto, para classificar as compras no método de portfólio, a empresa precisa atribuir pesos aos critérios e fatores baseados na 
percepção dos gestores e informações da organização. Neste modelo é usado o método de Narasimhan (1983). Sumarizados os dados em um único score, é possível estabelecer a posição da compra entre as quatro categorias - Não críticos, Alavancagem, Gargalo e Estratégico.

Após a atribuição e cálculo dos pesos e valores, posiciona-se cada item comprado dentro de uma das quatro categorias:

A categoria de alavancagem é composta pelas compras que são facilmente gerenciáveis, entretanto são importantes estrategicamente para as empresas. Geralmente, os volumes de compras desta categoria são altos, portanto deve-se trabalhar o relacionamento com os fornecedores para baixar os custos, reduzindo estoques, custos de transporte e materiais. É importante criar o relacionamento com respeito mútuo e transmitir as necessidades futuras o que pode ser estabelecido por contrato.

As compras com baixo valor estratégico e facilmente gerenciáveis são chamadas de não críticas. A ação recomendada é a de reduzir os custos administrativos para esta categoria. Em alguns casos, para este objetivo, será necessário reduzir o $\mathrm{n}^{\mathrm{o}}$ de fornecedores e padronizar os itens de compras.

As compras com baixo valor estratégico, mas com difícil gerenciamento são chamadas de gargalo. A empresa deve estabelecer um relacionamento próximo com fornecedor focado na engenharia e no envolvimento do fornecedor. Neste caso, o fornecedor deveria ser visto como uma extensão natural da empresa.

Por último, a categoria estratégica contempla a alta dificuldade de gerenciamento e o alto valor estratégico. A empresa deve gerenciar suas compras através do relacionamento mais próximo, priorizando o envolvimento do fornecedor no desenvolvimento de produtos, no valor de longo prazo e na melhoria do processo de suprimentos a fim de reduzir custos.

As recomendações para categoria foram apresentadas pelos autores com a finalidade de explanar os conceitos de cada uma das categorias. Sendo assim, as recomendações variam caso a caso dependendo dos pesos e avaliações de cada um dos fatores.

Passo 2: Analisar os relacionamentos com o fornecedor atual através da atratividade relativa do fornecedor e da força do relacionamento. A fim de analisar os relacionamentos com os fornecedores, Olsen \& Ellram (1997) fazem uso de uma representação gráfica baseada em uma matriz de duas dimensões - 
atratividade relativa do fornecedor e da força do relacionamento - e o tamanho de cada círculo é o recurso alocado no relacionamento (Figura 12). Para determinar a dimensão de atratividade relativa, as empresas deveriam estabelecer e avaliar fatores de ordem financeira e econômica, de desempenho, tecnológico, organizacional e outros. Neste passo, também é sugerido uma lista de critérios assim como no passo 1. Já a dimensão de força do relacionamento possui fatores econômicos, de cooperação e das distâncias (geográficas, sociais e tecnológicas). Da mesma maneira do primeiro passo, os pesos são atribuídos e calculados pelo método de Narasimhan (1983) e a avaliação do relacionamento é feita para o posicionamento conforme ilustrado na Figura 12.

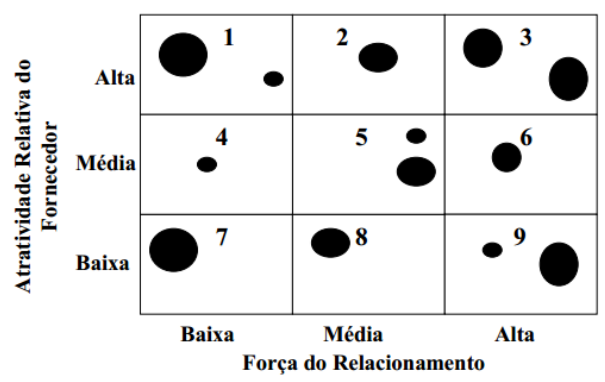

Figura 12- Análise do Relacionamento com o Fornecedor Fonte: Olsen \& Ellram (1997)

Passo 3: Desenvolver o plano de ações

Neste passo, são estabelecidas as ações segundo as informações indicadas nas duas matrizes dos passos anteriores. Algumas das diferentes situações e ações estratégicas estão descritas a seguir agrupadas a cada três células.

Célula 1, 2 e 4 - Grupo 1 é composto por células cuja atratividade do fornecedor está entre média e alta e a força do relacionamento de média a baixa. Para itens estratégicos, é aconselhável fortalecer o relacionamento e manter o fornecedor leal. Um relacionamento pode ser fortalecido por meio da intensificação da comunicação, fornecimento de volume maior ou envolvendo o fornecedor no desenvolvimento de um produto. Caso os itens sejam não críticos ou de alavancagem, o plano de ações deve contemplar estratégias que não impõe a aplicação de um número maior de recursos no relacionamento, como exemplo viável, seria o aumento do volume a fim de fortalecer o relacionamento.

Célula 3, 5 e 6- Grupo 2 contém as células cuja atratividade do fornecedor está entre média e alta e a força do relacionamento de média a alta. Independentemente do tipo do item, a estratégia recomendada seria realocar recursos para manter a 
força do relacionamento. Contudo para itens não críticos e de alavancagem, a empresa deveria considerar redução de recursos para gerenciar o relacionamento. Pois, o retorno de um relacionamento muito sólido é relativamente baixo nestes casos.

Célula 7,8 e 9- Grupo 3 é formado pelas células cuja atratividade do fornecedor é baixa e a força do relacionamento varia de baixa a alta. Estes relacionamentos demandam atenção especial, pois uma das estratégias plausíveis para este caso seria a troca de fornecedor. Todavia, para itens estratégicos ou de gargalo é crucial o desenvolvimento de um plano de ação que contemple formas de assegurar a entrega ou criarem substitutos. Este plano de ação também inclui a ação de aumentar a atratividade do fornecedor, o que, muitas vezes, é mais que eficiente do que estabelecer um relacionamento com um novo fornecedor. 


\section{Anexo 2: Método de Narasimhan (1983)}

Neste anexo será descrita a metodologia apresentada por Narasimhan (1983). Esta pode ser usada para atribuir pesos a fatores que descrevam uma única dimensão. Em vez de comparar todos os fatores e critérios juntos, o método sugere que sejam comparados isoladamente de acordo com o nível hierárquico. Para explicar o método de Narasimhan (1983), utiliza-se o modelo de Olsen \& Ellram (1997) apresentado no Anexo I. O eixo vertical da matriz de Olsen \& Ellram (1997), Dificuldade de Gerenciar a Compra, apresenta uma hierarquia de três níveis conforme pode ser visto na Figura 13.

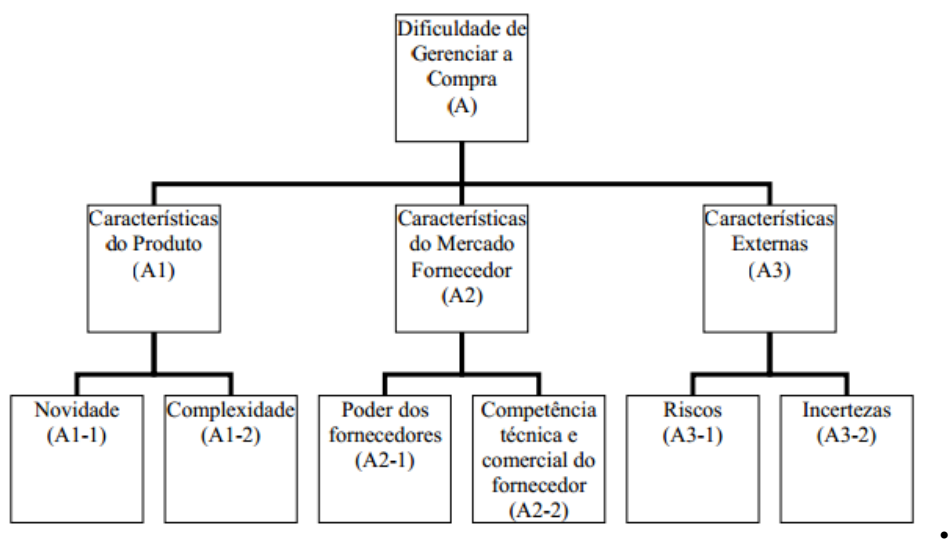

Figura 13- Hierarquia dos Fatores do Eixo Vertical Fonte: Olsen \& Ellram (1997)

O objetivo deste método é determinar o peso de cada fator nos níveis mais baixos. Por exemplo, deve-se atribuir pesos aos critérios novidade (A1-1) e complexidade (A1-2) comparáveis entre si. Já o peso de Característica do Produto (A1) é avaliado em comparação com os fatores Característica do Mercado Fornecedor (A2) e Características Externas (A3).

Esta forma de comparação isolada por conjunto de sucessores na hierarquia reduz a complexidade de uma atribuição pesos. A complexidade da análise seria grande se o método fosse atribuir pesos aos seis fatores do terceiro nível da árvore em uma só vez. A Figura 14 apresenta o método para calcular os pesos dos fatores. Primeiramente, todos os fatores comparáveis entre si são colocados em uma matriz e é feita uma avaliação comparando o grau de importância de um em relação ao outro conforme os pesos mostrados na Figura 14. Por exemplo, se ao se comparar o item $\mathrm{f} 1 \mathrm{com}$ o f2 for constatado que o f1 é mais importante que o f2, na posição X12 da matriz, será colocado o valor 5 e, na posição inversa, X21 da matriz será colocado o valor 1/5. Após a tabela ser completada, faz-se a média 
geométrica de cada linha. Em seguida, somam-se as médias geométricas e esta soma é colocada na última linha da coluna $\mathrm{Z}$ da matriz. Após, o peso de cada um deste fator e calculado na coluna $\mathrm{W}$, dividindo-se cada item da coluna $\mathrm{Z}$ pelo somatório de todos os itens da coluna Z.

\begin{tabular}{|c|c|c|c|c|c|c|}
\hline & $f_{1}$ & $\mathrm{f}_{2}$ & $\ldots$ & $f_{n}$ & $\mathbf{Z}$ & $\mathbf{W}$ \\
\hline$f_{1}$ & $\mathrm{X}_{11}$ & $\mathrm{X}_{12}$ & $\ldots$ & $X_{\text {ln }}$ & $\mathrm{Z}_{1}$ & W 1 \\
\hline$f_{2}$ & $\mathrm{X}_{21}$ & $\mathrm{X}_{22}$ & $\ldots$ & $X_{2 n}$ & $\mathrm{Z}_{2}$ & W 2 \\
\hline$\ldots$ & $\ldots$ & $\ldots$ & $\ldots$ & $\ldots$ & $\ldots$ & $\ldots$ \\
\hline $\mathbf{f}_{\mathbf{n}}$ & $\mathrm{X}_{\mathrm{n} 1}$ & $X_{n 2}$ & $\ldots$ & $\mathrm{X}_{\mathrm{nn}}$ & $\mathrm{Z}_{\mathrm{n}}$ & $\mathrm{W} \mathrm{n}$ \\
\hline \multicolumn{5}{|r|}{ Soma } & S & 1.0 \\
\hline
\end{tabular}

n Número de fatores

f $\quad$ Fator $\mathrm{i}$

$\mathrm{X}_{\mathrm{ij}}$ Resultado da avaliação das importâncias do fator $\mathrm{i}$ em relação ao fator $\mathrm{j}$ usando uma escala de importância de 1 (igualmente importante) a 9 (absolutamente importante). A matriz é completada pela inversão de $\mathrm{X}_{\mathrm{ji}}=1 / \mathrm{X}_{\mathrm{ij}}$;

\begin{tabular}{|l|c|}
\hline & Definição \\
\hline 1 & Igualmente importante \\
\hline 3 & Um Pouco Mais importante \\
\hline 5 & Mais importante \\
\hline 7 & Muito Mais importante \\
\hline 9 & Absolutamente importante \\
\hline
\end{tabular}

$\mathrm{Z}_{\mathrm{i}} \quad$ Média Geométrica dos pesos. $\mathrm{Z}_{\mathrm{i}}=\left(\mathrm{X}_{\mathrm{i} 1} * \mathrm{X}_{\mathrm{i} 2} * \ldots * \mathrm{X}_{\mathrm{in}}\right)^{1 / \mathrm{n}}$;

$\mathrm{S} \quad$ Somatório das médias geométricas $\mathrm{S}=\sum_{\mathrm{i}=1}^{\mathrm{n}} \mathrm{Z}_{\mathrm{i}}$;

$\mathrm{W}_{\mathrm{i}} \quad$ Peso do fator i. $\mathrm{W}_{\mathrm{i}}=\mathrm{Z}_{\mathrm{i}} / \mathrm{S}$;

Figura 14- Cálculo dos Pesos dos Fatores

Fonte: Adaptado de Olsen \& Ellram (1997)

A seguir, a Figura 15 apresenta um exemplo ilustrativo de cálculo dos pesos para os fatores. Este procedimento deve ser repetido para cada subcategoria da hierarquia. Como mostrado na Figura 15, o item Característica do produto é muito mais importante que o item Características Externas.

\begin{tabular}{|c|c|c|c|c|c|}
\hline & $\begin{array}{l}\text { Caracteristica } \\
\text { de Produto }\end{array}$ & $\begin{array}{l}\text { Caracteristica } \\
\text { do Mereado } \\
\text { Fornecedor }\end{array}$ & $\begin{array}{c}\text { Caracteristicas } \\
\text { Externas }\end{array}$ & $\begin{array}{l}\text { Média } \\
\text { Geométrica }\end{array}$ & Peso \\
\hline $\begin{array}{l}\text { Característica de } \\
\text { Produto }\end{array}$ & 1 & 3 & 7 & 2,76 & $67,74 \%$ \\
\hline $\begin{array}{c}\text { Característica do } \\
\text { Mercado } \\
\text { Fornecedor }\end{array}$ & $1 / 3$ & 1 & $7 / 3$ & 0,92 & $22,58 \%$ \\
\hline $\begin{array}{c}\text { Características } \\
\text { Externas }\end{array}$ & $1 / 7$ & $3 / 7$ & 1 & 0,39 & $9,68 \%$ \\
\hline
\end{tabular}

Figura 15- Ilustração do Cálculo dos Pesos de Cada Fator Fonte: Olsen \& Ellram (1997)

Calculado o peso de todos os fatores, o passo seguinte trata-se do cálculo do score ou pontuação em relação à dimensão analisada. Este cálculo da pontuação 
de uma determinada compra está ilustrado na Figura 16. Para este cálculo, utilizam-se os fatores determinados na Tabela 36. Para cada item do último nível analisado é feita uma ponderação utilizando o nível acima para se chegar a avaliação do primeiro nível. Conforme exposto na Figura 16, cada item ligado ao primeiro nível é ponderado de acordo com seu nível e, depois da ponderação ele é analisado conforme tabela 36 e ponderado novamente para que se consiga avaliar o item de primeiro nível. Alguns valores expressos podem ser entendidos como:

Peso de 0,54 para novidade indica que o fator tem uma representação 54\% na dimensão de Dificuldade de Gerenciar a Compra e o Fator Complexidade tem uma representação de $14 \%$ na Dimensão Dificuldade de Gerenciar a Compra. Somando-se estes valores encontramos a representação que o fator Característica do Produto tem na Dificuldade de gerenciar Compra (68\%).

Score de 5,80 (de 9), conforme tabela 36, indica que a compra possui uma dificuldade média no eixo de Dificuldade de Gerenciar a Compra.

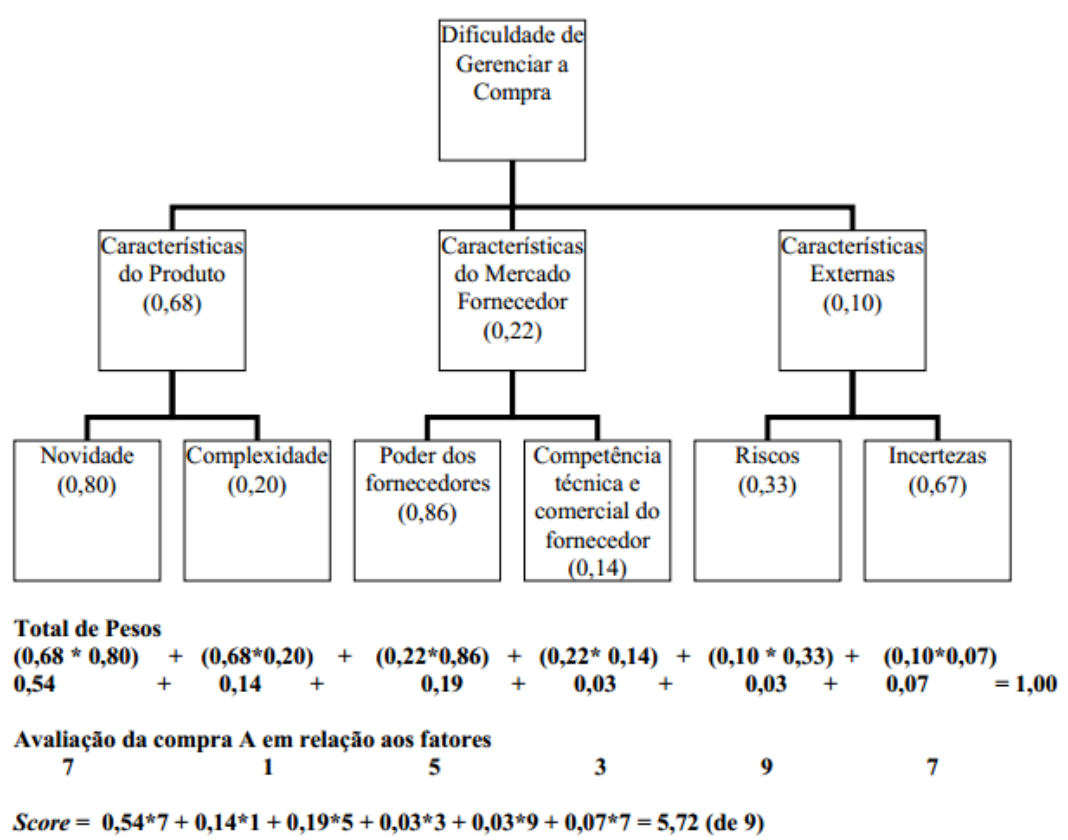

Figura 16- llustração do Cálculo do Score a Partir dos Pesos e Avaliação dos Fatores Fonte: Olsen \& Ellram (1997)

Tabela 35- Escala Determinada na Pesquisa para os Valores de Avaliação dos Itens Fonte: Adaptado de Olsen \& Ellram (1997)

\begin{tabular}{|l|c|}
\hline & Definição \\
\hline 1 & Importância Muito Baixa \\
\hline 3 & Importância Baixa \\
\hline 5 & Importância Moderada \\
\hline 7 & Importância Alta \\
\hline 9 & Importância Muito Alta \\
\hline
\end{tabular}

É importante que os gestores, envolvidos neste método, visualizem toda a escala apresentada na Tabela 35, quando forem avaliar cada compra. A escala é 
relativa e também possui um grau de subjetividade elevado na avaliação, portanto não se pode comparar empresas por meio deste método, trata-se de uma visão interna da empresa para que se possa destinar estratégias distintas a cada tipo de compra. Dada à subjetividade, é de grande valor que os gestores levantem números e informações de indicadores para que a avaliação seja menos vulnerável a erros. 


\section{Anexo 3- Modelo de Questionário}

Para os dois modelos, foram aplicados questionários com esta estrutura. Para não ficar repetitivo, foi colocado neste trabalho com o objetivo de exemplificação, somente o questionário aplicado no eixo horizontal do Modelo de Kraljic (1953).

\section{Contrato $\mathbf{n}^{\circ}$}

\section{Modelo de Kraljic (1953)}

- Parte 1- Perguntas (individual)

\section{Eixo Horizontal}

1) Especialização do Serviço

1.1 Existe grande tecnologia/complexidade envolvida na prestação de serviços da categoria de movimentação interna? Justificar

2) Disponibilidade no Mercado

2.1 Existe uma alta oferta no mercado para a prestação dos serviços solicitados? Justificar.

3) Custo da Mudança

3.1 Quais os custos de mudança do item por outro similar ou de um fornecedor atual para um novo fornecedor durante a vigência do contrato? Justificar.

4) Dependência Financeira

4.1 Qual o grau de dependência que os fornecedores que atendem a esta categoria têm da empresa XXX? Quanto em média à empresa representa no faturamento do fornecedor? Justificar.

5) Fornecedores Potenciais

5.1 Existem outros fornecedores em desenvolvimento para o fornecimento de itens já comprados pela empresa?

6) Competição na Procura

6.1 Os fornecedores são disputados por muitas empresas compradoras? 
- Parte 2- Comparação entre os Itens Analisados e Grau de Risco(em grupo)

Favor completar a tabela, utilizando os fatores abaixo, durante a discussão em conjunto com todo o grupo focal:

\begin{tabular}{|l|c|}
\hline & Definição \\
\hline 1 & Igualmente importante \\
\hline 3 & Um Pouco Mais importante \\
\hline 5 & Mais importante \\
\hline 7 & Muito Mais importante \\
\hline 9 & Absolutamente importante \\
\hline
\end{tabular}

Ex de preenchimento: se ao comparar o item $* 1$ (horizontal) com $0 * 2$ (vertical) o fator utilizado for 3, quando se comprar o $* 2$ (horizontal) com o *1 (vertical) o fator será $1 / 3$.

\begin{tabular}{|c|c|c|c|c|c|c|}
\hline & ${ }^{*} 1$ & *2 & ${ }^{*} 3$ & ${ }^{*} 4$ & ${ }^{*} 5$ & ${ }^{*} 6$ \\
\hline Especialização do serviço ( ${ }^{*} 1$ ) & 1,00 & & & & & \\
\hline Disponibilidade no mercado ( $\left.{ }^{*} 2\right)$ & & 1,00 & & & & \\
\hline Custo da mudança ( $\left.{ }^{*} 3\right)$ & & & 1,00 & & & \\
\hline Dependência Financeira $\left({ }^{*} 4\right)$ & & & & 1,00 & & \\
\hline Fornecedores Potenciais $\left({ }^{*} 5\right)$ & & & & & 1,00 & \\
\hline Competição na procura $\left({ }^{*} 6\right)$ & & & & & & 1,00 \\
\hline
\end{tabular}

Qual o risco associado a este item dentro da realidade da categoria de movimentação interna? Completar conforme discussão em grupo.

1) Especialização do Serviço:

2) Disponibilidade no Mercado:

3) Custo de Mudança:

4) Dependência Financeira:

5) Fornecedores Potenciais:

6) Competição na Procura: 
Tabela para avaliação do risco.

\begin{tabular}{|l|c|}
\hline & Definição \\
\hline 1 & Importância Muito Baixa \\
\hline 3 & Importância Baixa \\
\hline 5 & Importância Moderada \\
\hline 7 & Importância Alta \\
\hline 9 & Importância Muito Alta \\
\hline
\end{tabular}

